\title{
the economics of science and scholarship : an analysis of the Althoff system
}

Citation for published version (APA):

Vereeck, L. M. C. (1993). the economics of science and scholarship : an analysis of the Althoff system. [Doctoral Thesis, Maastricht University]. Datawyse / Universitaire Pers Maastricht. https://doi.org/10.26481/dis.19930204lv

Document status and date:

Published: 01/01/1993

DOI:

10.26481/dis.19930204lv

Document Version:

Publisher's PDF, also known as Version of record

\section{Please check the document version of this publication:}

- A submitted manuscript is the version of the article upon submission and before peer-review. There can be important differences between the submitted version and the official published version of record.

People interested in the research are advised to contact the author for the final version of the publication, or visit the DOI to the publisher's website.

- The final author version and the galley proof are versions of the publication after peer review.

- The final published version features the final layout of the paper including the volume, issue and page numbers.

Link to publication

\footnotetext{
General rights rights.

- You may freely distribute the URL identifying the publication in the public portal. please follow below link for the End User Agreement:

www.umlib.nl/taverne-license

Take down policy

If you believe that this document breaches copyright please contact us at:

repository@maastrichtuniversity.nl

providing details and we will investigate your claim.
}

Copyright and moral rights for the publications made accessible in the public portal are retained by the authors and/or other copyright owners and it is a condition of accessing publications that users recognise and abide by the legal requirements associated with these

- Users may download and print one copy of any publication from the public portal for the purpose of private study or research.

- You may not further distribute the material or use it for any profit-making activity or commercial gain

If the publication is distributed under the terms of Article $25 \mathrm{fa}$ of the Dutch Copyright Act, indicated by the "Taverne" license above, 


\section{THE ECONOMICS OF SCIENCE AND SCHOLARSHIP}

\section{An Analysis of the Althoff System}

DE WETENSCHAPSECONOMIE

Een studie van het Althoff systeem

DIE WIRTSCHAFTLICHE WISSENSCHAFTSFORSCHUNG

Eine Analyse des Systems Althoff 


\title{
THE ECONOMICS OF SCIENCE AIND SCHOLARSHIP
}

\author{
An Analysis of the Althoff System
}

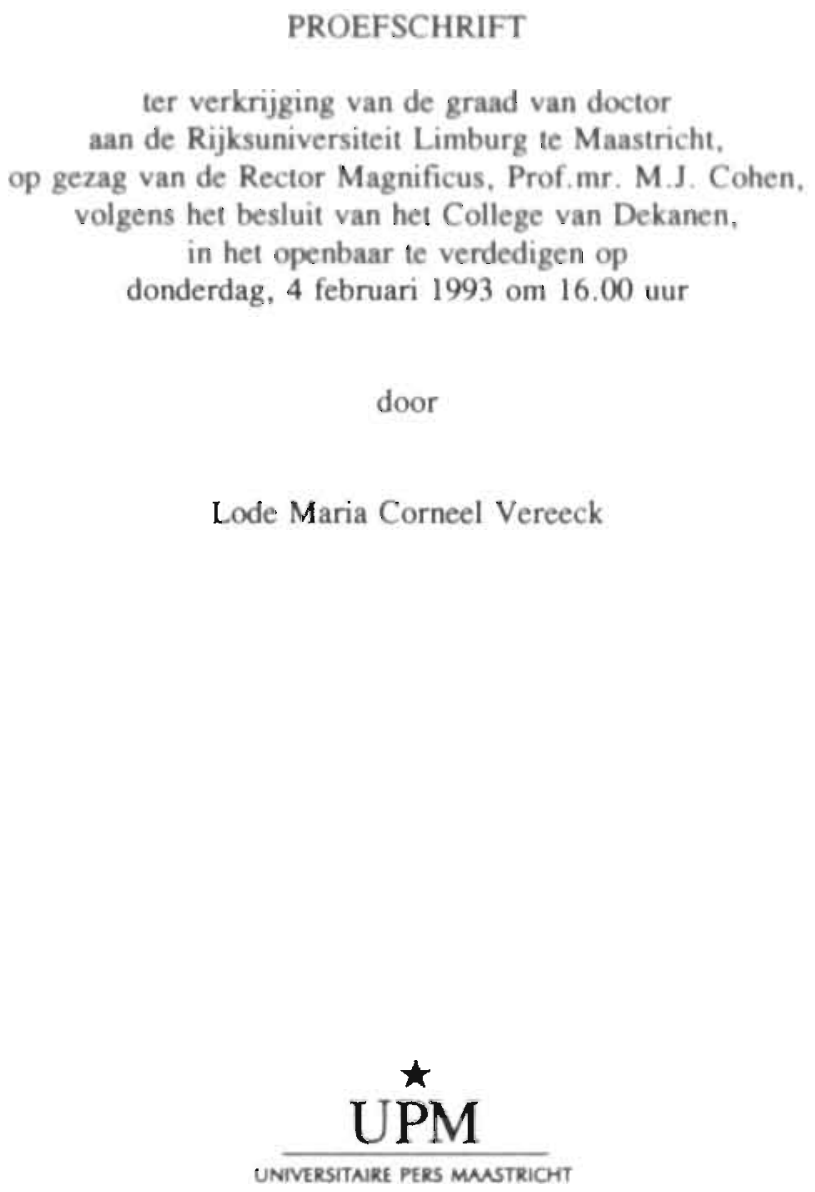


Promotor:

Co-promotor:

Beoordelingscommissie: Prof.dr. W.F.J. Buijink (voorzitter)

Prof.dr. W. Albeda.

Prof.dr. B.S. Frey (Univ. Zürich)

Prof.dr. T.L.C.M. Groot

ISBN 90-9005735-8

CopyręlM 1992, L.M.C. Vereeck. Masutnch

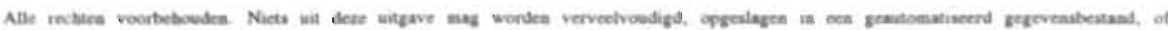

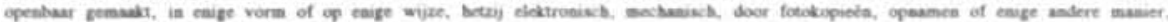
soader voonafgande achrifhetigke tocstemming van de uitgever

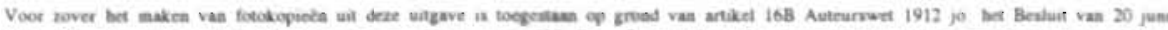

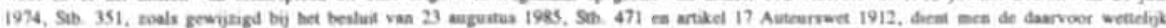

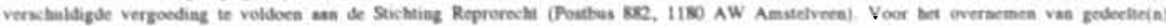

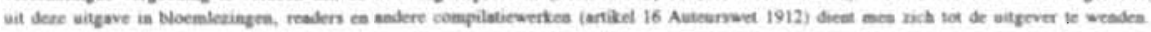

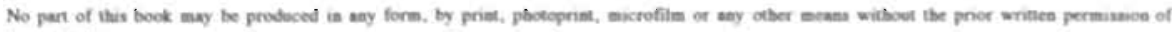
the polinher. 


\section{Contents}

Chapter 1: Introduction

Chapter 2: Method of Analysis

2.1. Economic Analysis

2.1.1. Economic Properties of Academic Knowledge 15

2.1.2. Standard Economic Theory on Academic Performance

2.1.3. New Institutional Economics

Chapter 3: Prussian Public Administration in the Second Empire 27

3.1. Life and Career of Friedrich Althoff (1839-1908) 29

3.2. Althoff's Administration 31

3.3. Organizational Structure of the Ministry of Culture 34

3.4. External Relations of the Ministry of Culture $\ldots 38$

3.4.1. Federal and Prussian Authorities 38

3.4.2. German Countries and Austria 39

3.4.3. Public Relations and Public Opinion 40 


\section{The economics}

of science and scholarship

an analysis of the Althoff system

L.M.C. Vereeck

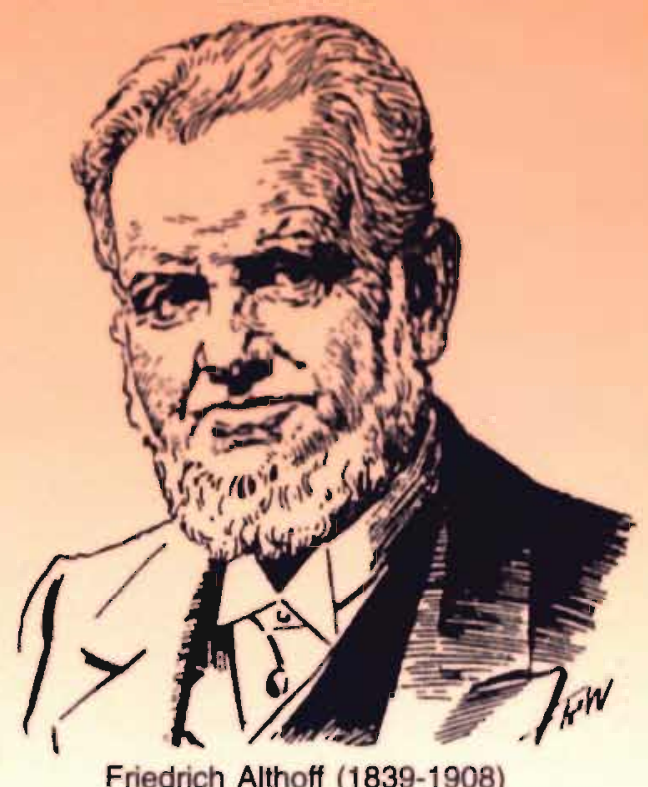

Friedrich Althoff (1839-1908)

Faculty of Economics and Business Administration University of Limburg

Maastricht

The Netherlands

Dissertation nr. 93 - 11 


\section{THE ECONOMICS OF SCIENCE AND SCHOLARSHIP}

\section{An Analysis of the Althoff System}

DE WETENSCHAPSECONOMIE

Een studie van het Althoff systeem

DIE WIRTSCHAFTLICHE WISSENSCHAFTSFORSCHUNG

Eine Analyse des Systems Althoff 


\title{
THE ECONOMICS OF SCIENCE AIND SCHOLARSHIP
}

\author{
An Analysis of the Althoff System
}

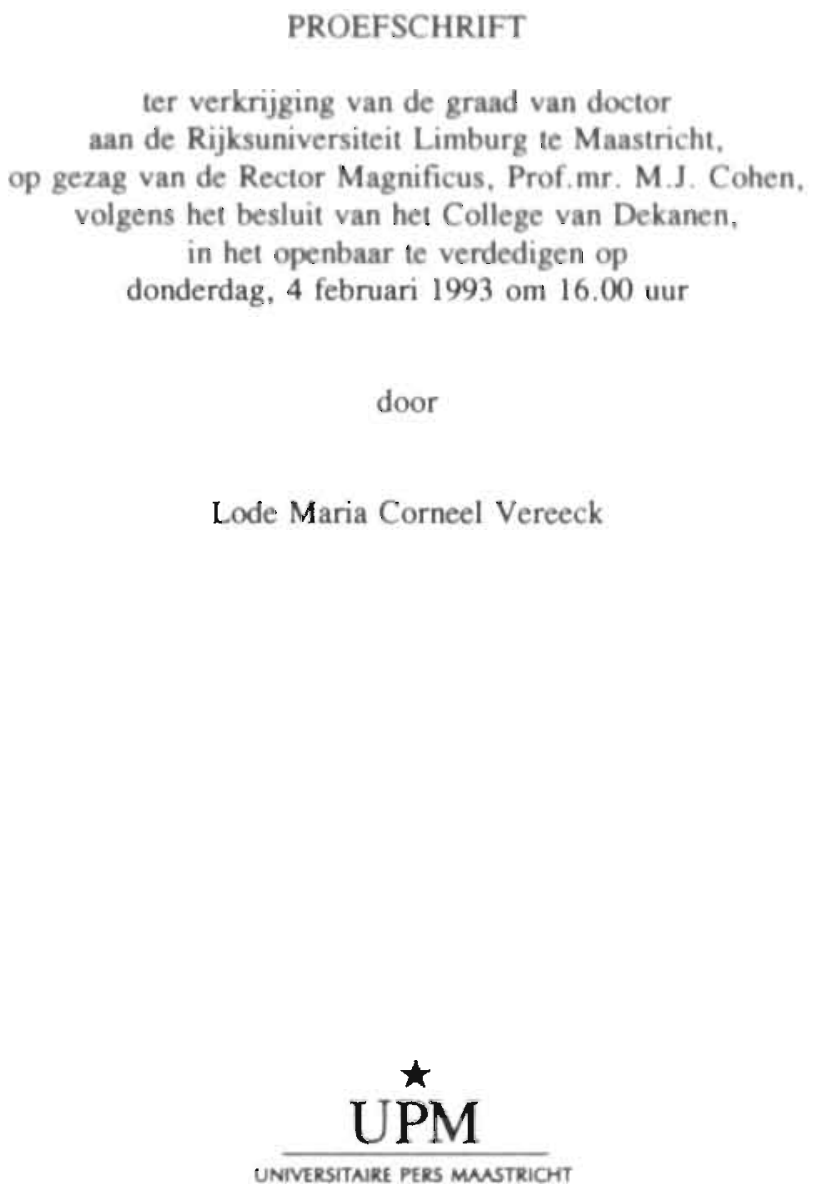


Promotor:

Co-promotor:

Beoordelingscommissie: Prof.dr. W.F.J. Buijink (voorzitter)

Prof.dr. W. Albeda.

Prof.dr. B.S. Frey (Univ. Zürich)

Prof.dr. T.L.C.M. Groot

ISBN 90-9005735-8

CopyręlM 1992, L.M.C. Vereeck. Masutnch

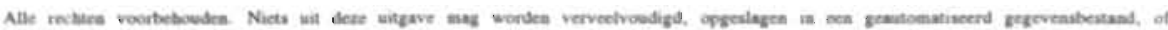

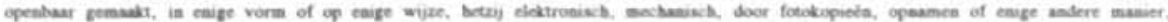
soader voonafgande achrifhetigke tocstemming van de uitgever

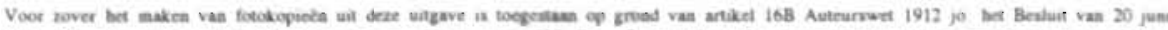

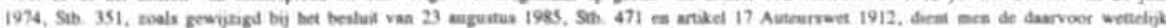

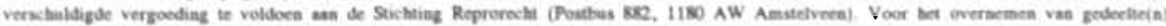

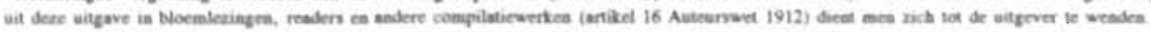

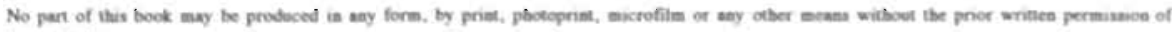
the polinher. 


\section{Contents}

Chapter 1: Introduction

Chapter 2: Method of Analysis

2.1. Economic Analysis

2.1.1. Economic Properties of Academic Knowledge 15

2.1.2. Standard Economic Theory on Academic Performance

2.1.3. New Institutional Economics

Chapter 3: Prussian Public Administration in the Second Empire 27

3.1. Life and Career of Friedrich Althoff (1839-1908) 29

3.2. Althoff's Administration 31

3.3. Organizational Structure of the Ministry of Culture 34

3.4. External Relations of the Ministry of Culture $\ldots 38$

3.4.1. Federal and Prussian Authorities 38

3.4.2. German Countries and Austria 39

3.4.3. Public Relations and Public Opinion 40 


\section{The economics}

of science and scholarship

an analysis of the Althoff system

L.M.C. Vereeck

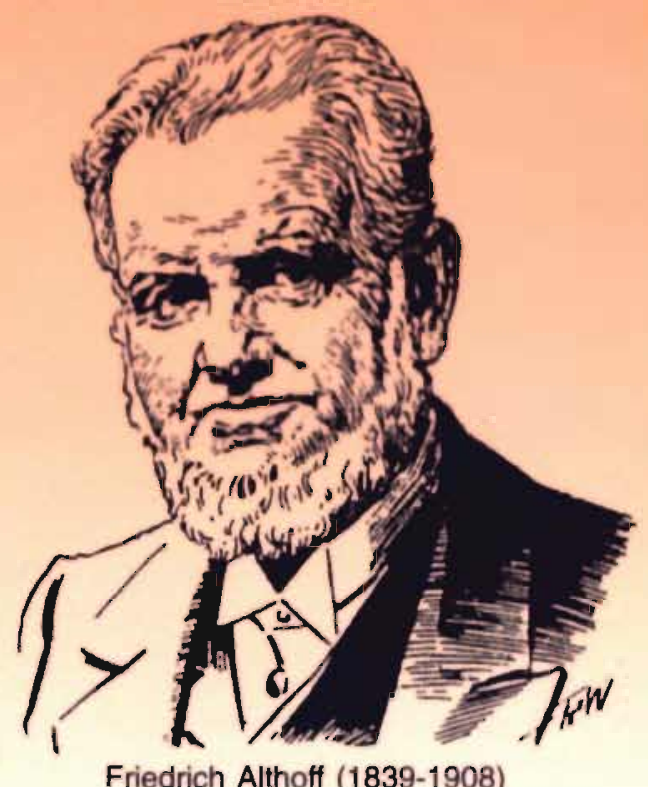

Friedrich Althoff (1839-1908)

Faculty of Economics and Business Administration University of Limburg

Maastricht

The Netherlands

Dissertation nr. 93 - 11 


\section{THE ECONOMICS OF SCIENCE AND SCHOLARSHIP}

\section{An Analysis of the Althoff System}

DE WETENSCHAPSECONOMIE

Een studie van het Althoff systeem

DIE WIRTSCHAFTLICHE WISSENSCHAFTSFORSCHUNG

Eine Analyse des Systems Althoff 


\title{
THE ECONOMICS OF SCIENCE AIND SCHOLARSHIP
}

\author{
An Analysis of the Althoff System
}

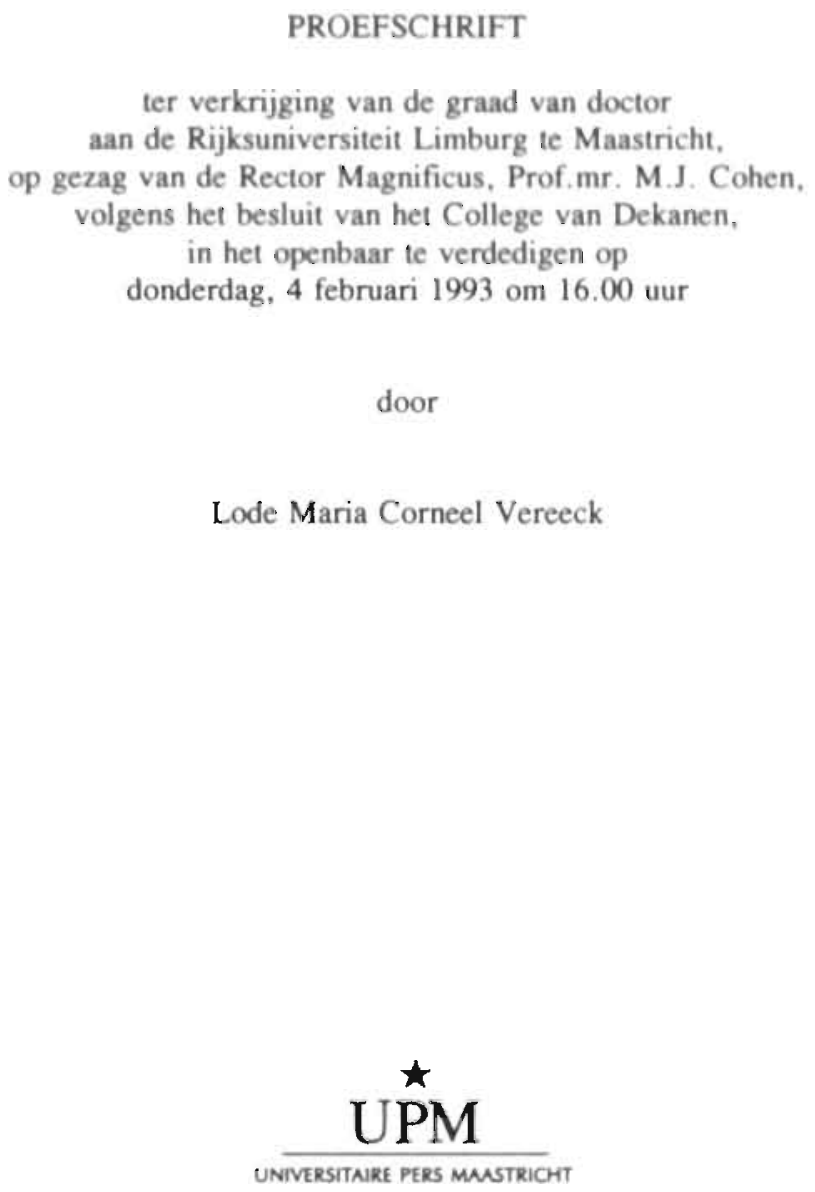


Promotor:

Co-promotor:

Beoordelingscommissie: Prof.dr. W.F.J. Buijink (voorzitter)

Prof.dr. W. Albeda.

Prof.dr. B.S. Frey (Univ. Zürich)

Prof.dr. T.L.C.M. Groot

ISBN 90-9005735-8

CopyręlM 1992, L.M.C. Vereeck. Masutnch

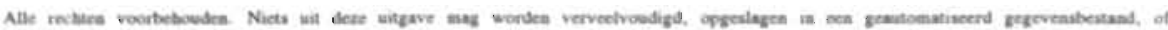

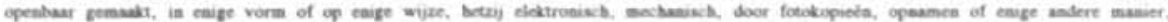
soader voonafgande achrifhetigke tocstemming van de uitgever

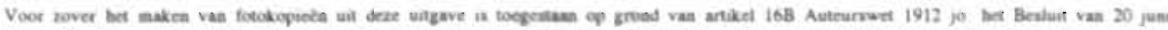

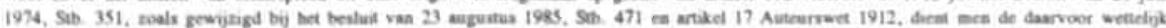

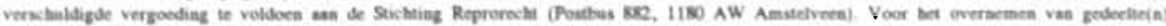

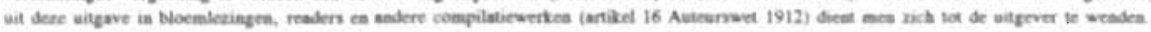

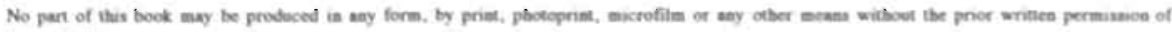
the polinher. 


\section{Contents}

Chapter 1: Introduction

Chapter 2: Method of Analysis

2.1. Economic Analysis

2.1.1. Economic Properties of Academic Knowledge 15

2.1.2. Standard Economic Theory on Academic Performance

2.1.3. New Institutional Economics

Chapter 3: Prussian Public Administration in the Second Empire 27

3.1. Life and Career of Friedrich Althoff (1839-1908) 29

3.2. Althoff's Administration 31

3.3. Organizational Structure of the Ministry of Culture 34

3.4. External Relations of the Ministry of Culture $\ldots 38$

3.4.1. Federal and Prussian Authorities 38

3.4.2. German Countries and Austria 39

3.4.3. Public Relations and Public Opinion 40 
Chapter 4: Growth and Institutional Reform of the Academic System

4.1. Humboldtian Principle

4.2. University of Straßburg, the Embryonic Althoff System 46

4.3. Growth of the Academic System

4.4. Althoff's Institutional Reforms and Innovations 51

4.4.1. Independent Research Institutes 51

4.4.2. Seminar Research Method 54

4.4.3. Professional Library System

4.4.4. University Regulations. 55

4.4.5. Academic Compensation 57

4.4.6. International Science Policy 58

Chapter 5. Methods and Means of the Althoff System

61

5.1. Academic Information

5.1.1. Academic Statistics

5.1.2. Network of Confidential Agents

$\ldots 63$

$\ldots 63$

5.2. Academic Appointments

5.2.1. Selection Procedure

5.2.2. Researchers of Genius

... 67

5.2.3. Minorities

$\ldots 71$

... 72

5.3. Academic Freedom

... 74

5.4. Financial Resources

... 75

5.4.1. Prussian Ministry of Finance

5.4.2. Local Authorities, Chambers of Commerce and Academies

5.4.3. Industry and Banking.

... 76

... 77

5.4.4. Private Foundations

... 78

5.4.5. Incentives to Finance Academic Research

... 78

... 80 
6.3.2. Principal-Agent Relations 98

6.3.3. Academic Organization $\ldots 9$

7.1.1. Cooptation Right

7.1.2. Selection of Candidates

7.1.3. Residual Claimancy

7.2. Academic Compensation

7.2.1. Implicit Contracts

7.2.2. Academic Salaries

7.2.3. Research Facilities and Prizes

7.2.4. Academic Tenure

7.2.5. Teaching and Research

\section{Chapter 8: Bureaucratic Governance}


Chapter 9: Conclusions

9.1. The Althoff System

9.2. Economics of Science and Scholarship

9.2.1. Science Policy

9.2.2. Economic Theory 161

References

Appendix

A. 1. List of Assumptions

... 177

A.2. List of Observations

$\ldots .178$

A.3. List of Propositions

$\ldots 180$

A.4. List of Hypotheses

183

A.5. List of Conclusions

Summary

185

Samenvatting

$\ldots 186$

Zusammenfassung 187

Acknowledgements

Curriculum Vitae 
1. Introduction 


\section{Introduction}

This study views the goal of science policy as that of creating an institutional environment in which science and scholarship can prosper. It is embedded in the Maastricht problem-oriented approach to research. The first purpose of the book is to understand the reasons for the outstanding performance of the Prussian-German academic system at the turn of the nineteenth into the twentieth century. By studying a true benchmark in the history of science administration, the so-called Althoff system,' the institutional conditions for productive academic activity are exposed. The task of the historical empirical analysis is to provide a solid base for economic theory. The economics of science and scholarship is an infant line of research, compared with the sociological and philosophical tradition of Popper, Kuhn, Lakatos and Merton." Therefore, this study makes an attempt to develop the theoretical framework, which models the relationship between the institutional structure in which academic production is being, carried out and the scientific performance of the scholars in question. The purpose is to understand the institutional requirements for productive academic research, the influence of institutional change on scholarly behavior and the conditions for an efficient allocation of academic resources. The important relation that exists between academic research and teaching and the performance of the economy makes it a relevant study of economic policy and applied public finance."

The organization of the book is as follows. Chapter 2 considers the method of analysis that underlies this study. It expresses a dissatisfaction with the standard economic performance analysis and stresses the importance of the new institutional economics for science and scholarship. The next three chapters are a survey of the Althoff system. Chapter 3 takes up the Prussian public bureaucracy as the engine of the German acadernic reform. It also emphasizes Althoff's specific style and position

I. The Althoff system is named after its originator, the German administrator of science Friedrich Althoff (1839-1908). While the Althoff system may not seem to be a system in the modern (American) sense of the word, this study claims that there is a "systematical" approach behind Althoff's science policy which allows its literal translation from German.

2. See: Karl R. Popper (1934), Logik der Forschung, Mohr, Tübingen, repr. (1976); Karl R. Popper (1963), Conjectures and Refutations: The Growth of Scientific Knowledge, Routledge and Kegan Paul, London; Thomas S. Kuhn (1962). The Structure of Scientific Revolutions, University of Chicago Press, Chicago, 2nd. ed (1970); Imre Lakatos and A. Musgrave (1970), Criticism and the Growth of Knowledge, Cambridge University Press, Cambridge; Robert K. Merton (1973), The Sociology of Science: Theoretical and Empirical Investigations, University of Chicago Press, Chicago.

3. The results of academic research and teaching are a potential source of innovations, which are the basis of productivity increases and economic growth. Although it is beyond dispute that the quality of the academic system affects the performance of an economy, the macro-economic effects are hard to model. While it can take years before the results of research are put into practical use, it can take decades before the education of a new generation leads to productivity increases as a result of better decision-making or improved production methods. See: Mark Blaug (1970), An Introduction to the Economics of Education, Penguin Books, Middlesex. 
in the administration. Chapter 4 traces the history of the Althoff system, in which the University of StraBburg played a pioneering role. More important, it deals with the measures that were taken to reform the Prussian academic system, some of which were boldly innovative. Chapter 5 looks at the methods of academic administration and illustrates the role of the scientific community in the Althoff system. The characteristic features of the Althoff system are summarized in a set of 33 observations to be used in the economic analysis.

Chapter 6 starts with an economic model of scholarly behavior, based on the seminal work by Gordon Tullock. "It stresses the vital role of the scientific community for. maintaining the quality of academic output. In the chapter, this theoretical framework is further developed, drawing upon the new institutional economics, namely transaction cost analysis and property rights theory. The extended model points out how academic institutions influence scholarly performance. Chapter 7 is concerned with the optimization of academic performance by means of institutional change. It deals, in particular, with academic appointments and compensation. The economic propositions, derived from the theory, are applied to the Althoff system in an effort to assess the efficiency of the Prussian academic system and the efficacy of Prussian science policy. Chapter 8 addresses the alleged (in)efficiency of academic bureaucracies. It also tries to explain Althoff's style and public entrepreneurship. Chapter 9 ends with the major conclusions, that can be drawn from the analysis. It assesses the performance of the Althoff system and the limits and opportunities of science policy, 40 propositions about science and scholarship, in general, and 15 hypotheses about the Althoff system, in particular, form the core of this study. They are listed in the appendix, along with the observations, the assumptions and the conclusions.

4. Gordon Tullock (1966), The Organization of Inquiry, Duke University Press, Durham N.C.. 


\section{Method of Analysis}

\subsection{Economic Analysis}

2.1.1. Economic Properties of Academic Knowledge

Assumption 1: Academic output is a public good, loaded with externalities.

Ass. 2: The economic properties of academic output make it very difficult to assess its value by means of quantitative indicators alone.

2.1.2. Standard Economic Theory on Academic Performance

2.1.3. New Institutional Economics

2.2. Historical Analysis 


\section{Method of Analysis}

How can an economic study about academic performance be set up in a theoretical way? What makes the Althoff system so well-suited for this line of research? This study takes a close look at the standard economic analysis, but favors a new institutional economic approach for the analysis of scholarly activity.

\subsection{Economic Analysis}

\subsubsection{Economic Properties of Academic Knowledge}

The economics of science and scholarship is generally not considered as an established field of research.

"Economists have not achieved a unified theory of the behavior of universities and scholars. Disagreements still occur over what is being maximized and what are the most significant constraints in the maximization. So, [.. I disagreements also still occur over what is the most efficient organizational form for universities to take. In science, as elsewhere, the key question remains how to allocate scarce resources. ${ }^{-5}$

Academic administrators allocate resources over various academic uses. For an efficient result, they necessarily have to assess the value of the different activities. Academic output is then maximized when the allocated resources equalize the benefits of the various academic activities at the margin. ${ }^{6}$ Since research is an activity aimed at discovering the unknown, it is extremely difficult to assess the expected returns on academic efforts and investments. Even the evaluation of new knowledge that has been actually produced and the measurement of academic performance remain difficult endeavors.

5. Arthur M. Diamond Jr. (1989). Economic Explanations of the Behavior of Universities and Scholars, Paper Annual Meeting of the North' American Economics and Finance Association, Atlanta, Georgia, p. 24.

6. The academic system is used in this study as a term to describe a set of institutions, in which scientific knowledge is produced and transmitted. Academic production consists of scientific research, teaching, academic management and public service. The emphasis in this book is on the organization of academic research and the process of scholarly production. 
"Doubtless, we must make some anticipations of future developments in science, as in other fields, if we wish to invest our resources wisely, but it should not be forgotten that they are guesses. Somehow the fact that these guesses are guesses about science seems to carry the implication that they themselves are scientific. In fact, the one area of human activity in which we have a good logical proof that it is not possible to foresee developments is science. We cannot know today what we will discover tomorrow. ${ }^{7}$

Assumption 1: Academic output is a public good, loaded with externalities.

Knowledge produced by academic research has the distinctive characteristics of a public good. Samuelson has pointed at the non-rivalry in the consumption of public goods and the principle of non-exclusion." By definition, a public good is a good that, if it goes to one individual, can be made available without additional cost to the members of the community. The second independent criterion is that it is also not feasible or profitable to exclude others from the enjoyment of that good. The consumption of knowledge by one individual does not affect the amount of knowledge, available for consumption to others. Knowledge generally is characterized by a zero marginal cost of serving another person. But under some conditions, it is feasible to exclude others from knowledge. For commercial reasons, applied research is often kept secret or patented. In essence, the patent system assigns temporary private property rights to a piece of knowledge. But the private appropriability ends when patents expire, which indicates that knowledge has latent public good properties. The temporary private ownership of knowledge acts as a private incentive to spur innovation first, but facilitates wide (public) use afterwards. ${ }^{8}$ Basic research and social science results, however, are genuine public goods, because practically nobody can be excluded from using them and because the non-rivalry argument also stands. Basic research is often unpatented because, by its very nature, the practical or commercial application is not of interest, nor immediately evident. There also exists no enforceable patent system for e.g. new management techniques or the rent-seeking. theory. They can be used freely. By design, the academic system produces public scientific knowledge, of which it is a recognized repository.

Academic research as well as instruction are loaded with externalities. An externality is defined as the economic gain or loss accruing to one or more recipient agents as the result of an economic action initiated by another agent with the gain or loss not being reflected in a market price. It is an unpaid, often unintended, side-effect of a producer's or consumer's output or input on other producers or consumers. A new theory or a new scientific instrument may create substantial external effects with respect to other research activities, thus influencing the performance of other scholars. Instruments developed for academic purposes often move to certain

7. Gordon Tullock (1966), Organizarion of Inquiry, p. 127.

8. Paul A. Samuelson (1954), "The Pure Theory of Public Expenditures", Review of Economics and Statistics 36, pp. 387-389.

9. Richard R. Nelson (1986), Institutions Supporting Technical Change in Industry, Research Paper, Yale University. 
industrial technologies. They create external benefits. The quality of the academic training of lawyers, managers, politicians, etc. determines their future ability to make just and efficient decisions, which influences the performance of the organization for which they work. It can also create substantial external benefits to the rest of the economy, which cannot easily be traced back to their academic education. The same argument holds for better management and production techniques, which are the result of academic research. The quality of engineering studies is an important determinant of the capacity of a nation to catch up with technological progress. Medical research and instruction affect the individuals who suffer from particular diseases. It also creates important external effects, because it is a determining factor of public health. Although an individual might never be ill himself, public health may affect the costs of the labor force he employs.

Consider the following example of the public good aspect and the external effects of academic output. The theory of rent-seeking ${ }^{10}$ is clearly a public good, because it is available for anyone who wants to make use of it without diminishing its availability to others. It may create substantial external benefits. A decision not to grant a monopoly license by a public administrator can be based upon his understanding of the welfare implications of rent-seeking. This decision-maker might have attended public choice classes, studied public choice publications, or been told about it. However, his decision affects many who are not part, and probably not even aware, of the decision that was taken.

Academic output can create negative externalities as well. Low-quality academic production can have serious consequences and mounting external costs. Poor teaching can lower the economic performance of a nation by way of a reduced transfer of skills or a diminished ability of students to take good decisions. Poor research productivity obviously retards scientific development, and also technological and economic progress.

The characteristics of public goods and externalities make it difficult to assess their value. " The non-purchasers of many public goods cannot practically be excluded from the consumption of the good. Consequently, they have an incentive not to reveal their true preferences, because they can enjoy the good without having to pay for its consumption. Only these free-riders know what the public good is worth for them. There is no price system that discloses their marginal willingness to pay. Furthermore, joint consumption implies that the public good is not divisible in separate units that can be easily counted, which complicates the measurement of actual consumption.

10. Rent-seeking is the activity that seeks to capture part of the social surplus, e.g. lobbying government to obtain a monopoly position.

11. Mancur Olson (1973), "Evaluating Performance in the Public Sector", in: Milton Moss (ed.). The Measurement of Economic and Social Performance, Studies in Income and Wealth 38. NBER, Columbia Univ. Press, New York, pp. 355-384. 
Private benefits and costs represent the internal effects of an economic action which do not escape the economic calculus of the initiating agent. Social benefits and costs represent both the internal effects and the external effects which escape the price mechanism. If social benefits exceed the private effects, a positive externality exists. An individual may produce less than the social optimal amount, because otherwise, he is adding benefits to society greater than the benefits for which he is being compensated. Of course, he may not always be aware of the externality, which he produces. The recipients of these benefits have a free-rider motivation not to pay for them voluntarily. Again, free-riding behavior may be intentional as well as unintentional. The external benefits and costs affect the social value of a good. In theory, it can be calculated who benefits how much or bears which costs from the external effect, but the chain of effects, as in academic research and education, is often. long and indirect. Therefore, the following assumption is made.

Assumption 2: The economic properties of academic output make it very difficult to assess its value by means of quantitative indicators alone.

Academic output is a public good, loaded with externalities. This implies that its economic value is difficult to assess, which in turn affects the administrator's ability to evaluate scientific output and measure academic performance in an objective way. When an academic administrator would want to evaluate academic productivity, he would theoretically have to find out who the marginal consumer is who makes use of the scientific insights, and then what this knowledge is worth to this marginal consumer. As pointed out, it is highly likely that he can not find this information. Moreover, the external effects of research and academic instruction are large, dispersed, diverse and difficult to capture. It is indeed very hard to measure the marginal contribution of scientific insights to economic welfare and further scientific progress.

The customers of the universities and academic research institutes are often ignorant about the academic product. Exactly therein lies the teaching mission. The same is true for research. The value of restilts in basic research is rarely appreciated until they have been applied. Since the value of research output and the quality of teaching services are difficult to measure, academic authorities, such as the Prussian Ministry of Culture, that monitor the production of academic output, have a dearth of the information needed to act efficiently. Administrations dealing with public goods and externalities know only their expenditures, and have no objective measure of the impact on the outputt volume these expenditures bring about, if any. If they do know what their organization produces, they would still have quite a problem to find out what it was worth to its consumers. The output of a research project that has failed to gain any results, let alone new insights, might prove very useful for other scientists, indicating which scientific lead they should not follow, although its proper production is close to nothing. 
Olson argues that there are no objective indicators for evaluating performance and efficiency of the public sector, in which he includes the academic system. ${ }^{12}$ This lack of information about the value of output, which is due to the typical function of the public administration to supply public goods or to control the production of goods with externalities, makes it difficult to run the public organization efficiently. To the extent that no-one can be excluded from the consumption of the good, the true preferences for the provision of the public good are difficult to establish. The condition of jointness of consumption implies that the marginal calculus breaks down and that measuring of outputs becomes infeasible. By their very nature, public sector activities involve the use or production of inputs or outputs of which the value is hard to measure. Given the tenuous relation between intended goals and measured outcomes, conclusions about policy or even a causal relation cannot be drawn casily.

\subsubsection{Standard Economic Theory on Academic Performance}

Nevertheless, economic scholars have tried to measure various aspects of academic performance. Mindful of the constraints and shortcomings of objective indicators, the following variables are often chosen as measures of teaching and research outcomes: the enrollment of undergraduates and foreign students, the graduation rates at the bachelor's, master's and doctoral level, the number of publications and citations and the number of Nobel Prize winners working in the organization when performing their prize-winning research. On the input side, the number of full, associate and assistant professors and the amount spent on maintenance, library activities and support expenditures are measured.

A count of scholarly publications indicates, for instance, the likelihood of the final goal, i.e. research that leads to increased knowledge and further scientific and economic advancement. However, if the number of publications is used as an indicator of academic performance, scholars are induced to publish the minimum publishable unit with little added scientific value. To counter this strategy the administrator could start counting the number of pages of their articles and books. This is a poor indicator of the scientific and economic value of academic efforts, however, because some scholars, who have produced only a few small articles, have revolutionized their discipline.

Therefore, some authors believe that citations are a better indication that the work of a scientist has been important to other scientists. According to Diamond, citations are a measure, if not of scientific merit, at least of scientific impact. ${ }^{13}$ Stigler and Friedland were one of the first to use citations as a measure of quality in economics. ${ }^{14}$ The advantages. and disadvantages of using citations as a measure of

12. Mancur Olson (1973), Evaluating Performance in the Public Sector, p 359.

13. Arthur M. Diamond Jr. (1988a), "The Empirical Progressiveness of the General Equilibrium Research Program", History of Political Economy 20, no. 1, pp. 119-135.

14. George J. Stigler and Claire Friedland (1975), "The Citation Practices of Doctorates in Economics", Journal of Political Economy 83, no. 3, pp. 477-507. 
quality have been discussed in the economic literature. ${ }^{15}$ If the value of the scientific output of scholars, is measured by means of citation count, it should be noted that, when successful scholarly work becomes a part of the corpus of science, its paternity is soon ignored. This absorption of old knowledge in current knowledge would support the efficient market model of scientific research. ${ }^{16}$ Adversely, scientists sometimes cite a paper, only to add an ambience of class and erudition, rather than because the cited paper has had any impact on their work. There may also emerge socalled citation cartels, in which authors cite friends in the profession for no other merit than their mutual friendship.

Another basic reason to cite is to increase the credibility of one's own work. ${ }^{17}$ In this respect, the works of authorities such as Nobel Prize winners are very popular. " Problems with citation counts clearly arise when the opinion of the author about the usefulness of the work quoted is lost in the count. Often the real impact is found to be through intermediaries, i.e. articles that cite articles that cite the original scientist's work. ${ }^{19}$ In general, citation counts do not measure the critical and innovative aspect of articles. The academic results of the scholars, who focus on social and policy problems or who are engaged in interdisciplinary research, are often used by members of another discipline..$^{20}$ Consequently, they are quoted in other journals than the traditional ones in their own profession, so that some citation counts tend to overlook them. The contribution of scholars who write survey articles may be exaggerated, however, if they tend to be more cited than the original work. Self-citations count as much as citation of others, although they are sometimes excluded from the count. ${ }^{21}$ While five to eight authors on one article is quite common, citation indices often only use the first name. The citation data used do not always discriminate between articles of the same author. Then again, productivity measured by the number of articles bears little relation to the value of these articles. Administrators should be aware that departmental loyalty is an important source of cited works, as is journal coaxing. Citation counts do not tell whether the cited author is on the editorial board of the journal in which he is cited, or whether it is merely standard practice to quote a scientist as probably the first to write on the subject. Stigler and Friedland also pointed at the decline in citations of non-journal and. foreign-language publications. In that case, citation count analysis is disadvantagous to

15. David N. Laband (1986), "Ârticle Popularity", Economic Inquiry 24, pp. 173-180.

16. Gary M. Anderson, David M. Levy and Robert D. Tollison (1989). "The Half-Life of Dead Economists", Canadian Journal of Economics 22, no. 1, pp. 174-183.

17. Brian L. Goff, William F. Shughart II, Robert. D. Tollison and Stephen B. Pociask (1987). "The Incentive to Cite", Journal of Institutional and Theoretical Economics 143, p. 467.

18. George J. Stigler and Claire Friedland (1979), "The Pattern of Citation Practices in Economics", History of Political Economy 11, no, 1, pp. 1-20.

19. Arthur M. Diamond Jr. (1988a), Empirical Progressiveness, p. 127.

20. Paul Davis and Gustav F. Papanek (1984), "Faculty Ratings of Major Economics Departments by Citations", American Economic Review 74, no. 1, pp. 225-230, and Dennis M. Gerrity and Richard B. McKenzie (1978), "The Ranking of Southern Economics Departments: New Criterion and Further Evidence", Southern Economic Journal 45, p. 610.

21. Michael C. Lovell (1973), "The Production of Economic Literature: An Interpretation", Journal of Economic Literature 11, p. 39. 
foreign scholars, who work in an academic system with a tradition to write books. There is alșo a considerable time-lag between the production of a paper and its publication as an article, let alone the citation of the work. This is particularly hard on young scholars, whose performance is analysed in this way. An administrator of science should therefore not use citation counts, when the lag between research completion and journal publication becomes too long, which might be the case for young scholars. Finally, departmental productivity, which is measured by the total and per capita number of citations, can be substantially altered when a major publisher moves to another university. ${ }^{22}$ Credit is mostly given to the institution at which a cited author is currently employed. The affiliation of a scholar to more than one institution makes it even harder to assign credit.

The difficulty of collecting quantitive information on final goals like the production and transfer of knowledge, leaves the standard economic analysis only with intermediate indicators of academic performance. ${ }^{23}$ Without further information, citation counts do not provide much useful information to the administrator about the value of the research output. Using the number of citations for administrative purposes may even induce scholars to start a citation cartel, which adds little to scientific knowledge. Nevertheless, citations counts can be useful in identifying which topics are currently under the most intense focus of research. ${ }^{24}$ Measurements such as graduation rates, while clearly imperfect, do hint at the level of the final outcome. However, they do not objectively measure teaching performance and should not be used as the basis for science policy. The number of enrollments and graduation rates can be easily augmented, e.g. by lowering the examination requirements. ${ }^{2 s}$ University or departmental teaching productivity should not be assessed by the number of graduates, but by its ability to graduate those students capable of obtaining a university degree.

22. David Colander (1989), "Research on the Economics Profession", Journal of Economic Perspectives 3, no. 4, p. 139.

23. Hogan is an illustrative example of how standard economic analysis is carried out. He ranked $\mathrm{Ph}$.D. programs in economics by using publications by former students as a measure of the quality of graduate teaching. He computed the number of pages published per Ph.D. graduate in three journals (AER, JPE, QJE) over a ten year period. The first objection would be that the number of pages is not a measure for the quality of the article. Secondly, it is not clear whether credit should be given to the institution where the doctoral education was received or to the institution to which the student went after completing the doctoral dissertation. It is not at all sure that the article can be considered the output of the department where the author wrote his doctoral dissertation. Timothy D. Hogan (1973), "Rankings of Ph.D. Programs in Economics and the Relative Publishing Performance of Their Ph.D.'s". Western Economic Journal 11, pp. 10-25.

24. Arthur M. Diamond Jr. (1989b), "Most-Cited Papers and Current Research Fronts", Current Contents 21, no. 2, pp. 3-8.

25. More generally, these measurements rely on the assumptions that the examination requirements at the different institutions are more or less the same, that the student population is homogeneous and that teaching is the primary determinant of the learning performances of students. 


\subsubsection{New Institutional Economics}

Two important conclusions come from the economic analysis so far. First, objective, quantitative indicators in statistical studies provide some indication about academic performance, but, for the reasons outlined, they have little value as science policy targets. Second, administrators of science, who need information about the value of academic output in order to allocate resources efficiently, have to combine quantitative and qualitative indicators. A major task of the science manager is to gather this information with a minimal waste of resources and to assure the objectivity of the qualitative information. The evaluation of academic performance is a complex matter involving the use of several indicators of performance and subjective judgements. The lack of value measures for academic output shifts the analysis from the subject of academic production to the design of the institutions in which scientists work and to which they adjust their actions.

The institutional structure affects the productivity of those working in it. As Douglass North points out, the institutional framework influences the choice options, the human interaction and the behavior of individuals. ${ }^{26}$ Institutional changes in the academic system are, therefore, likely to affect scholarly performance. Organizational change can reduce inefficiencies by inducing better performance, which does not always have to be measured to be observed. The matter of choosing an efficient organizational form is a type of constrained optimization problem. To each source of an information problem, there may be a different type of monitoring cost and institutional arrangement to resolve it. In this study, attention is given simultaneously to property rights, transaction costs and production costs. Insofar as there is interdependence among these factors, an appropriate balance has to be found with various possible trade-offs, e.g. by increasing monitoring costs, production costs may decrease, or, by improving incentives, monitoring costs may decrease. Despite the lack of accurate indicators of academic performance, the institutional framework can be subjected to economic analysis in order to improve the constraints-incentives system for scholars.

Institutions determine the content of property rights, production and transaction costs, which in turn affect the allocation and the use of resources in specific ways. ${ }^{27}$ They are the research subject of the new institutional economics. Each organizational structure is said to affect the incentives and constraints that influence economic behavior. Therefore, institutions are themselves regarded as legitimate objects of economic analysis. Institutions are particularly important in a complex environment of costly transactions and asymmetrical information, like the academic world of science and scholarship.

The new institutional economics attempts to explain the effect of specific institutions on the activities of economic agents and to point out the institutional requirements for

26. Douglass C. North (1990), Institutions, Institutional Change and Economic Performance, Cambridge University Press, Cambridge, p. 4.

27. Eirik Furubotn and Svetozar Pejovich (1972), "Property Rights and Economic. Theory", Journal of Economic Literature 10, no. 4, pp. 1137-1162. 
productive activity. The meaning of the term "new institutional economics" is broad, because the concept may include or exclude some of its subdisciplines. In this analysis, new institutional economics is used as a comprehensive term covering transaction cost analysis, property rights approach, and public choice theory of bureaucracy. The literature on transaction costs $^{20}$ and property rights ${ }^{29}$ is used to find an explanation for how the academic environment and the institutional innovations of the Althoff system influenced scholarly behavior and productivity. Public choice theories are used to study the Prussian bureaucracy.

\subsection{Historical Analysis}

Writing history is constructing a coherent story of some aspect of the human condition through time. For the economist, history serves an instrumental purpose. The use of historical data sharpens the analytical tools of economics. To assess the impact of institutional change on academic performance necessarily requires a long time horizon. The historical dimension of economics was essential in the research paradigm of the German Historical School. For Schmoller, ${ }^{30}$ the analysis would have had to start with an accurate description of the academic system in order to understand its performance. A realistic model would then have to explain the actual behavior of scholars from the history of the Althoff system. For economic analysis to have a practical purpose, it should be helpful in formulating economic policies. Besides the more instrumental purpose of the historical analysis, this study seems to fit nicely this modern outline of the Schmoller program. A historical case-study also has the practical advantage of no longer affecting the research subject. ${ }^{31}$ It obviously has to be well documented. If the case is generally conceived as an example of a successful science policy, the economist can also learn about the institutional conditions for optimal academic performance, from which he can draw conclusions for science policy.

28. Transaction cost literature stems from the article by Ronald H. Coase (1937). "The Nature of the Firm", in: The Firm, the Market and the Law (1988), University of Chicago Press, Chicago, pp. 33-56, and has found its most complete expression in Oliver E. Williamson (1985), The Economic Institutions of Capiralism, Free Press, New York.

29. Property rights literature stems from another article by R.H. Coase (1960), "The Problem of Social Cost", Journal of Law and Economics 3, pp. 1-44, and has been further developed by Armen A. Alchian and H. Demsetz (1972), "Production, Information Costs, and Economic Organization, American Economic Review 62, pp. 777-795. For a survey, see Eirik G. Furubotn and Svetozar Pejovich (1974), The Economics of Properry Rights, Ballinger. Cambridge, Mass..

30. See: Jürgen G. Backhaus (1989a), Gustav Schmoller and the Problems of Today, Working Paper 89.009 , University of Limburg. 24 pp.

31. Although science and scholarship is not considered an established theoretical field in economics and confidential information about the present academic organizations and the scholars who work there is not often available and reliable for analytical purposes, whatever result of such. a study may affect the financial position of an academic institution. In that case, possible errors concerning science policy implications can have an unwarranted and detrimental effect on academic performance. 
The Althoff system is uniquely suited for this line of research. Since the performance of scholars in the Althoff system is virtually undisputed, the reforms of the Prussian. academic system give evidence for these institutional requirements for productive academic activity. The case spans a period of 25 years and displays a large array of institutional innovations, which can be subjected to analytical study.

The Althoff system is also well documented. ${ }^{12}$ Althoff's extensive work archives are stored in the Central State Archives in Merseburg, Germany. ${ }^{33}$ His personal. documents are kept in the German State Library in Berlin. The Althoff system has been thoroughly investigated by German historians of science, in particular Bernhard vom Brocke from the University of Marburg and a whole team at the former EastGerman Academy of Science. Vom Brocke is considered the leading scholar in this field. ${ }^{34}$ Since it is not intended to make a contribution to the history of science, the analysis relies mainly, but not entirely, on these secondary sources. In 1989, two conferences were set up to commemorate Althoff's 150th birthday. In June, the Institute for Theory, History and Organization of Science held a conference in East

32. The Althoff literature is almost exclusively in German. With the exception of some references (see e.g. John E. Craig (1984), Scholarship and Nation Building, Chicago University Press, Chicago), only one survey article of the Althoff system is currently available in English: Bernhard vom Brocke (199la), "Friedrich Althoff: A Great Figure in Higher Education Policy in Germany", Minerva 29, no. 3, pp. 269-293. The papers and proceedings, of the Heilbronn conference will be published in English as well in: Jürgen G. Backhaus (1993), ed., The Economics of Science Policy, forthcoming.

33. Department II, Rep. 92.

34. Bernhard vom Brocke published several articles and books on the Althoff system. Bernhard vom Brocke (1980), "Hochschul- und Wissenschaftspolitik in Preußen und im Deutschen Kaiserreich 1882-1907: das 'System Althoff", in: Peter Baumgart (Hrsg.), Bildungspolitik in Preußen zur Zeit des Kaiserreichs, Arbeitsgemeinschaft zur Preußischen Geschichte e.V., Band I, Klett-Gotta, Stuttgart, pp. 7-119; (1981a), "PreuBische Bildungspolitik. 1700-1930", Abhandlungen, 1./15', pp. 727-746; (1981b), "PreuBische Bildungspolitik von Gottfried Wilhelm Leibniz und Wilhẹm von Humboldt bis Friedrich Althoff und Carl Heinrich Becker (1700-1930)", in: W. Bōhme (Hrsg.), Preuben - eine Herausforderung, Karlsruhe (Herrenalber. Texte, 32), pp. 54-99; (198Ic), "Der deutsch-amerikanische Professorenaustausch. Preußische Wissenschaftspolitik, internationale Wissenschaftsbeziehungen und, die Anfänge einer deutschen auswärtigen Kulturpolitik vor dem Ersten Weltkrieg", Zeitschrift fur Kulturaustausch, Institut für Auslandsbeziehungen, Stuttgart, no. 31, pp. 128-182; (1985), "'Diẹ Getehrten". Auf dem Weg zu einer vergleichenden Sozialgeschichte europãischer Bildungssysteme und Bildungseliten im Industriezeitalter", Jahrbuch des italienisch-deutschen historischen Institurs in Trient, Societa editrice il Mulino, Bologna, pp. 389-401; (1987), "Friedrich Althoff", in: Wolfgang Treue und Karlfried Gründer (Hrsg.), Berlinische Lebensbilder Wissenschaftspolitik in Berlin. Minister, Beamte, Ratgeber, Colloquium Verlag, Berlin, pp. 195-214; (1988), "Von der Wissenschaftsverwaltung zur Wissenschaftspolitik: Friedrich Althoff (19.2.1839-20.10.1908)" Berichte zur Wissenschaftsgeschichte, VCB Verlagsgesellschaft, Weinheim, no. 11, pp. 1-26; (1989a), "Vorgeschichte, Gründung und Entwicklung der Kaiser-Wilhelm-Gesellschaft zur Förderung der Wissenschaften - Der Anteil Friedrich Althoffs", in: I.T.W., Friedrich Althoff 1839-1908, Akademie der Wissenschaften der DDR, Berlin, pp. 129-163. He edited (1990) Forschung im Spannungsfeld won Politik und Gesellschaft, Deutsche Verlagsanstalt, Stuttgart (with Rudolf Vierhaus) and (1991b), Wissenschaftsgeschichte und Wissenschaftspolitik im Industriezeitalter. Das "System Althoff" in historischer Perspektive, Verlag August Lax, Hildesheim. 
Berlin. One month later, the second conference took place in Heilbronn with an international audience of historians, sociologists and economists. A third conference was held in Bad Homburg in May 1990. As a result of these research efforts, the Althoff system is nowadays very well documented.

Althoff did not write a document in which he explained the general idea or rationale behind the academic reforms.

"Es gibt - soweit bisher bekannt - kein umfassendes Reformprogramm aus Althoff's Feder [..]. Althoff war Praktiker, kein Theoretiker. Das 'System Althoff' ist aus jahrzehntelanger Praxis heraus entstanden. ${ }^{\text {as }}$

"Soweit bisher bekannt, hat er (Althoff) das Bild der Wissenschaft, das seinem wissenschaftspolitischen System zugrunde lag, nirgends systematisch ausgefithrt; es muß aus seinen Handeln erschlossen werden, mit allen Unsicherheiten, die solcher Rekonstruktion eigen sind. ${ }^{*}$

The tryptich by Vom Brocke is, therefore, a most useful lead to start the investigation.

"Wenn im folgenden vom 'System Althoff' gesprochen wird, dann soll darunter ein Dreifaches verstanden werden: der systematische Ausbau des Hochschulwesens zum. zentral organisierten und gelenkien 'Großbetrieb' im Zeichen der Weltgeltung. deutscher Wissenschaft I..l; die damit notwendig verbundene Burokratisierung. aber auch die gouvernemental-autoritär-patriarchalische Lenkung des Hochschulwesens, die Eingriffe staatlicher Burokratie in die Hochschulautonomie nicht scheute (..): der Versuch eines genialen, freilich auch herrischen Barokraten und Kulturpolitikers (Althoff) die Tradition der Wissenschaftspflege des liberalen preußischen Kulturstaates fortzufuhren und die Freiheit von Forschung und Lehre und ein freies und tolerantes Klima an den Hochschulen zu verteidigen [.. J. "37?

The expanding, academic system was managed by the Prussian. central state administration in Berlin. It strived for the international recognition of German science and scholarship. The enterprising and liberal head of the Prussian Ministry of Culture was Althoff. ${ }^{38}$ In the following three chapters, attention is paid to the impact of Althoff. on Prussian science policy, to the state bureaucracy that implemented the policy measures, and to the measures themselves that changed the academic institutions in an effort to improve scientific performance.

35. Bernhard vom Brocke (1980), "Hochschul- und Wissenschaftspolitik in Preußen und im Deutschen Kaiserreich 1882-1908: Das 'System Althoff", in: Peter Baumgart (Hrsg.). Bildungspolitik in Preufen zur Zeir des Kaiserreichs, Klett-Cotta, Stuttgart, p. 49.

36. Hubert Laitko (1989), "Alexander yon Humboldt und Friedrich Althoff: Zur Tradition selektiver Wissenschaftssteuerung durch Förderung: von Hochbegabungen", in: I.T.W., Friedrich Althoff 1839-1908, Akademie der Wissenschaften der DDR, Berfin, p. 3.

37. Bernhard vom Brocke (1980), Hochschul- und Wissenschaftspolitik, pp. 15-16.

38. Liberal meaning defending the basic rights of freedom, among' which academic freedom, freedom of speech and freedom of religion. 


\section{Prussian Public Administration in the Second Empire}

3.1. Life and Career of Friedrich Althoff (1839-1908)

Observation 1: Althoff was the leading public administrator of science in Germany for a quarter of a century.

\subsection{Althoff's Administration}

Obs. 2: Althoff's "personal regime" is characterized by an autonomous and autocratic working style, a strong personal administration and independent professionalism.

Obs. 3: Althoff had excellent contacts with the Imperial Court and obtained the exceptional right of direct address to the Emperor.

Obs. 4: The international recognition of German science and scholarship was a major objective of the Althoff system.

\subsection{Organizational Structure of the Ministry of Culture}

Obs. 5: The Prussian Ministry of Culture was organized as a typical hierarchical bureaucracy.

Obs. 6: Althoff could rely on a professional staff of experts in his department.

Obs. 7: Althoff operated beyond the formal limits of the authority invested in him. 


\subsection{External Relations of the Ministry of Culture}

3.4.1. Federal and Prussian Authorities

Obs. 8: The Ministry of Culture coordinated the initiatives in the field of science and education in Prussia.

\subsubsection{German Countries and Austria}

Obs. 9: Prussia determined the science policy of Germany.

Obs. 10: The Austrian university system had the special mission to integrate the different peoples of the Austrian-Hungarian, Empire.

3.4.3. Public Relations and Public Opinion

Obs. 11: Althoff used many media to promote the policy and the achievements of his department. 


\section{Prussian Public Administration in the Second Empire}

\subsection{Life and Career of Friedrich Althoff (1839-1908)}

Friedrich Theodor Althoff was born on February 19, 1839 in Dinslaken near Wesel in the province of Niederrhein, Prussia. He was the son of the Domain Councillor Friedrich Theodor Althoff and his father's second wife, Julie von Buggenhagen. His father's family included state officials and parsons. On his mother's side, he was of Pomerian noble descent and related to Prussian Minister of War, Julius Ernst von Buggenhagen. His father died in 1852 at the age of 54. Young Althoff was raised by his mother, who was 37 when she had her only child. His marriage with Marie Ingenohl in 1864 was stable, but remained childless. Sixty-nine years old, Althoff died in Berlin-Steglitz on October 20, 1908. Marie Althoff, his wife, outlived him by seventeen years. ${ }^{39}$

After High School, Althoff went to the University of Bonn to study Law (1856-1861). He started his career as an interrogating magistrate and lawyer (Auskultator und Referendar) at several Rhenish courts and at the Superior Court of Justice in Berlin (1864-1866). After Althoff passed the government examination of counsellor (Assessor), he practised law in Ehrenbreitstein. During the French-German War "he was a member of the nursing staff. In September 1870, when the war was over "he returned to Bonn, where he continued the legal practice for only a short period of time. During one year, he also occupied himself with scientific legal research in order to obtain a license as a private lecturer in law.

In 1871, Althoff accepted the offer to become a legal adviser (Justitiar und Referent) in the Committee for Religious and School Affairs in Straßburg, previously called the Civil Commissioner's Office. This position would form the start of his career in the administration of science. He stayed in the Alsatian public administration for eleven years until 1882. Althoff was responsible for the infrastructure and the appointment of the academic staff at the University of Straßburg, which had just reopened its doors . Being a jurist, he was also asked to write the application and incorporation charter of this new German University.

Althoff combined his administrative duties with an Extraordinary Professorship of French and Modern Civil Law at the University of Straßburg. His only scholarly

39. See: Manfred Nebelin, (1990), "Friedrich Althoff, in: Kurt G.A. Jeserich and Helmut Neuhaus (Hrsg.), Personlichkeiten der deutschen Verwalfung. Blographien zur Ver. walrungsgeschichte 1648-1945, Kohlhammer-Verlag. Stuttgart, pp. 426-429. 
achievement in cooperation with other jurists was the comprehensive compilation of all laws valid in Alsace-Lorraine, including the French regulations that had not been repealed. The work was done in such an exemplary way that it ended the legal uncertainty in the region. Althoff was offered a full professorship in 1880, although he had not finished the doctoral dissertation, which he had agreed upon with professor Rudolph von Gneist (Berlin) in 1863. Therefore, he refused, despite the substantial salary increase coming with the promotion. ${ }^{40}$

1882 meant the real start for the Althoff system. In that year, Althoff received a call and appointment from the Prussian Ministry of Culture in Berlin (Kultusministerium). His office was located Unter den Linden 4, at the corner with Wilhelmstraße. He started as a referendary (vortragender Rat) ${ }^{41}$ and was asked to administer the appointments of the academic staff working at all the Prussian universities and academic institutes. ${ }^{2}$ In spite of Althoff's formal position and his official duties, he soon expanded his activities into all areas of science policy. He occupied himself with the financial management and institutional reform of the Prussian academic system. In 1897. Althoff was promoted to Assistant Secretary (Ministerialdirektor). ${ }^{43}$ By that time, he had become the leading public official for cultural and scientific affairs. He. was offered positions in the government as. Secretary of Culture (1899) and Minister of Culture (1906). On both occasions, he declined the offer.

In 1907, he was awarded a life-long position in the Upper Chamber and was nominated Crown Counsellor. Never enobled, Althoff received five Honorary Doctor's degrees. ${ }^{4}$ One foreign university, Harvard University, gave Althoff an Honorary Doctor's degree of Law on June 17, 1906. He was the fourth German to receive this honor. ${ }^{45}$ Althoff also became an honorary member of the academies of Berlin (1900), Göttingen (1901) and. Erfurt (1904). He resigned from office in 1907 for reasons of ill health. Earlier requests on account of his health were withdrawn under pressure of the pleas by Minister of Culture Konrad Studt (1838-1921).

40. In the 1880 's, a full professor was paid a salary of 2200 . Taler per year $( \pm 66,000$ DM or $\pm 38,000$ USS current value); an extraordinary professor earned 1600 Taler $( \pm 48,000 \mathrm{DM}$ or. $\pm 27,500$ USS).

41. A referendary was, an official, charged with specific duties. The term was used as a title.

42. The Prussian academic system was organized and sponsored by the state and managed by the state administration. Professors were appointed, and paid by the Ministry of Culture. Until Althoff arrived, the appointment of the academic staff had been handled according to the following standard procedure. The facuity that had a professorship vacant was asked by the Ministry to suggest candidates in a rank order. Most of the time, the advice was followed and the faculty's candidate appointed, making the approval by the Ministry a mere formality.

43. The term has also been translated as "Director" [See: John E. Craig (1984)] or "Departmental Director" [See: Bernhard vom B'rocke (1991)].

44. Dr.h.c. Straßburg in 1882, Dr.med.h.c. Marburg 1890, Dr.rer.pol.h.c. Münster in 1905 , Dr.jur.h.c. Harvard in 1906, Dr.Ing.h.c. Technische Hochschule Berlin-Charlottenburg in 1907.

45. The three previous degrees had been awarded to the jurist K.J.A. Mittermaier from Heidelberg (1836), German ambassador to the USA Theodor von Holleben (1838-1913) in 1901 and prince Heinrich from Prussia (1862-1929) in 1902. 
Observation 1: Althoff was the leading public administrator of science in Germany for a quarter of a century.

From 1882 till 1907, Althoff was the leading public official for academic affairs in Germany. He incorporated the continuity of the state administration and protected the academic system from political interferences. Due to his strong, personal administration and autocratic working style, the Prussian academic system and science policy were labeled as the "Althoff system".

\subsection{Althoff's Administration}

Althoff's working style was remarkable, to say the least. Along with his motives, it is worth a closer look. His character and working style are incisively described by his biographer, Bernhard vom Brocke. ${ }^{40}$ The qualitative characteristics of Althoffs administrative style are also well documented. Vom Brocke typifies Althoff as energetic, efficacious, autonomous and autocratic.

He certainly was a hard worker, who regularly worked sixteen hours a day. Even after his retirement, he kept receiving guests for work meetings about science policy issues. He invited them to his retreat (the Schierke sanatorium in the Harz Mountains) and to his house in Berlin, even the day before he died. Autocratically, he refused to appoint candidates proposed by faculty when he suspected nepotism or biased behavior. This inspired much of the controversy over the "almighty" Althoff.

Observation 2: Althoffs "personal regime" is characterized by an autonomous and autocratic working style, a strong personal administration and independent professionalism.

From 1882 till 1897, Althoff was one of the thirty-three referendaries who worked in the Ministry of Culture. At the next hierarchical level stood four Assistant Secretaries. They were the highest ranked bureaucrats and received their instructions directly from their superior in the government, namely the Minister of Culture. Althoff was promoted to this position in 1897.

It should be noted that Althoff was not in the formal position to shape the science policy of Prussia.. A referendary had to execute the instructions received from the Assistant Secretary. The latter was supposed to implement the measures taken by the Minister of Culture, while sharing powers with three other Assistant Secretaries. However, Althoff designed the entire science policy, manipulating his superiors and interfering in other departments of the Ministry. This autonomous style and autocratic approach contrasted with his formal position in the hierarchy and was referred to as Althoff's "personal regime".

46. See: Bernhard vom Brocke (1980), Hochschul- und Wissenschaftspolitik, pp, 33-35 and pp. 4347. 
"He (Althoff) was usually depicted as a [... tyrant, who absolutely bossed the whole university system of Prussia. That he was the real head of that system is certain, and that he was a statesmanlike and in every way a competent head, seemed to me clear; but he was without any of those evil qualities which are so often charged against him. ${ }^{-17}$

"Die Autorität mit der Althoff sein Amt ausabte, 1.. / war selbst für das autoritär regierte Preußen ein einmaliger Fall. Ebenso einmalig war sein Verständnis für die Belange der Wissenschaft. Letzeres bezieht sich in besonderem Maße auf den von Althoff entscheidend mitbewirkten materiellen, personellen und institutionellen Ausbau des preußischen Wissenschaftssystems. In der Ära Althoff kam es zu einer bis dahin beispiellosen qualitativen und quantitativen Entwicklung des Wissenschaftspotentials in Preußen. ${ }^{\text {to }}$

Observation 3: Althoff had excellent contacts with the Imperial Court and obtained the exceptional right of direct address to the Emperor.

From the end of the nineties, Althoff had acquired the right of direct address to the Emperor, Wilhelm II. ${ }^{49}$ Normally, such a meeting required the mediation of a member of government. Althoff's direct contact was quite unusual for a civil servant and reinforced the "personal regime". In these conversations with the Emperor, Althoff tried to gain support for his projects. He discussed e.g the "Dahlem" project with the Emperor. Dahlem was a large estate, just outside Berlin, where Althoff wanted to set up research institutes. In Dahlem, outstanding scholars would be free of teaching obligations and could devote their efforts solely to research. Althoff's talks were successful: the Emperor preserved 100 hectares of the estate for state research institutes.

Althoff was never part of the official suite, but he had excellent contacts with the Imperial Court. The Emperor's public support of international exchange professorships conșiderably helped Althoff's international science policy. The Empress agreed to preside over the organizations concerned with the progress of medicine which Althoff had set up..$^{50} \mathrm{He}$ was also asked to take care of the education of the Crown Prince. ${ }^{51}$

47. Nicholas Murray Butler (1940) Across The Busy Years: Recollections and Reflections, Charles Scribner's Sons, New York, vol. 2, p. 71. Nicolas Butler (1862-1947) was President of Columbia University, New York, (1901-1945) and winner of the Nobel Peace Prize.

48. Ralph-Jürgen Lischke, (1989), "Friedrich Althoff und die preußisch-deutsche Wissenschaftspolitik, in: 1.T.W., Friedrich Althoff 1839-1908, Akademie der Wissenschaften der DDR, Berlin, p. 19.

49. Wilhelm II (1859-1941), Emperor of Germany and King of Prussia (1888-1918).

50. For example, the "Empress Auguste Victoria Institute for the Battle Agaist Infant Mortality in Germany", founded in 1906 in Berlin and the "Empress Friedrich Institute for Postgraduate Education in Medicine"

51. Althoff was also a friend of Georg Hinzpeter (1827-1907), who had been the tutor of the ruling Emperor Wilhelm II. 
The Court's support protected Althoff and his career against undue attacks from politicians, professors, university administrators and rival bureaucrats. John Craig has argued that Althoff seriously considered leaving the Ministry of Culture only once, when he came under attack in late 1901 during the Spahn controversy. "That he chose to remain in office was largely due to the tributes he received from men prominent in academic and political circles. Of these tributes, the one that most impressed Althoff, was a Christmas card from the Emperor on which a brief inscription was written:

"The worst fruits are not the ones at which the wasps nibble. ${ }^{-53}$

It should be noted that Althoff resigned or threatened to resign on two other

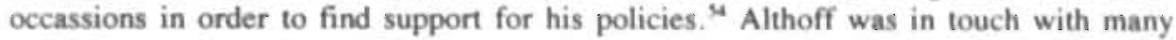
politicians and members of Parliament. He never associated himself with a particular political party or movement. Influential politicians became his confidential advisers. Among them, captain-of-industry and maecenas Henry Böttinger (1848-1920).

Observation 4: The international recognition of German science and scholarship was a major objective of the Althoff system.

At the turn of the century, the spirit of the time was pervaded by feelings of national pride. Competition between the nations included science as well, because scientific progress was considered an important factor in achieving technical superiority and economic prosperity. The international recognition of German science and scholarship (Weltgeltung deutscher Wissenschaft) was a major goal of the Prussian state and a driving force of Althoff's administration.

Whether and how this aim was realized, is studied in the next chapters. But when Althoff received his Honorary Doctor's degree, Harvard's President Charles W. Eliot (1834-1906) paid tribute in his speech to Althoff, acknowledging specifically his efforts. for the international recognition of German science and scholarship.

52. Althoff had created a confessional chair for a catholic scholar at the University of Straßburg. This decision infuriated the Protestant scientific community.

53. John E. Craig (1984), Scholarship and Nation Building, p. 159

54. Althoff threatened to resign three times, hoping to resolve or end some serious disputes. In 1891, he resigned officially for reasons of overwork. In fact, his resignation was due to a dragging school reform and unresolved disputes with the Minister of Finance. Althoff received a call to the University of Bonn as a full. professor, but the appoinment never came about. The Minister of Culture urged him to stay in. Berlin and continue. In 1895, Althoff's threats forced the Minister of Finance to provide funds necessary for the construction of a second State Hospital for Pediatrics in Breslau. As mentioned by Craig. Althoff was heavily critized for the Spahn case. He thought of clearing up the incident by resigning from office. The Stralburg faculty rejected the appointment of the 26-year old Spahn, not because he was too young or unqualified, but because he occupied a confessional chair. It created a big row throughout the German (Protestant) scientific community. The Emperor, however, backed Althoff and refused his resignation. 


\subsection{Organizational Structure of the Ministry of Culture}

The: Prussian state had a long tradition of organizing public education and sponsoring artistic and scientific activity. The state's interest in the education of its citizens was legally embedded in the Allgemeines Landrecht fur die Preußischen Staaten, which was promulgated in 1794 .

"Schulen und Universitäten sind Veranstaltungen des Staates, welche' den Unterricht der Jugend in natzlichen Kenntnissen und Wissenschaften zur Absicht haben. Dergleichen Anstalten sollen nur mit Vorwissen und Genehmigung des Staates errichtet werden. " (2. Teil, 12. Titel, \$ 1 und 2)

The tradition begins with the first King of Prussia, Friedrich I (1657-1713). In 1694, he founded the Friedrich-University in Halle as well as the "Academy of Arts for the Promotion of Architecture, Sculpture and Painting" in Berlin. Eight. years later, the King created the Societat der Sciencien, which was called later the Royal Prussian Academy of Science." In 1717, his son, and successor, Friedrich Wilhelm I (16881740), introduced compulsory school attendance for children. To put this policy into effect, the King opened approximately 2,000 schools during his reign. While Prussia took the lead, the measure was soon followed by Saxony in 1724. Other countries followed much later. ${ }^{56}$ At the Universities of Halle and Frankfurt am. Oder, Friedrich Wilhelm created the first chairs for economics and public administration. The Charite-Hospital, that was built in 1726, made Berlin a leading European center for medical education.

The public administration of the academic system started in 1808, when the Prussian Ministry of the Interior set up a small department for Culture and Public Education (Sektion für den Kultus und Offentlichen Unterricht). This bureau would form the basis for the Ministry of Religious, Educational and Medical Affairs, that became an independent administration in 1817 (Ministerium der geistlichen, Unterrichts- und Medizinalangelegenheiten). The Ministry was referred to as the Ministry of Culture (Kultusministerium) or ironically as the Ministry of the Mind (Ministerium des Geistes). The start of the public administration virtually coincided with the foundation of the University of Berlin by Wilhelm von Humboldt (1767-1835). ${ }^{57}$ The basic idea of a research university was adopted by the whole system of German language universities. Scholarly research was considered an essential part of the function of professors. ${ }^{58}$

55. Bernhard vom Brocke (1981a), "Preußische Bildungspolitik 1700-1930", Abhandlungen 1./15., p. 728.

56. Austria in 1774, Bavaria in 1802, Baden in 1803, Scotland in 1872, France in 1882 and the Soviet-Union in 1930.

57. The University of Berlin was founded in 1810 during the reign (1797-1840) of Friedrich Wilhelm III (1770-1840).

58. Joseph Ben-David (1971), The Scientist's Role in Society, University of Chicago Press, Chicago, p. 108. 
The new Prussian Ministry consisted of three departments: (1) the Department of Religious Affairs, (2) the Department of Education and (3) the Department of Medicine. The second department was split into two bureaus: the Department for Science, Arts and Higher Education, which was called Unterrichtsabteilung $I$ (U1). and the Department for Elementary Education (U2). The Department of Higher Education was divided into four subdepartments in 1909. The Ministry of Culture was the largest state administration in terms of the share of the national budget." Like the rest of the Prussian state bureaucracy, the organizational structure was a pyramidal hierarchy.

Observation 5: The Prussian Ministry of Culture was organized as a typical hierarchical bureaucracy.

The organizational structure of the Prussian Ministry of Culture shows the typical pyramidal form of bureaucracy. The formal head was the King of Prussia. ${ }^{\infty} \mathrm{He}$ was a constitutional monarch and the head of government, whose authority was restricted by the rules of the parliamentary system. The government consisted of several Ministers, among whom was the Minister of Culture, and was led by a Prime Minister. ${ }^{61}$ A Minister was assisted by a Secretary. They were the political superiors of the bureaucrats working in the public administration.

At the top of each department stood an Assistant Secretary, who was the highest ranked civil servant. The four departments in the Ministry of Culture were directed by four Assistant Secretaries, who each had their own responsibility. ${ }^{62}$ Issues overlapping the authority of two or more departments went back up the hierarchy to the Minister, who was ultimately responsible. The Assistant Secretaries worked with. a. staff of referendaries, who were assigned to more specified duties. ${ }^{\text {s }}$ Thirty-three referendaries worked in the Ministry of Culture and their number hardly changed during Althoff's career. The number of lower clerks, however, rose from 43 to 82 . The Ministry in Berlin set up twelve provincial committees for secondary education, which were presided by the Governors, (Oberprasident). In thirty-five districts, local school departments were in charge of primary education, while school inspectors informed Berlin about the actual situation of the educational system. From a modern perspective, it was a relatively small bureaucracy.

The Department for Science, Arts and Higher Education was responsible for the public administration and management of all Prussian universities, academic institutes, libraries, museums and schools. Prussia had ten universities (Berlin, Greifswald,

59. See observation 14 .

60. After the unification of the German states in 1871, the King of Prussia was also Emperor of Germany.

61. Other ministerial responsibilities were Public Finance, Agriculture, Justice, Commerce and. Trade, Internal Affairs and War.

62. From 1897 till 1907, Althoff was Assistant Secretary of the Department for Science, Arts and Higher Education (U1).

63. As a referendary in U1 (1882-1897), Althoff was responsible for the appointment of the academic staff at Prussian universities and academic institutes. 
Marburg, Königsberg, Kiel, Halle, Göttingen, Breslau, Bonn and Mūnster) and five technical colleges with university status (Berlin-Charlottenburg, Aachen, Hannover, Danzig and Breslau). Until 1879, the latter had been part of the Ministry of Commerce, which stayed involved in the new business schools of Köln, Frankfurt and Berlin created between 1901 and 1918. The business schools were partly financed by local authorities and chambers of commerce. ${ }^{44}$

U1 was also responsible for independent research institutes that were not affiliated to a university or academy of science. ${ }^{\circ 5}$ Its responsibilities included eight scientific institutes in Berlin, including the Academy of Science, ${ }^{6 /}$ four Royal Prussian Academies of Art (Berlin, Konnigsberg, Cassel and Düsseldorf) and the art schools. The Department also managed eleven museums, among which was the Ethnographic Museum in Berlin. It ran nine pedagogic seminars (Berlin, Königsberg, Danzig. Posen, Breslau, Magdeburg, Mũnster, Cassel, Koblenz) and the Berlin Gymnastic Teachers Institute. The reorganization of the Charite-Hospital in Berlin was also carried out by Althoff's department. A new task was the Information Bureau for Higher Education in Germany and Abroad. Finally, the department was regularly asked by other Prussian authorities to form expert commitees on different issues.

Observation 6: Althoff could rely on a professional staff of experts in his department.

Althoff always operated from within the Prussian state bureaucracy. In his department, he could rely on a team of loyal staff members, many of whom he had attracted to the department himself. Some of them, like Arnold Sachse (1857-1933) and Otto Natumann (1852-1925), came from Straßburg, where Althoff had noted their qualities. Althoff had a team of hard-working, professional administrators. Prussian discipline made civil servants work hard, Althoff being a key example. Most of the referendaries, who worked in his department were academics and held a doctoral degree. Naumann, Ernst Eilsberger (1858-1947) and Friedrich Schmidt-Ott (18601956) e.g. were jurists. Above all, Althoff attracted good managers to the public administration. ${ }^{67}$

64. Manfred Rasch. (1990), "Thesen zur preußischen Wissenschaftspolitik gegen Ende des Wilhelminischen Zeitalters", Berichte zur Wissenschaftsgeschichte, VCB Verlagsgesellschaft 12, Weinheim, p. 249, ftn. 4 .

65. For example: the Biological Institute and North Sea Museum on Helgoland, the Royal Experimental Institute for the Quality and Drainage of Water, the Institute for Infectious Diseases led by Robert Koch, the Royal Institute for Experimental Therapy Frankfurt directed by Paul Ehrlich and the Royal Institute for Hygiene in Posen.

66. The Royal Library, the Royal Observatory, the new Royal Astronomical Calculation Institute, the new Royal Botanic Garden in Dahlem, the Geodesic Institute near Potsdam, the new Royal Meteorological Institute, the new Royal Aeronautical. Observatory in Lindenberg, the Astrophysical Observatory near Potsdam.

67. After the death of Althoff, some staff members assumed management positions in the private sector. In their work with Althoff, they had acquired genuine international experience and organizational skills. Eilsberger and Schmidt-Ort. received offers from large chemical enterprises. The former went to Solvay-Werke AG in Bernburg to become president. After a 
The referendaries were assigned specific duties. Althoff was responsible for universities and academic personnel (1882-1897). After his promotion, he was succeeded by the economist Ludwig Elster (1853-1935). In spite of Elster, Althoff stayed in charge of the professorial appointments in Prussia, which was the core policy of the system. "The independent research institutes, the academies, the libraries, exchange professorships and examination procedures were the responsibility of Schmidt-Ott and Eilsberger. The historian Wilhelm Wehrenpfennig (1829-1900) was in charge of the technical colleges. Naumann succeeded him in 1899. He was also responsible for the budget and academic infrastructure (buildings, ete.). The art schools were administered by Max Jordan until 1896. Then, the archeologist Richard Schöne (1840-1922) took over. Together with the historian of art Wilhelm von Bode (1845-1929), he was repsonsible for the Prussian musea. The Prussian high school system was managed by Adolph Matthias (1847-1917) until 1900. His successor Karl Reinhardt (1849-1923) later became an important school reformer. The business schools were administered in cooperation with the Ministry of Commerce and Trade.

The first personal assistant (Hilfsarbeiter) of Althoff was Sachse," $\mathrm{He}$ was succeeded by the brilliant Schmidt-Ott. Then came Alfred Tilmann and Eilsberger. Althoff's last assistant was Ernst von Hülsen.

Althoff was on friendly terms with his predecessor Hermann Lucanus (1831-1908). He had worked for almost thirty years until 1890 in the Ministry of Culture. Lucanus had been an Assistant Secretary and Secretary of Culture at the end of his career. Althoff paid regular visits to discuss policy issues with Lucanus, who had acquired a large expertise in the academic affairs.

Althoff could rely on staff of hard-working experts, who prepared his policy measures. Taking this into consideration, the term "Althoff system" may seem to give too much credit to a single man in the Prussian bureaucracy. But as Max Klatt asserted:

"[Die Althoffschen Reformen], zwar oft von anderen Männern vorbereitet, sind schließlich doch allein durch Althoffs machtvolles Eingreifen herbei gefuhr worden. $" 70$

Observation 7: Althoff operated beyond the formal limits of the authority invested in him.

67. ...

one-year mandate as Minister of Culture (1917-1918), the latter was appointed president of Leverkusen's Bayer and member of the board of directors of IG Farben AG.

68. See observation 26 .

69. Sachse wrote a biography of Althoff: Arnold Sachse (1928), Friedrich Althoff und sein Werk, Berlin, $150 \mathrm{pp}$.

70. Quoted in: Bernhard vom Brocke (1980), Hochschul- und Wissenschaftspolitik, p. 43. 
In 1882, Althoff started as one of thirty-three referendaries. His main duties included the appointment of academic staff. In 1897. Althoff rose to the position of Assistant Secretary, of whom there were four. It has been noted that Althoff was not in the formal position to shape the science policy of Prussia. A referendary had to execute the orders from and render account to the Assistant Secretary, who himself received instructions from the Minister of Culture. Hierarchically "the Assistant Secretaries were each others equals. So were the referendaries.

Even as a referendary, Althoff was the leading public official for academic affairs and took measures in all areas of science policy. He set out the entire science policy, manipulating his superiors and equals and interfering in other departments. $\mathrm{He}$ violated the typical tenets of hierarchical organizations such as top-down decision making, pyramidal span of control and non-interference in equal hierarchical levels.

Althoff manipulated all the Ministers of Culture, who just followed his orders." Konrad Studt, who was the most loyal in executing Althoff's academic reforms, once made his remaining in office dependent on Althoff's stay. Althoff interfered in the other departments of the Ministry of Cuiture as well. Since he was appointed Chairman of the Scientific Deputation of Medicine in 1900, Althoff was responsible for medical science. In practice, this meant that the department for medicine received its instructions from Althoff. He was asked by the Empress and the Women's Movement to reorganize the education of girls. ${ }^{n}$ However, the department U2 was in charge of the schools for girls. For Althoff to carry out the reorganization, meant operating jeyond the limits of his authority and interfering directly in another department. As a referendary, Althoff launched academic reforms in areas for which other referendaries were responsible. For example, the establishment of new research institutes and libraries, the budget and the creation of an innovative financing system.

\subsection{External Relations of the Ministry of Culture}

\subsubsection{Federal and Prussian Authorities}

Observation 8: The Ministry of Culture coordinated the initiatives in the field of science and education in Prussia.

After the German unification in 1871, scientific and educational affairs remained entirely the full responsibility of the member states, that had insisted on their cultural independence. Although the German Empire was involved in culture and science, there was no central authority or federal Ministry of Culture. Due to the dominant position of Prussia, however, there was a considerable influence on the direction of the science policy of the other German countries. The Prussian Ministry of Culture functioned as a leading coordinator in science policy issues.

71. Gustav yon Goßler (1881-1891), Robert Graf von Zedlitz-Trützschler (1891-1892), Robert Bosse (1892-1899), Konrad Studt (1899-1907), Ludwig Holle (1907-1909).

72. As a final result in. 1908 , German women were also allowed to study at Prussian universities. 
Nevertheless, the federal government took some initiatives in science and education. The Chancellory of the Empire or a federal Ministry had to cooperate with the state in which the project was set up. A fine example is the Seminar for Eastern Languages. at the University of Berlin, which was administered by the Prussian Ministry of Culture and financed by the federal Ministry of Foreign Affairs. Established in 1887. it was of particular importance for the language training of German diplomats. In a reconciliatory gesture towards the new German territories, the German Empire had. reopened the University of StraBburg in Alsace-Lorraine in $1872 .^{n}$ Althoffs personal commitment in its foundation established a permanent influence of the Prussian Ministry in the Alsatian university.

Other Prussian authorities. were involved in educational matters as well. The Prussian Parliament and the Ministry of Finance determined the budget and the annual expenditures of the Ministry of Culture. The Ministry of Commerce and Trade co-financed the business schools and the agricultural, sylvicultural and veterinary institutes. New examination procedures for lawyers required the advice of the Ministry of Justice. All activities were coordinated by the Ministry of Culture. Only the military education. system was administered independently by the Ministry of War.

Private initiatives were also centrally coordinated. Large municipalities and Chambers of Commerce e.g. could set up research institutes or even a university. Frankfurt a.M. was the first privately endowed university in Prussia. Although it was a private initiative, it was carefully planned by Althoff, Prussia's leading public official, and Frankfurt's mayor, Franz Adickes (1846-1915). Private funds from industry and banks played a singularly important role in the creation of independent state research institutes in Dahlem. The project reached its conclusion after Althoff's death with the creation of the Kaiser-Wilhelm-Gesellschaft, later called the Max-Planck-Institute. ${ }^{74}$

\subsubsection{German Countries and Austria}

Observation 9: Prussia determined the science policy of Germany,

After the unification, the Second German Empire (1871-1918) included seven states. ${ }^{75}$ Prussia was the largest state. It covered two thirds of the territory of the Empire and was the home of sixty percent of the German population. ${ }^{76}$ Due to its dominant position, Prussia had always had a considerable influence on the other countries. In the area of science policy, however, the states were completely sovereign. In the Althoff era, all major academic innovations were introduced by Prussia. The

\section{Reichsuniversităt Straßbburg.}

74. Bernhard vom Brocke (1989a), "Vorgeschichte, Gründung und Entwicklung der KaiserWilhelm-Gesellschaft zur Förderung der Wissenschaften - Der Anteil Friedrich Althoffs": in: I.T.W., Friedrich Althoff 1839-1908, Akademie der Wissenschaften der DDR, Berlin, pp. 129163.

75. Bayern, Baden, Mecklenburg, Preußlen, Sachsen, Thüringen, Wúrttemberg.

76. The population in Prussia grew from 26 million in 1882 to 37 million in 1907, while the German population increased from 4I million (1882) to 63 million (1907). 
scientific progress in the Althoff system forced the other countries to follow Prussia and to adopt part of Althoff's policy.

Nevertheless, there remained considerable competition between the German states. The Universities of Heidelberg (Baden) and München (Bayern) were famous institutions, that competed with Berlin and Göttingen for professors and for reputation. But, there was also cooperation. Althoff was in close contact with his colleagues in the other states, like e.g. Franz Böhm (1861-1915) in Baden. The latter was probably not as influential, but certainly as inventive as Althoff. ${ }^{7}{ }^{\text {In } 1898 \text {, }}$ Althoff organized a conference on university affairs for German and Austrian officials. The meeting was intended to exchange experiences and to surmount the negative aspects of cultural sovereignty. ${ }^{7 /}$ At the conference, mostly administrative problems were discussed. Although the agreements only had an informal character, policy became better coordinated. Reacting against the cooperation of the state administrators, the universities organized a special Rektorenkonferenz and a lecture: s' conference, known as the professorial union.

Observation 10: The Austrian university system had the special mission to integrate the different peoples of the Austrian-Hungarian Empire.

In Austria, it was believed that higher education would surmount conflicts and promote the integration of the nations in the Austrian-Hungarian Empire. ${ }^{79}$ The Austrian university system consisted of two parts: the German and the non-German speaking universities. The influence of German scholarship increased the conflict between these two groups, especially when the German speaking universities realized that, compared with the universities in Germany, they were behind in development. Germany was considered to be the ideal model, which increased the political pressure on the Ministry of Culture in Vienna.

A chair in Vienna was considered as the peak of the academic career in Austria. Höflechner argues that scholars themselves did no longer consider the University of Vienna their ultimate goal because they had to perform too many different tasks: at the Academy of Science, in special institutes or as consultants. ${ }^{80}$ Disappointed about the lack of time that was left over to pursue research, they began to turn down calls from Vienna and went to Germany. This seemed an incredible reaction to the officials in the Austrian Ministry of Culture. When Austrian professors became civil servants in 1898, they were deprived of their income from lecture fees, which was not compensated by the average salary increase. Especially at the University of Vienna,

77. Bohm convinced the Grand Duke of Baden to support e.g. the Institute for Experimental Cancer Research to allow the Heidelberg Director of the Surgical Clinic, Vinzenz Czerny (1842-1916), to continue his path-breaking cancer research.

78. This had been painfully illustrated by the unsuccessful attempt to reform the requirements and procedures for a doctor's degree in Germany. Also see observation 19.

79. The Emperor of Austria, Franz Joseph 1 (1830-1916), had become King, of Hungary in 1867.

80. Walter Hoflechner (1989), The Impacr of the Prussian and German Universiry Administrations on the Austrian University System Berween 1875 and 1914. Paper Althoff Conference, Heilbronn, p. 9. 
the very high numbers of students had meant very high incomes. Another incentive for professors coming from. smaller universities in Germany and Austria to accept an appointment to Vienna was now lacking. Compensation required substantial extra payments, which were not given very often. The Ministry of Culture could only sustain salary increases with the agreement of the Ministry of Finance.

\subsubsection{Public Relations and Public Opinion}

Observation 11: Althoff used many media to promote the policy and the achievements of his department.

Althoff was the commissioner spokesman of the government in Parliament (Regierungskommissar). He took the floor 150 times to present and defend the policy of the Ministry of Culture. All his speeches were thoroughly prepared, but the most famous became his address on February 23, 1905 about the history of academic freedom.

Althoff launched several press campaigns to create the support of public opinion. The monthly "International Report on Higher Education" was the most suitable medium to spread an idea among academics. It was distributed freely to every professor in Germany, Austria and Switzerland. ${ }^{81}$ In order to reach a broader audience, Althoff used the daily Allgemeine Zeirung, which was published by August Scherl (1849. 1921). ${ }^{2}$ The weekly cultural and scientific addendum of the Allgemeine Zeitung was an influential magazine. Therefore, Althoff carefully introduced his plans in this newspaper. Later, this press medium was replaced by Althoff's own weekly Internationale Wochenzeitschrift für Wissenschaft, Kunst und Technik.

81. Hochschulnachrichten. Monatsabersicht aber das gesamte Hochschulwesen des In- und Auslandes was published from 1893 till 1917 by Paul von Salvisberg (1855-1925) in München. In Hochschul- und Wissenschaftspolirik, Bernhard vom Brocke mentions on page 73; an edition of 13,400 copies. 5000 were delivered to paying subscribers.

82. Althoff had rescued the newspaper financially. The Koppel Foundation provided 200,000 marks and Böttinger an additional 100,000 marks. 


\section{Growth and Institutional Reform of the Academic System}

4.1. Humboldtian Principle

Observation 12: The traditional university system was no longer able to cope with the growing demand for its services.

4.2. University of Straßburg, the Embryonic Althoff System

Obs. 13: Althoff was an experienced manager of science when he assumed a position in the Prussian Ministry of Culture.

4.3. Growth of the Acadenic System

Obs. 14: The academic system, taking the form of a large bureaucracy, expanded rapidly in the. Althoff era.

Obs. 15: Althoff bureaucratized the academic system, which he ran as an integrated system of all academic institutes. 


\subsection{Althoff's Institutional Reforms and Innovations}

4.4.1. Independent Research Institutes

Obs. 16: Research institutes were created that were independent of the traditional universities, in order to allow scholars to devote their efforts solely to research.

\subsubsection{Seminar Research Method}

Obs. 17: The seminar method was a new form of interactive education and research.

\subsubsection{Professional Library System}

Obs. 18: The reform of the German scientific library system was twofold: expansion and structural reorganization.

4.4.4. University Regulations

Obs. 19: Althoff made the university regulations and degree requirements more consistent and less discriminating.

4.4.5. Academic Compensation

Obs. 20: The academic staff earned a basic salary according to a wage scale system for the Prussian bureaucracy, that was supplemented by lecture fees.

Obs. 21: Top scholars earned top wages and researchers of genius obtained their own research institute.

Obs. 22: Marks of honor were an important compensation instrument in the Althoff system.

4.4.6. International Science Policy

Obs. 23: The Ministry of Culture conducted an active international science policy in order to obtain international recognition of German science and scholarship. 


\section{Growth and Institutional Reform of the Academic System}

\subsection{Humboldtian Principle}

Although the universities were financed by the Prussian state, they had remained autonomous organizations that ran their affairs independently. They had their own administration, regulations and some financial resources. In spite of the financial navel-string, the Ministry of Culture only had an administrative function. It did not interfere with scientific and internal matters. Academic freedom was respected and guaranteed by the constitution.

Observation 12: The traditional university system was no longer able to cope with the growing demand for its services.

The universities had worked for decades according to Humboldt's principle of "unity of research and teaching ${ }^{\mathrm{ES}}$ and had held a monopoly position in science and scholarship. In the last third of the nineteenth century, however, scientific progress coincided with the second Industrial Revolution and science itself became increasingly more specialized and differentiated. ${ }^{M}$ Scientific progress could only come from a further division of labor among scholars. The industrial and social demand for new knowledge and the internal development of science brought the universities into a position of increasing research efforts on a scale that they could hardly maintain. Towards the end of the nineteenth century, most fields had become too complex to be handled by a single professor who would teach an entire discipline, including his discoveries. A lot of research became of interest only to other active scholars and required growing investments and cooperation.

The double mission of the prevailing system was also endangered by the increasing teaching load. Demographic reasons and the democratization process in higher education reduced its research resources. The increasing inability to meet the demands of education, professional training and scientific research combined with growing research costs called for expansion as well as structural change. While Althoff maintained the Humboldtian idea of the research mission of a university, he started a gradual reform of the academic system.

83. Einheit von Forschung und Lehre. The second principle is academic freedom.

84. Specialization refers to the more narrow and intensified study of a subject. By differentiation is meant that new disciplines emerged or emancipated. 


\subsection{University of Straßburg: the Embryonic Althoff System}

Many features of the Althoff system were introduced at the University of Straßburg between 1872 and 1882. In his twofold position as an Alsatian public official and Strabburg professor, Althoff learned how to deal with the complexity of administration and academia. The Straßburg experiment is therefore considered the starting point of his reforms in Prussia.

Observation 13: Althoff was an experienced manager of science when he assumed a position in the Prussian Ministry of Culture.

In Straßburg, Althoff was responsible for the procurement of the university buildings. "s He ran a tight schedule, but managed to get the doors open on time. In. Berlin, he drew on this experience for rebuilding the Charite-Hospital and moving the underhoused University of Berlin out of the center of the city. With practical solutions, he had proven himself to be a realistic administrator; by gaining the collaboration of the local authorities and the mayor Otto Back (1834-1917), he proved himself a stimulating manager. Althoff was also in touch with the representatives of the local Protestant Seminary, the Ecole Libre de Médecine, and the municipal hospital to discuss the future relationship of their institutions to the university.

Althoff had gained the respect of his superiors "the Alsatian Governor (Reichlandes Oberprasident), Eduard von Möller (1814-1880), and the experienced Commissioner for the Foundation of the University of Straßburg, Franz Roggenbach (1825-1907). As a Minister of Education in Baden (1861-1865), the latter had been responsible for a reform of the educational system. It was his goal to create an outstanding university. Althoff became the curator of the university when Roggenbach declined. the offer.

Althoff also got involved in the selection of the forty-four full professors and thirteen part-time professors, which was a valuable experience for his future role in Berlin. With the help of Wilhelm Dilthey (1833-1911), a brilliant staff of young scholars was appointed. ${ }^{\text {"6 }}$ Among them the historian Julius Weizsäcker (1829-1889), the classical philologist Wilhelm Studemund (1843-1889), the economists. Gustav Schmoller (18381917) and Wilhelm Lexis (1837-1914), the jurists Karl Binding (1841-1920), Heinrich Brunner (1840-1915), Heinrich Geffcken (1830-1896) and Rudolph Sohm (18411917), an expert in canon law. In medicine, the physicians Adolf Gusserow (18361906), Ernst Leyden (1832-1910) and Wilhelm Waldeyer (1836-1921) were attracted. The famous chemist Adolf Baeyer (1835-1917) also came to Straßburg. Some of them. became loyal advisers to Althoff, especially Gustav Schmoller, Wilhelm Lexis and Wilhelm Studemund. Over the years, Althoff would build an extensive network of academic consultants.

85. Being a jurist, Althoff was also asked to write the foundation, charter and the regulations of the university.

86. The faculty members had an average age of 39 years as compared with 62 years in. Berlin. 
The University of Straßburg grew rapidly. New chairs were created in anthropology, paleontology, ethnography and history of arts. The Law department was split into two separate faculties: Law and Economics. Out of the Faculty of Philosophy grew an autonomous Faculty for Natural Sciences. Straßburg introduced a new interactive learning and research method in so-called seminars that had their own working rooms, libraries and laboratories. These seminars were directed by a senior scholar.

The university possessed Germany's most modern library. After the German bombardment of the municipal library with its valuable collection of manuscripts, Karl Barack, the director of a private library in Swabia, immediately dedicated himself to organizing a replacement. When the library officially opened on August 9. 1871 , it already possessed a total of 120,000 volumes. A decade later, the library had acquired over half a million volumes and was the largest university library in the world, a rank retained until 1920, when the honor passed to the library of Harvard University. ${ }^{\mathrm{n}}$

To attract prominent scholars to Straßburg, the Alsatian professors were paid a salary above the national average. ${ }^{\mathrm{s}}$ Althoff also settled a pension scheme for the widows and orphans of unsalaried lecturers and introduced superannuation on full pay. The idea of filling the same academic chair by a French and German professor, as a way of integrating Alsace-Lorraine into the German Empire, failed upon the revival of nationalist emotions.

Straßburg was a learning school for Althoff. Some of the innovations introduced in Straßburg, were implemented later in whole Prussia. More important, Althoff had acquired the skills to organize the administration of an academic system and had understood the vital function of human resources in science and scholarship.

\subsection{Growth of the Academic System}

The growth of the academic system was impressive. The number of academic institutes, hospitals not included, rose from three hundred twenty in 1882 to four hundred seventy-six in 1907.

Observation 14: The academic system, taking the form of a large bureaucracy, expanded rapidly in the Althoff era.

In 1871, Prussia counted nine universities. ${ }^{9}$ The University of Straßburg opened in 1872, at the event of which Althoff was involved both as a bureaucrat and as a professor. In 1902, the University of Münster was founded. The first academic year of the University of Frankfurt started in 1914, but had been prepared by Althoff. The

87. John E. Craig (1984), Scholarship and Narion Building, p. 60.

88. In 1875, the average yearly salaries were in Göttingen 4000 marks, in Berlin 4800 marks, and in Straßburg 7500 marks.

89. Berlin, Bonn, Breslau, Greifswald, Götingen, Kiel, Königsberg, Marburg and Halle. 
Academy of Posen and the Colonial Institute in Hamburg became universities in 1903 and 1908. A new type of university were the academies for practical medicine in Frankfurt (1904), Köln (1904) and Düsseldorf (1907). At the universities, chairs were created in new fields and new courses were put on the curriculum like e.g. anthropology (Straßburg), pediatrics (Berlin), library sciences (Göttingen) and hygiene.

From 1868 till 1910, eleven technical colleges were founded in Germany, four of which were in Prussia. The colleges in Aachen (1870), Berlin-Charlottenburg (1879), Danzig (1904) and Breslau (1910) were completely new institutes. In 1899, the technical colleges broke the monopoly of the traditional universities to confer doctoral degrees. The Prussian state also set up business schools in Köln (1901), Frankfurt (1902), Berlin (1906) and Königsberg (1915).

Between 1872 and 1911, the number of students that enrolled at German institutes for higher education more than tripled (from 20,000 to 68,000 ), which doubled their share in the entire population. At the universities, German professors had to teach 13.2 students on average in 1872-73. In the academic year 1910-11, the number had increased to 26.3 students per professor. ${ }^{90}$ The total number of academic staff, including the extra-ordinary professors and the (private) lecturers, rose from 1,633 in 1873 to 4,463 in 1910. Over the same period, the number of full professors increased from 853 to $1,263 .^{91}$ The expansion was most spectacular in the natural sciences in Prussia, where the number of students grew from 987 to 7,285 , professors from 154 to 241 , extra-ordinary professors from 76 to 177 and private lecturers from 75 to $262 .{ }^{92}$

Budgetary expenditures for research and education rose accordingly. The Prussian Ministry of Culture was the largest department in terms of its share of the national budget, ${ }^{93}$ and in comparison with other German-speaking countries. In Austria, public expenditures for academic purposes almost quadrupled from 7.6 million crowns in 1875 to 27.7 million crowns in 1914 in nominal terms. The Prussian budget increased from 7 million marks in 1875 to 43.6 million marks in 1913.94 Adjusted for inflation "it rose between two and a half to three times. Average expenditures over a decade rose from 18.8 million marks over the last decade of the nineteenth century to 35.9 million in 1900-1910. Bayern allocated 4.3 to 6.3 million

90. Bernhard vom Brocke (1981a), Preupișche Bildungspolitik, p. 736.

91. Bernhard vom Brocke and Rudolf Vierhaus (1990), Forschung im Spannungsfeld von Politik und Gesellschaft, Deutsche Verlagsgesellschaft, Stuttgart, p. 18.

92. Bernhard vom Brocke (1989a), Anteil Althoffs in der KWG. pp. 129-163.

93. In 1899, the Prussian Ministry of Culture absorbed $28.2 \%$ of total public expenditures. Second and third largest were the Ministry of Finance $(22.2 \%)$ and the Ministry of Justice $(21.7$ \%). Figures in: O. Schwarz and G. Strutz (1900), Der Staatshaushalt und die Finanzen Preupens, Berlin, Band II, Buch I, P. XXV. Quoted in : Bernhard vom Brocke (1980), Hochschul- und Wissenschaftspolitik, F. 22.

94. Bernhard vom. Brocke and Rudolf Vierbaus (1990). Forschung im Spannungsfeld, p. 24. 
marks to its academic system. In Sachsen public expenditures amounted to 3.2 respectively 4.2 million marks, in Baden they rose from 2.7 to 3.7 million marks. ${ }^{\text {ss }}$

It should be noted that the official figures do not reveal the off-budget expenditures and the private financial resources, which the Althoff system tapped so successfully. It has been documented that e.g. private donations quadrupled from 4.8 million marks in 1886-1896 to 18.6 million marks in the following decade. ${ }^{*}$ These figures do not even include the subsidies of local communities. Moreover, the budget figures do not indicate what the universities spent from their own resources.

Observation 15: Althoff bureaucratized the academic system, which he ran as an integrated system of all academic institutes.

"Als Althoff noch mein Kollege in Straßburg war, hat er mir einmal gesagt, sein Ideal sei die Barokratisierung der Universitaten. Ich habe ihn damals ausgelacht; denn das Prinzip, auf dem die Universitäten beruhen, ist dem der Barokratie entgegengesetzt. $"=9$ ?

In the Althoff era, the Prussian academic system expanded and gradually developed into a large organization. It should be noted that Althoff understood the bureaucratization of the academic system in the Weberian sense, i.e. an institutional response for the rational use of resources and the legal use of power. ${ }^{\text {at }}$ As some of the other reforms, bureaucratic management seemed bound to get in conflict with academic freedom. Attempts for a more rational use of resources led the Ministry to concentrate certain activities in the different disciplines in one particular university. ${ }^{\text {n }}$ This university would coordinate scholarly activities in Prussia in a field in which it had strong historical roots or in which the leading scholars belonged to its faculty. ${ }^{100}$ This Schwerpunkabildung was originally an idea of Roggenbach.

95. Frank R. Pfetsch (1974), Zur Entwicklung der Wissenschaftspolitik in Deutschland I750-1914, Duncker \& Humblot, Berlin, p. 52

96. Otto Schwarz (1911), "Stiftungen", in: Handworterbuch der Staatswissenschaften (3rd edition), vol. 7, Jena, p. 1017.

97. Lujo Brentano (1917), Elsasser Erinnerungen, Erich Reiss Verlag. Berlin, p. 115.

98. For a discussion of the controversy between Althoff and Max Weber (1864-1920), see chapter 9.

99. Berlin became prominent in archaeology, history and art. The Universities of Bonn, Kiel and Breslau specialized in respectively Dutch, Skandinavian and Slavic linguistics and literature. Marburg took the lead in archival sciences and complementary historical sciences, German dialectography and, together with Frankfurt, experimental therapy and hygiene. HalleWittenberg became a center for evangelic theology and Gottingen one for mathematics and physics.

100. See: Renata Tobies (1991), "Wissenschaftliche Schwerpunktbildung: der Ausbau Götingens zum Zentrum der Mathematik und Naturwissenschaften", in Bernhard vom Brocke (Hrsg.). Wissenschaftsgeschichte und Wissenschaftspolitik im Industriezettalter, Verlag August Lax, Hildesheim, Pp. 87-108. The University of Göttingen became the center for mathematics and physics because the famous physicists Georg. Lichtenberg (1742-1799) and Wilhelm Weber (1804-1891) and the chemist Friedrich Wohler (1800-1882) had built a tradition in the natural sciences. With Carl Friedrich Gauß (1777-1855), pure and applied mathematics had prospered 
Institutional reforms, like the independent research institutes, the new types of university and the conformity of degree requirements, were implemented precisely to break the protectionist structures of the prevailing system that was no longer able to fulfil the function for which it was designed. ${ }^{101}$ That the measures were taken by a bureaucracy does not necessarily imply that they had a bureaucratizing effect. It is reasonable to say, however, that Berlin took its administrative responsibilities more seriously and pursued a more active science policy, in which universities and research institutes were no longer considered as autonomous entities but as parts of an academic landscape. By taking the integrated system view, Althoff was in a position inject competition in the academic labor market.

The expansion of the academic staff had gradually replaced the old principle of solidarity and equality among scholars by a hierarchy of full professors and institute directors assisted by researchers of lower rank. Althoff observed that the university procedures had not consistently led to the appointment of the most suitable candidates to Prussian chairs. ${ }^{102}$ So, to fill vacant positions, the Ministry started looking for suitable candidates itself years in advance and attracted top scholars to Prussian academic institutes. From the lower to the top levels of the academic hierarchy, Berlin appointed excellent scholars. When they were not the faculty's candidate, this clashed with the old cooptation right, which probably inspired most of the controversy about the bureaucratization of the universities.

\section{Vom Brocke points out that}

"the development of the university system during this period into a large-scale scientific enterprise was not a typical Prussian process. Only in Prussia, it was carried out in a systematic and dynamic manner "controlled centrally and driven on by means of a state bureaucratic system, with the aim of rationalization. For the other German states, it served both as a model and a pace-setter. "103

100. ....

in Göttingen. The tradition was continued by Gustave Dirichlet (1805-1859) and Bernhard Riemann (1826-1866). In the Althoff era, the research of Gaub and Weber on geomagnetism was continued by Martin Brendel (1862-1939), professor of theoretical astronomy and geodesy. and Emil Weichert (1861-1928), professor of geophysics and geomagnetism. They shared the chair of Ernst Schering (1833-1897). Carl Runge (1856-1927), the first Prussian professor of applied mathematics, and Ludwig Prandtl (1875-1953), professor of applied mechanics, were engaged in aviation research for the Motoriuftschiff-Snudiengesellschaft.

101. See observation 12.

102. See observation 26 .

103. Bernhard vom Brocke (1989b), From Science Administrarion to a Policy of Science: An Appraisal of Friedrich Althoff (2/19/1839-10/20/1908), Paper Althoff Conference, Heilbronn, Germany, p. 28. 


\subsection{Althoff's Institutional Reforms and Innovations}

\subsubsection{Independent Research Institutes}

Teaching privileges and research professorships were only partial solutions to the fundamental problem of providing talented scholars with time and means to do research. Top scholars spent a lot of time on lectures, examinations and management duties with little time left for scientific research, while young scientists, who had more time, had less opportunity and financial means. A further increase in the number of academic staff would reduce the teaching load per faculty member and improve the research capacity of the traditional university system. However, a major institutional innovation was introduced, which substantially upgraded Prussia's research performance: the independent research institutes.

Althoff created several independent research institutes, in which scholars could devote their time and effort solely to research. The innovative aspect lay in the fact that these institutes were no longer affiliated with traditional universities. ${ }^{104}$ The institute director did not have to render account to any academic authority, he was solely responsible for the management and performance of his institute. Another innovation was the multi-source financing system. Institutes were financed mostly in a jointventure of the state, industry, banks, private funds, municipalities and chambers of commerce. ${ }^{105}$

Some institutes had been founded before Althoff. Prussia had been the first German state to establish independent institutes. However, the goal of the earlier institutes was not so much to do research as to serve some practical ends. ${ }^{106}$ They were involved e.g. in the verification and stamping of weights and measures or the control of patents. The Physikalisch-Technische Reichsanstalt (PTR) was the first major public research laboratory that was not connected with an academy, a university or a technical college. It was founded by the astronomist Wilhelm Foerster (1832-1921), the physicist Hermann Helmholtz (1821-1894) and the industrialist Werner Siemens

104. After the Prussian example, the creation of independent research institutes became an international process. Well-known are the Pasteur Institute in Paris (founded in 1888), the Rockefeller Institute for Medical Research in New York, (1901), the Carnegie Institute for Fundamental and Scientific Research. in. Washington (1902) and the Carlsberg Society in Copenhagen. Still affiliated to an academy were the Institute for Radium Research of the Viennese Academy (1908) and the Nobel Institute for Physical Chemistry in Stockholm (1905). Althoff was well informed about these international developments, which gave further impulses to his own plans.

105. See observation 32 .

106. In 1847, the Royal Meteorological Institute was set up in Berlin after a proposal of Alexander von Humboldt (1769-1859). The initiative. was followed by the Geodesic Institute (1869), the Astronomic Institute (1874) and the Astrophysical Observatory in Potsdam (1874). The latter was created by Wilhelm Foerster for weather report purposes. The German Ministry of the Interior set up several institutes, for purely practical purposes like the Gauging-Committee (1868), the Imperial Health Office (1876), the Imperial Patent Office and the Biological Institute (1905). The Archaeological Institute with branches, in Rome and Athens was taken over by the federal Ministry of Foreign Affairs from the Prussian state. 
(1816-1892) in 1887. ${ }^{107}$ The mission of the PTR was to pursue basic and applied research for the benefit of German industry. At the institute, Max. Planck (1858-1947) did his famous research on quantum theory. The empirical results obtained at the PTR led to his well-known radiation-formula, which he also tested at the PTR. The 1911 Nobel Prize Winner for Physics, Wilhelm Wien (1864-1928) also worked here. As a result, it gained an international reputation as a center for empirical and fundamental research in physics. ${ }^{108}$

Observation 16: Research institutes were created that were independent of the traditional universities, in order to allow scholars to devote their efforts solely to research.

In the nineties, Althoff was involved in the creation of some famous institutes for medical and biological research. In 1891, the Royal Institute for Infectious Diseases was founded in association with the Charite. ${ }^{100}$ Its first director was Robert Koch (1843-1910), who taught at the University of Berlin from 1885. Koch had made his path-breaking bacteriological discoveries at the Imperial Health Office, not at the university, in the early eighties. Famous scholars would come to work at the institute, among them Paul Ehrlich (1854-1915). The institute was also a model for the Imperial Japanese Institute, ${ }^{110}$ which was directed by Koch's student, Shibasaburo Kitasato (1853-1931). ${ }^{11}$

In 1891, the Biological Observatory was opened in Plön. It was financed by wealthy citizens and the city of Plön, a local scientific fraternity and the Prussian state. ${ }^{112}$ The observatory was complemented by the Biological Institute and the North Sea Museum on Helgoland. They were both set up in 1892 with the financial help of citizens of Breslau. The Helgoland institute studied problems related to fishery and fish biology. Friedrich Heincke (1852-1929) was its first director. The Ministry of Culture also took over the Zoological Institute in Napels, which had been founded by Anton Dohrn (1840-1909) in 1872.

In 1896, Paul Ehrlich opened the Institute for Serum Research and Therapy in BerlinSteglitz. ${ }^{113}$ Three years later, it was transferred to Frankfurt a.M. with a new name: Institute for Experimental Therapy. Its task was to study immunity and develop serums. Ehrlich had worked at the Koch Institute on diphteria, but felt constrained by his tutor. Althoff got him his own institute, a joint-venture of a large private fund for

107. Siemens donated the building site, worth half a million marks. He granted an additional 300,000 marks for the construction of the buildings.

108. Similar institutes, modeled after the PTR, were created in Russia in 1893, England 1900, USA 1901, France 1902, Japan 1917.

109. Konigliches Institut fur Infektionskrankheiten.

110. The Imperial Japanese Institute was founded in 1892.

111. Kitasato discovered the pestbacillus with Koch in 1890 . He developed the tetanus serum with Emil Behring (1854-1917).

112. The institute became very famous, for the research carried out by August Thienemann (18821960). Otto Zacharias (1846-1916) took the initiative for an observatory.

113. Institut far Serwmforschung und Serumtherapie. 
chemotherapeutical research, ${ }^{1 / 4}$ the city of Frankfurt, the firm Cassella and the Hoechst corporation, which was represented by August Laubenheimer (1848-1904). Emil Behring (1854-1917) had also worked at Koch's institute. He continued the research on diphteria, but also investigated tuberculosis. Behring became the first director of the Institute for Experimental Therapy and Hygiene in Marburg (1899). The institute was financed by the Hoechst corporation, which, in return, was allowed. to put the serums into production, while the state set the prices. Ehrlich and Behring carried out Nobel Prize winning research at their institutes.

The Gōttingen Association for the Advancement of Applied Physics and Mathematics, ${ }^{115}$ founded in February 1898, was an initiative of Henry Böttinger and Felix Klein (1849-1925). ${ }^{116}$ In ten years time, the association created five institutes, ${ }^{117}$ and financed five new chairs, among, which Ludwig Prandtl's professorship in aeronautics. ${ }^{11}$ It was a self-administered, privately funded organization. The board consisted of scholars, but also contained representatives of the state and the industry. ${ }^{119}$ The Ministry of Culture looked after the academic freedom of the scholars from commercial pressure and industrial interests.

The independent research institutes challenged the Humboldtian principle. Teaching. and research were no longer necessarily parts of the same task. However, the top scholars who directed these institutes often combined it with a professorship, so that in practice the Humboldtian idea was still largely intact. Nevertheless, the institutes, in which scholars with a proven research record carried out their own program, were. administratively and financially independent from the rest of the academic system.

The independent research institutes and the Dahlem project paved the way for the famous Kaiser-Wilhelm-Gesellschaft that was founded in 1917. Dahlem was already in a far stage of development when Althoff died. ${ }^{120}$ It would become a park in which researchers of genius would be offered non-lecturing research institutes for fundamental research, ${ }^{121}$ It was not meant to replace, but to complete the efforts of

114. Georg-Speyer-Haus.

115. Gortinger Vereinigung zur Forderung der angewandten Physik und Mathematik.

116. Klein is well-known for his contributions in the field of uniformization theory.

117. Institutes in applied mathematics, applied mechanics, applied electricity, geophysics and inorganic chemistry.

118. Prandtl (1857-1953) led the Motorluftschiff-Studiengesellschaft of the Gortinger Vereinigung, where he did research on hydro- and aerodynamics and aviation.

119. Althoff, who had pushed the creation of the Association, was an honorary member.

120. Althoff had brought up the matter to the Emperor, who reserved 100 hectares in Dahlem for state research institutes. In 1905, the first independent research institute in. Dahlem was foun:ded: the Imperial Biological Institute for Pedology and Forestry. Soon, the famous chemists Emil Fischer (1852-1919), Walther Nernst (1864-1941) and Wilhelm Ostwald (1853-1932) began asking for a Chemical Research Institute.

121. Especially, but not exclusively, in natural sciences (physics, radioactivity, electron research, serum. research, inorganic chemistry, biochemistry, biology, brain research, comparative anatomy and comparative physiology). Althoff's plan for a central Institute for Research on German History was realized in 1917. The Kaiser-Wilhelm-Institut fur deutsche Geschichte 
the universities. The professors at the Kaiser-Wilhelm institutes had no administrative tasks nor any teaching or examination duties. Althoff also had plans to move the University of Berlin and the Royal Library to Dahlem. ${ }^{12}$

\subsubsection{Seminar Research Method}

Observation 17: The seminar method was a new form of interactive education and research.

From Straßburg came a new form of postgraduate education and research: the seminars. Althoff created several of them at every Prussian university. A seminar had its own working rooms, library or laboratory and was led by a senior scholar, who carried out his seminar research program. The students participated in this program. It served a triple goal: (1) the participants acquired problem-solving skills by carrying out their own research projects while learning from the results of other research,(2) the diversity of the students allowed a multi-disciplinary research approach, (3) promising academic scholars were taught the methods of research by working with an experienced researcher. This interactive method of learning was quite unorthodox as compared with the traditional ex cathedra lecturing.

In the Althoff era, nine seminars for economics and political science were created at Prussian universities. Gustav von Schmoller, the leading economist of the Young Historical School, accepted the call to the University of Berlin only on the condition of having his own seminar, which did not, yet exist in Berlin. Most seminars were established in the fields of geography, Romanic and English philology, philosophy and psychology, which was a fairly new discipline.

\subsubsection{Professional Library System}

Althoff was impressed by the university library of Straßburg. The rest of the Prussian and German libraries, however, which were run voluntarily by professors after working hours, were in a poor state. To upgrade the system, Althoff consulted the General Director of the Royal Library August Wilmanns (1833-1917) and other experts like Otto Hartwig (1830-1903), Karl Dziatzko (1842-1903) and Wilhelm Erman (1850-1932), who were the Directors of the libraries of Halle, Göttingen and Berlin:

Observation 18: The reform of the German scientific library system was twofold: expansion and structural reorganization.

121. ... replaced earlier efforts of the Prussian. Historical Institute in Rome (1888) and the Historical Institute for Art in Firenze (1897).

122. Bernhard vom Brocke and Rudolf Vierhaus (1990), Forschung im Spannungsfeld, p. 121. 
Better housing was an urgent problem. The Royal Prussian Library and all the university libraries, except for Breslau, got new buildings. A simple measure was to supply more books and scientific journals on the library shelves. Althoff knew, of course, that mere expansion would not lead to a better use of the libraries. Therefore, the growth in the volume of books and journals was accompanied by a new uniform cataloguing system in Prussia. ${ }^{13}$ Schilfert argues that

\%.. I die entscheidende Tat der Althoffschen Bibliotheksreform die Lôsung der zehn preußischen Universitätsbibliotheken aus ihrer Isolierung und das Zusammenfügen zu einem festen. Verbund war, "

The dual system of university libraries and specialized seminar and institute libraries became better integrated by an innovative system of interlibrary-loans (1893).

More innovative was Althoff's professionalization of libraries. To give future librarians a formal. and relevant training, a professor was appointed to the first chair in library sciences in Göttingen in 1886. Next, genuine career opportunities were opened for librarians. The reforms of 1893 gave them the same career prospects as university professors. ${ }^{125}$

\subsubsection{University Regulations}

University regulations and degree requirements were often fragmented, inconsistent and discriminating. The fact that examination requirements were unregulated would not have caused state action if the different faculties would have held more or less equal standards for equal degrees. However, the Ministry was forced to take action by the justified foreign criticism of German doctoral procedures.

Observation 19: Althoff made the university regulations and degree requirements more consistent and less discriminating.

In 1897, the Ministry of Culture determined the requirements for a Prussian Law degree in cooperation with the Ministry of Justice. The process was repeated in 1901 for medicine. With the approval of the Office of the Chancellor, standards were spelled which a practising physician had to meet.

Crucial in the process of rationalizing the degree requirements was the foreign criticism on German doctoral procedures. On some German universities, candidates could earn their doctor's degrees in absentia and without producing any research

123. The Preupische Instrultionen of $1899 / 1908$.

124. Sabine Schilfert (1989), "Friedrich Althoff und die wissenschaftlich-technischen Hochschulbibliotheken - Eine Studie zum Arbeitsstil Althoffs", in: I.T.W., Friedrich Althoff. 1839-1908, Akademie der Wissenschaften der DDR, p. 103.

125. For example, the mathematician Dr. Heinrich Simon (1858-1930), who had devoted himself to a library for technical sciences, became the director of all Prussian technica! libraries, having the rank and title of professor. 
document. This led to serious abuses, in which degrees were simply sold for money. In order to maintain international respect for German scholarship and protect the brand name of the German doctor's title, reforms could no longer be postponed. In 1887, Althoff regulated e.g. the doctoral requirements at the Göttingen Law Department. They now included oral exams and a printed dissertation. As a result, many students went to universities outside Prussia.

In spite of many efforts, Althoff was unable to push forward a consistent policy on the federal level. Without doubt, the "cultural objections" of the non-Prussian universities were intertwined with financial reasons since the registration fees for doctor's degrees were very high. Later reform attempts, which were initiated by the academic authorities themselves instead of by the state "all failed, which leads vom Brocke to conclude:

"Es wurde nur wieder einmal das bis heute nicht widerlegte Faktum bestärigt, daß Hochschulreformen allein aus der akademischen Selbstverwaltung heraus offenbar unmoglich sind. " 120

In Germany, there was another debate going on about the right of the technical colleges to confer doctoral degrees in engineering. ${ }^{127}$ A positive conclusion would imply the scientific equality of technical colleges and universities and break the latter's monopoly. Kahlow has argued that the debate was won by the technical colleges on scientific grounds. ${ }^{128}$ The state classification of materials, which was based on solidity studies of a high theoretical level, also helped their cause significantly. It should be mentioned that chemistry was taught at universities and technical colleges and it was clear that the latter were not behind in development. So, the technical colleges obtained the right to confer the doctor's degree in 1899 .

Althoff was also responsible for a school reform. The Prussian system of secondary education consisted of three types: the Oberrealschule, the Realgymnasium and the Gymnasium. ${ }^{129}$ Only graduates from the Gymnasiums were allowed to go to a university, although the different schools offered the same type of education at a comparable level, emphasizing, however, different disciplines. Due to the monopoly of the Gymnasium, the students of the other two school types were only allowed to

126. Bernhard vom Brocke (1980), Hochschul'- und Wissenschaftspolitik, p. 63.

127. Dr.-Ing. or doctor rerum technicarum (a doctor's degree in engineering).

128. Andreas Kahlow (1989), "Der Technikerstreit im letzten Drittel des 19. Jahrhunderts", in: 1.T.W., Friedrich Althoff 1839-1908, Akademie der Wissenschaften der DDR, Berlin, p. 120. In particular, Carl Culmann's graphic statistics (1866-1875), Gustav Zeuner's mechanical thermodynamics (1860), Franz Grashof's study of mechanical machines (1875) and Franz Reuleaux's theoretical cinematics (1875) gave evidence to the claim that mechanical technology was, in fact, an applied science.

129. Traditional education at the Gymnasium concentrated on the study of the classical languages Latin and Greek. Modern languages like French and English were also taught. The study of English was carried through in 1901 at the request of the Emperor. In 1859, the Realgymnasium was created, which also included classes in Latin, but emphasized the study of modern languages and natural sciences. The Oberrealschule, founded in 1882, provided a comparable general education, but Latin was no longer on the student's curriculum. 
study at technical colleges or at commercial and artistic institutes. At the school conference of June $4-6,1900$, Althoff changed the system. All German high school graduates now had equal opportunities for formal admittance to a university. ${ }^{190}$

\subsubsection{Academic Compensation}

Observation 20: The academic staff earned, a basic salary according to a wage scale system for the Prussian bureaucracy, that was supplemented by lecture fees.

Prussian academic scholars were civil servants, hired by the Ministry of Culture. As in the rest of the public administration, they were paid a salary, which was determined by an official wage scale. The system set the initial basic salary and attributed pay increases according to seniority and years in office.

Lecture fees counted for a substantial part of total income of university staff. For example, Max Planck earned a salary of 6,000 marks in 1906 as a professor in Berlin. The average salary of a professor was 4,000 marks. Planck made an additional 4,000 to 5,000 marks in lecture fees. ${ }^{131}$ Althoff introduced a marginal tax of fifty percent on lecture fee earnings rising above 3,000 marks. ${ }^{132}$ The proceeds were deposited in a reserve fund that was set up, in the first place, to attract top scholars to Prussian universities and, in the second place, to aid the unsalaried lecturers. Althoff made other serious efforts to improve the financial position of the lecturers. In 1889, he extended the idea of the Straßburg pension fund for the widows and orphans of unsalaried lecturers to all of Prussia. When Althoff retired, he set up the Wilhelm Relief Fund to help scholars and their families with financial problems. ${ }^{133}$ Henry Böttinger donated 100,000 marks. ${ }^{134}$

Observation 21: Top scholars earned top wages and researchers of genius obtained their own research institute.

Although the Althoff system introduced the bureaucratic wage scale system, considerable flexibility was built into the compensation system in order to attract top scholars. The Ministry of Culture could pay very high wages; to top scholars, with an international reputation. ${ }^{135}$ In Austria, on the contrary, each agreement on salaries which did not conform with the norm of the salary system, was dependent on the approval of the Ministry of Finance. The Austrian Ministry of Culture did not have

130. Bernhard vom Brocke (1981a), Preubische Bildungspolitik, p. 735.

131. Walther Hoflechner (1989), Austrian University System, p. 10, ftn. 46.

132. In Berlin, the first 4,500 marks was exempted from, the tax. Althoff was only partiy successful in restricting the excessive private clinical practices of some physicians.

133. Wilhelm-Stiftung fur Gelehrte.

134. Bernhard vom Brocke and Rudolf Vierhaus (1990), Forschung im Spannungsfeld, p. 103.

135. With the 1900 average salary of a full professor somewhere around 4,000 marks, a true top scholar like Wilamowitz-Moellendorf earned a yearly salary of 15,000 . 
any financial discretion, which would have allowed it to improve a compensation offer and move rapidly on the academic market.

Part of the attraction for top scholars to work at Prussian academic institutes were the outstanding research facilities they were offered. ${ }^{136}$ Getting their own research institute was part of the compensation package. As the director of an institute, they could carry out a research program of their own interest. They managed their own research institute, allocating resources to scientific instruments and assisting personnel.

Observation 22: Marks of honor were an important compensation instrument in the Althoff system.

The value of marks of honor should not be underestimated in the Imperial era. It represented a form of social recognition, opening doors for its holders that remained closed otherwise. Althoff did not have the authority to grant marks of honor. So, he had to induce others to reward scholars with distinction marks. ${ }^{137}$ Althoff successfully applied the same technique to private money-providers of public research projects. ${ }^{138}$

\subsubsection{International Science Policy}

Observation 23: The Ministry of Culture conducted an active international science policy in order to obtain international recognition of German science and scholarship.

The educational stands of the Prussian Ministry of Culture at the World Exhibitions of Chicago (1893), Paris (1900) and St. Louis (1904) were so successful that they are considered the start of Germany's international science policy. At the exhibitions, information was exchanged about ongoing research and teaching practices in Prussia and abroad. ${ }^{139}$

136. See observation 16 :

137. For example, Felix Klein was honored with the Roter Adlerorden 4. Klasse in 1889 and the Roter Adlerorden 3. Klasse mit Schleife in 1892. He also became a secret adviser to the government (Geheimer Regierungsrath). Wilhelm Foerster received the Kronenorde 2. KJasse in 1886 .

138. See observation 33 .

139. In 1893, Althoff asked Felix Klein, visting Chicago, to survey the participation of American women in higher education. Two years later, the Chicago professor Heinrich Maschke (18531908) sent the first American female student to study mathematics with Klein in Gortingen. After that, the University of Göttingen started receiving female students on a regular basis from the United States, the United Kingdom and Russia. They pushed the situation of Prussian women, who were admitted to Prussian universities in 1908. 
The relation with foreign countries took its most prominent form in the international exchange professorships between Germany and the United States. ${ }^{100}$ They were a major innovation. There are no records showing any systematic exchanges before Althoff's time, although there are many examples of invited lecturers and visiting professors. ${ }^{141}$ Peter Senn argues that, if the German universities wanted the full benefits of intellectual relations with American institutes, another system than the prevailing haphazard professorial traffic had to be set up.

Although the original idea probably stems from members of the Germanistic Society in the United States, Althoff was largely involved in bringing the venture to a formal conclusion. He institutionalized the exchange with Harvard, in spite of the opposition from the Berlin professors, who viewed it as an implicit recognition of academic equality with their American colleagues. Althoff succeeded by gaining the support of the Emperor and Adolf Harnack (1851-1930) and arranged the financing of the professorships by the Koppel Foundation. ${ }^{102}$ After efforts of Althoff and Nicholas Murray Butler, a second exchange program followed with Columbia University. These exchange professorships were under the auspices of the Emperor of Germany and the President of the United States, indicating the importance of the international science policy.

In 1904, the Academic Information Bureau was founded at the University of Berlin, ${ }^{163}$ while its counterpart opened at Columbia University in New York. ${ }^{144}$ A network of cultural institutes was established at Harvard (1900), Columbia (1911) and the University of Pennsylvania in Philadelphia (1912). They were called the German Houses. International cooperation also led to the foundation of the German School of Medicine in Shanghai (1907) and the German-Chinese University in Tsingtao (1909).

Althoff believed that international science policy could make constructive contributions to world peace and understanding between nations. To promote scientific and human cooperation, Althoff founded the International Journal for Science, Culture and Technology, ${ }^{145}$ in which prominent scientists from the United States, England, France and Italy published.

140. For an extensive report, see: Peter Senn (1989), Where is Althoff ? Friedrich Althoff in English: How has he fared?, Paper Althoff Conference, Heilbronn, 66 pp.

141. A true professorial exchange is when two professors from two universities take each other'? place for a specified period of time.

142. The Koppel-Stiftung zur Forderung der geistigen Beziehungen Deutschlands zum Auslande was endowed, with a capital of I million marks by the banker Leopold Koppel. (1854-1933).

143. The Academic Information Bureau (Akademische Auskunftstelle) informed foreign students about studying in Germany and German students about academic programs abroad. Althoff used it to get an idea about the international position of Germany in research and education.

144. In 1903, a German Museum was created at Harvard. Its counterpart, the America Institute in Berlin, was founded in 1910 and directed by Hugo Münsterberg (1863-1916).

145. Internationale Wochenschrift fur Wissenschaft. Kultur und Technik. The journal replaced the weekly addendum of the German newspaper, the Allgemeine Zeitung, in which Althoff previously had spread his ideas on international science policy. 


\section{Methods and Means of the Althoff System}

\subsection{Academic Information}

5.1.1. Academic Statistics

Observation 24: The Althoff system marks the start of statistical studies, that would underlie the modern administration of science in Germany.

5.1.2. Network of Confidential Agents

Obs. 25: An extensive, informal network of confidential agents provided Althoff with qualitative academic information as well as additional financial resources.

\subsection{Academic Appointments}

\subsubsection{Selection Procedure}

Obs. 26: When Althoff appointed a member of the academic staff, he combined expert knowledge on the scientific situation of a discipline with accurate scholarly appraisals of the academic performance of the candidate.

Obs. 27: Althoff respected the traditional academic rights as long as they were not used for the protection of vested interests.

Obs. 28: The autocratic "personal regime" of Althoff was not absolute.

\subsubsection{Researchers of Genius}

Obs. 29: Althoff not only appointed suitable candidates to existing, chairs, he also created new positions with excellent research facilities in order to attract top scholars.

\subsubsection{Minorities}

Obs. 30: Althoff gave scholars who belonged to a minority group equal opportunities to an academic career. 


\subsection{Academic Freedom}

Obs. 31: The Ministry of Culture protected academic freedom as guaranteed by the constitution.

\subsection{Financia! Resources}

Obs. 32: Althoff built a multi-source financing system for the academic system.

\subsubsection{Prussian Ministry of Finance}

5.4.2. Local Authorities, Chambers of Commerce and Academies

5.4.3. Industry and Banking

5.4.4. Private Foundations

5.4.5. Incentives to Finance Academic Research

Obs. 33: Orders, ennoblement and licences were specific incentives to attract private money for academic research. 


\section{Methods and Means of the Althoff System}

Around the turn of the century, the Prussian Ministry of Culture was the driving force behind several important academic innovations. such as the seminar structure, the independent research institutes and a modern library system. To pursue this innovative science policy, the Althoff system used some very specific methods. It operated a complete network to obtain information about academic activities and it also looked for discretionary financial means, other than the traditional state subsidies.

\subsection{Academic Information}

\subsubsection{Academic Statistics}

Observation 24: The Althoff system marks the start of statistical studies, that would underlie the modern administration of science in Germany.

Every administration needs reliable data on the factors that affect the effectiveness of its department. The official information about academic teaching and research was published in annual university chronicles and reports of research institutes and hospitals. Althoff studied them with great care, as he did the statistical records of the Ministry of Culture, which revealed among other things the number of students attending lectures. To obtain additional and more accurate data, he ordered several statistical studies. ${ }^{146}$ It marked the start of a modern, rational administration of science.

\subsubsection{Network of Confidential Agents}

Observation 25: An extensive, informal network of confidential agents provided Althoff with qualitative academic information as well as additional financial resources.

The most characteristic feature of the Althoff system was the large, informal network of confidential agents that extended in the entire German society. ${ }^{147}$ Althoffs

146. Studies about the statistical evolution of student numbers and public expenditures were carried out by the economists Johannes Conrad (1839-1915) and. Wilhelm Lexis (1837-1914) in 1884. 1889 and 1891. Statistik der preupischen Landesuniversitaten was written by the same authors. Bibliographie der deutschen Universitaten (1904 and.1905) by the librarians Wilhelm Erman (1850-1932) and Ewald Horn (1845-1923) offered a useful survey of the German academic system.

147. It led Althoff into the Ministry of Finance, where he was in close contact with the refendary in charge of the budget for the Ministry of Culture. 
confidential consultants were often highly qualified individuals, who worked in the government, the state bureaucracy, parliament, political parties, industry and the press. Part of this informal network was revealed after Althoff's death, when 136 high-ranked German officials signed a list for the creation of a Friedrich Althoff Fund. ${ }^{14 \pi}$

The main network was inside the academic community. It was designed to obtain qualitative information about academic issues in order to supplement the quantitative and official data. Since the official channels did not always provide Althoff with sufficient unbiased information, he had confidential consultations with leading scholars in every discipline and from every German university. The academic agents were asked to give their reasoned opinion on a number of issues. They informed Althoff e.g. about the state-of-the-art in their discipline as well as where promising scientific progress was made. They were asked to express their professional opinion about specific institutional reforms or to evaluate the academic performance of a potential chairholder.

"Eine zentrale Bedeutung bei der Initiierung und Realisierung der von Althoff betriebenen Wissenschaftspolitik kam dem System informationeller Beziehungen zu, daß Althoff in nahezu perfekter Weise organisierte. Seine Informationspolitik bildete die Grundlage fur einen sachlich fundierten wissenschaftspolitischen Entscheidungsprozeß und war gleichzeitig Voraussetzung für eine von hoher Sachkenntnis getragenen Berufungs- und Personalpolitik. Die Qualität zeigte sich darin, daß er aberall die besten Fachkenner als Berater hinzuzog, immer ein offenes Ohr für sachliche Winsche hatte, durchaus auch von sich aus aktiv wurde und Wissenschaftler danach befragte was für ihr Fach besonders nötig sei. Althoff hatte ein ganzes System von Vertrauensleuten an jeder Universität, in jedem Fach, ein Kreis der fuhrenden Fachgelehrten seiner Zeit. "149

Consider e.g. the role of Wilhelm Foerster. ${ }^{150}$ At the request of Althoff, he wrote a confidential report in 1885 on the problems of the cosmic sciences in general, and of the Geodesic Institute in particular. ${ }^{151}$ After hearing other scholars, among whom Robert Helmert (1843-1917), ${ }^{152}$ Althoff agreed that a new charter would be drawn up for the Geodesic Institute that would focus its activities on research. It became a

148. Among the signatories were the Chancellor of the Empire, five ministers, seventeen members of parliament, three mayors, one cardinal, twenty-five leading bureaucrats, six university curators, forty-nine professors, nine bankers and captains-of-industry, several publishers, heads of schools, libraries and archives.

149. Ralph-Jürgen Lischke (1989), Friedrich Althoff, p. 20.

150. Wilhelm Foerster (1832-1921) introduced the metric system in Germany (in 1869), was involved in the Paris Meter Treaty (May 20, 1875), founded four stations on the German north and east coast (between 1874 and 1877) as well as the Astronomic Society (1863), the Astronomic Computing Institute (1874) and the Astrophysical Observatory in Potsdam (1874).

151. Klaus-Harro Tiemann (1989), "Das Zusammenwirken von W.J. Foerster und F.T. Althoff auf dem Gebiet der Geo- und Kosmoswissenschaften", in: 1.T.W., Friedrich Althoff 1839-1908, Akademie der Wissenschaften der DDR, Berlin, pp. 57-70.

152. The first professor of geodesy at the University of Berlin. 
leading institute in the field. According to the initial plan of Althoff, the Seminar for Foreign Languages in Berlin had to be complemented by a Geographical-Technical Seminar, in which, among other subjects, climatology would be studied. The feasibility of this project was assessed in Foerster's valuable confidential report of 1894, ${ }^{153}$ It should also be mentioned that Foerster was a friend of Adolf von Scholz (1833-1924), the Prussian Minister of Finance (1882-1890). Foerster acted as a liaison between Althoff and the Finance Minister.

The following list, which is not exhaustive, illustrates the extent of the academic network. ${ }^{14}$ In Berlin, Althoff frequently consulted professor Theodor Mommsen (1807-1903), the world-famous classicist, as well as the respected historian of ancient philosophy Eduard Zeller (1814-1908), Rudolf Virchow (1821-1902), Bernhard Weiß (1827-1918) and Friedrich Paulsen (1846-1908) also gave advice to Althoff. In the economic sciences. Althoff sought the opinion of the economists Gustav Schmoller. leader of the Young Historical School, and his scholarly opponent Adolph Wagner (1835-1917), as well as the economist Wilhelm Lexis from the University of Göttingen. Other loyal consultants were the influential theologian Adolf Harnack, the physician Robert, Koch, the chemist Emil Fischer (1852-1919) and the astro-scientist WilheIm Foerster.

In Göttingen, Althoff was in close contact with Felix Klein and the hellenist Ulrich von Wilamowitz-Moellendorf (1848-1931). At the University of Marburg, he consulted the physicians Eduard Külz (1845-1895) and Emil Behring as well as the jurist Ludwig Enneccerus (1843-1928). From. Halle came confidential information from the psychologist Eduard Hitzig (1838-1907). Althoff kept a special relation to the University of Straßburg, where he asked the classical philologist, Wilhelm Studemund (1843-1889) for his opinions. The chemist Wilhelm Ostwald (1853-1932), the economist Lujo Brentano (1844-1931) and the philosopher Wihelm Dilthey (18331911) were also network members that worked at the Alsatian university. Other. confidential agents were the economist Johannes Conrad, the psychologist Hugo Münsterberg and the historian Karl Lamprecht (1856-1915),

Consider the extent of the academic network e.g. in a discipline like chemistry. Althoff was in contact with the leading scholars of the time: Adolf Baeyer (18351917), Emil Fischer, August Hofmann (1818-1892), August Kekulé von Stradonitz (1829-1896), Wilhelm Ostwald and Otto. Wallach (1847-1931). Zirnstein showed in great detail how the informal academic network functioned in the field of biology ${ }_{*}^{155}$ Althoff had many important advisers among the leading biologists in

153. Denkschrift aber die technisch-wissenschaftliche Ausbildung fur den Kolonialdienst usw., zu deren Einreichung Sie mich auf Grund meiner Mitteilungen aber die auf diesem Geblete obwaltenden Obelstande aufgefordert haben.

154. See also: Bernhard vom Brocke (1980), Hochschul- und Wissenschaftspolitik, pp. 70-82.

155. Gottfried' Zirnstein (1991), "Friedrich Althoffs Wirken für die Biologie in der Zeit des Umbruchs der biologischen Disziplinen in Deutschland, der Erneuerung ihrer Forschung und Lehre an den Universităten und des Rufes nach außeruniversitären Forschungsstätten, 1882 bis $1908^{\circ}$, in: Bernhard vom Brocke (Hrsg.), Wissenschaftsgeschichte und Wissenschaftspolitik im Industriezeitalter, Verlag August Lax, Hildesheim, pp. 355-375. 
Germany. Different opinions and heterogenous scientific approaches prevailed. ${ }^{156}$ Zirnstein found that when the chair of physiology at the University of Berlin became vacant after the death of professor Emil Du Bois-Reymond (1818-1896), Althoff got in contact with almost every significant physiologist living in Germany.

The Althoff network included many foreigners as well. The most active correspondent was the Viennese jurist, professor Emil Schrutka-Edler von Rechtenstamm (18521918). Wendel found documents of academic agents in St. Petersburg, Libau, Dorpat, Lemberg, Czernowitz, Innsbruck, Krakau, Graz, Wien, Praha, Budapest and universities throughout the United States. ${ }^{157}$

The confidential network sometimes caused tensions with the official interlocutors who felt they were being bypassed. In February 1894, Ernst von Meier (1832-1911), the curator of the University of Göttingen, resigned because he was tired of the "informal curators" Klein and Lexis. ${ }^{19}$ " A few months later, he was succeeded by Ernst Höpfner (1836-1915), ${ }^{199}$

Nevertheless, effective measures and good decisions depended on high quality, often confidential information on many academic and scientific issues. As Boschan points out:

"Ihm [Althoff] vorzuwerfen, daß er sich auf das Sorgfaltigste nach allen Leuten erkundigt, die er mal eventuell anstellen könnte, ist einfach kindisch, solche 'Spionage' gehört zu seinem Metier. "160

Althoff was mainly concerned with the appointment and employment of an excellent academic staff, as well with money-raising to create an environment that would induce scholars to perform well. The carefully crafted network was useful with regard to both aspects.

156. Zirnstein studied the correspondence between Althoff and the mycologist Oskar Brefeld (18391925), the physiologist and marine biologist Victor Hensen (1835-1934), the zoologists Oscar Hertwig (1849-1922) and Richard Hertwig (1850-1937), the zoologist Karl Móbius (18251908), the evolutionary physiologist Wilhelm Roux (1853-1933), the botanists Adolf Engler (1844-1930), Johannes Reinke (1846-1931) and Simon Schwendener (1829-1919) and many researchers in medicine as well, among whom, of course, Emil Behring and Paul Ehrlich.

157. Günther Wendel (1991), "Aktivităten Althoffs. zum Wegennetz europăischen Geistes. Die Einbeziehung ost- und sudeuropāischer Universităten in das System Althoff", in Bernhard vom Brocke (Hrsg.). Wissenschaftsgeschichte und Wissenschaftspolitik im Industriezeitalter, Verlag August Lax, Hildesheim, pp. 123-154.

158. Renata Tobies (1989), 'Zum Verhältnis von. Felix Klein und Friedrich Althoff', in: I.T,W., Friedrich Althoff, Akademie der Wissenschaften in Berlin, p. 37.

159. Hopfner came from the Ministry of Culture, where he had worked as a referendary. He fully supported the plans of transforming Göttingen into a center for applied mathematics and phy. sics and fostered the cooperation of science and industry.

160. Bärbel Boschan (1989), "Die Entwicklung der Philosophischen Fakultăt der Berliner Unversitāt im Zeitraum 1870-1900", in: I.T.W.. Friedrich Althoff 1839-1908, Akademie der Wissenschaften der DDR, Berlin, p. 72. 


\subsection{Academic Appointments}

The control of academic appointments was another key feature of Althoff's science policy, aimed at occupying Prussian chairs with the finest of scholars. As mentioned earlier, it inspired much of the controversy on the bureaucratization of the academic system.

"Der Ipersönlichkeitsbezogenen Stil der Wissenschaftsforderung/ kontrastien mit der bürokratischen Traditionslinie des preußischen Obrigkeitsstaates, und sie machte sich oft genug in Kollision mit der letztgenannten geltend. Sie dankt einen Teil ihrer Wirkung dem Kontrast zum regularen Hintergrund einer stark hierarchischen, barokratischen und reglementierten Ordnung, deren Ausnahme sie bildet. $^{-101}$

While the results of Althoff's methods. were mostly beyond dispute, criticism came at the centralized control and the confidential methods of the Althoff system. Althoff held true scholarship and erudition in high esteem, but had often been exposed to the opposite. He had developed a sharp and patronizing attitude towards a large part of the academics, which may explain some of the criticism as well. Nevertheless, Althoff. was given due credit for having selected, attracted and promoted the career of prominent scholars, who often were personally indebted to Althoff for their scientific development.

\subsubsection{Selection Procedures}

The faculty that had a vacant or new chair, first looked for candidates itself and then sent a list to the Ministry of Culture. In most cases, the administration in Berlin respected the cooptation right and appointed the candidate whom the faculty preferred. However, faculty proposals often reflected fear of scientific competition, family involvement, group interests and sheer vanity containing large salary claims. Althoff had observed that the procedure had not consistently led to the appointment of the most suitable candidates to German chairs. Once in the ministry, he started countering bad appointments and excessive financial claims. A too frequent change of job by some professors was countered by a contractual agreement to stay in the same position for three to five years in order to assure a minimal continuity of teaching. ${ }^{162}$

Althoff developed a system to improve the selection method of candidates. The major problem was to get better information about the performance of scholars. Without prejudice, he carefully evaluated the scientific production, the academic reputation, the teaching qualities and the character of candidates. Not all of this information was available through the official channels or in publication lists. All of the factors were observed by other scholars, who were not necessarily working at the same unversity.

161. Hubert Laitko (1989), Humboldt und Althoff, P. 12.

162. This clause was called the Reverse. 
This led to the most important role of the confidential network of academic agents: to provide Althoff with qualitative, recent and better information about the performance of scholars.

"... d das System Althoff wurde zu einem wesentlichen wenn nicht sogar Hauptteil I.. I mit seiner Personal-, Berufungs- und Besoldungspolitik identifiziert. Um sich in der Berufungspolitik, vor allem fur die Beurteilung der jeweiligen Fakultatsvorschlage, aber auch für die Vorbereitung und Oktroyierung eigener ministerieller Personalentscheidungen, wenn die Fakultäsvorschlage unzureichend erschienen, ein Hochstmaß an Personal- und Sachkenntnis zu sichern, baute Althoff bereits in den ersten Jahren seiner Tatigkeit ein weitverzweigtes System von Vertrauensleuten, von besten Fachkennern auf, von denen er sich auf 'verborgenen Wege', im persönlichen Gespräch oder schriftlich, natarlich zumeist vertraulich, in umfassender Weise beraten lie $\beta$. "16s

Observation 26: When Althoff appointed a member of the academic staff, he combined expert knowledge on the scientific situation of a discipline with accurate scholarly appraisals of the academic performance of the candidate.

Althoff made thousands of appointments, for which he did not rely automatically on the opinion of the local faculty. He listened to the judgements of experts, who were recognized top scholars in their discipline. Their opinions had to assure the objectivity of the appointment decision, which might be distorted by personal sympathies of faculty members. In turn, Althoff increased the objectivity of these subjective opinions by valuing independent, critical, fast and converging judgements, pointing out a candidate's abilities and weaknesses. Althoff also used comprehensive surveys on the scientific situation of a discipline, including a state-of-the-art assessment and an indication of promising progress and promising scholars. ${ }^{164}$ Combining all this information, he could accurately assess candidates.

Obtaining the expert information on the growing academic system was systematized in a network. It should be noted that the system only worked because the central receiver in the network (Althoff) knew how to operate it and skillfully processed the information.

Consider e.g. the appointment of David Hilbert and Ludwig Plate: In 1891, professor Felix Klein favored Arthur Schönflies (1853-1928) as his associate professor in Göttingen. ${ }^{165}$ But, in a letter to Althoff, he pointed out the qualities of a younger.

163. Günther Wendel (1991), Aktivitaten Althoffs, p. 124-125.

164. Althoff prepared appointment decisions years in advance. Most helpful in the long-term strategy were the confidential reports on. the scientific and scholarly situation of a entire discipline. Felix Klein, for example, wrote a report about mathematics: Akruelle Marhematische Lage. The professors Kayser from Marburg, von Koenen from Göttingen and Beyrich from Berlin investigated the "Quality of the Private Lecturers and Extraordinary Professors in the Field of Geology and Paleontology at Prussian Universities". Other reports, e.g. Wilhelm Foerster's, have been mentioned earlier.

165. Hubert Laitko (1989), Humboldt und Althoff. p. 10. 
even more brilliant scholar: David Hilbert (1862-1943). Klein argued that Hilbert, a true genius, would probably be stifled under his wings because he had all the capacities to become a full professor himself. Two years later, Althoff filled the chair of mathematics in Kōnigsberg with Hilbert, at the occassion of which he asked him to suggest some names for the associate professorship that was vacant as well. For the promotion of the Marburg lecturer in Zoology, Ludwig Plate (1862-1937), Althoff consulted the leading scholars. Carl Chun (1852-1914, Breslau), Franz Eilhard Schultze (1840-1921, Berlin), Ernst Ehlers (1835-1911, Göttingen), Carl Ludwig (1816-1895, Bonn) and Karl Mobbius (1825-1908, Berlin). ${ }^{106}$

Observation 27: Althoff respected the traditional academic rights as long as as they were not used for the protection of vested interests.

Personal sympathies could distort the information from the confidential academic agents as well, especially in appointment decisions. To generate knowledge that was as objective as possible, Althoff always contacted many different advisers. Their letters were secret and had to be returned fast, so that their opinions could not be influenced. Althoff checked their accuracy and speed of response. The letters had to include a statement about the position of the candidate in the academic community, his scientific development, his performance level, his character and his financial and personal situation.

When the independent judgements of the confidential experts unanimously pointed at one scholar, it was highly likely that he was the most suitable candidate. In furn, Althoff was suspicious if the faculty of a particular university suggested a candidate, whom members of the scientific community in that discipline would not even consider. By taking the approach of an integrated system, Althoff was in a position to interject competition from another candidate if a particular faculty unduly protected its own candidate or some vested interests. Differences of opinion between the experts did occur, of course, which sometimes required further investigations by Althoff and his staff. The confidential academic agents had one clear incentive to provide accurate information: abuse of trust implied exclusion from the network.

Althoff strongly defended academic freedom, ${ }^{16 \%}$ but also believed that universities were public institutes. Therefore, the government had to oversee their administration. In defending this policy, Althoff used an argument advanced long before by Wilhelm von Humboldt: state control reduced the likelihood that the development of individuals, faculties and institutions would be retarded by vested interests. ${ }^{168}$ While Althoff, looking for unanimous consent among scholars and cooperation instead of opposition from the academic establishment, fully respected the traditional academic rights, he did not yield to pressure out of fear for competition among faculty' nor to vested interests.

166. Gottfried Zirnstein (1991), Althoffs Wirken für die Biologie, p. 355.

167. See observation 31 .

168. John E. Craig (1984), Scholarship and Narion-Bullding, p. 93. 
Compared with previous administrators, Althoff made less use of the prerogative to appoint a professor in spite of the faculty's will. ${ }^{160}$ The influence of the Althoff system allowed the minimal use of this prerogative by promoting the most suitable candidate in the faculties through the agents, the resulting proposal being of course already in favor of Althoff's candidate.

The cases of Ulrich von Wilamowitz-Moellendorf and Victor Meyer are good illustrations of Althoff's practices. In December 1895, Hermann Diels (1848-1922) had informed Althoff that the Berlin professors Ernst Curtius (1814-1896), Adolf Kirchoff (1826-1906) and Johannes Vahlen (1850-1911) would oppose the intended appointment of Wilamowitz at their faculty. ${ }^{170}$ The reason was one to infuriate Althoff: fear of competition. When Curtius died eight months later, the vacant professorship was announced in such terms that only one scholar was capable of meeting the high requirements of the candidate profile: Wilamowitz. As a result, the Berlin faculty proposed his appointment to the Ministry of Culture on August 3, 1896.17

In 1884, the faculty of Göttingen preferred that Victor Meyer (1848-1897) from Zürich would succeed Hans Hübner (1837-1884), professor of chemistry, who had died. Other candidates on the faculty's list were Emil Fischer, Otto Wallach (18471931) and Ferdinand Tiemann (1848-1899). In order to make the right decision, Althoff also consulted Germany's leading researchers August Kekulé, Adolf' von Baeyer and August Wilhelm von Hofmann (1818-1892). All three preferred the Swiss. candidate as well. At the same time, they pointed out the capacities of the other three scholars, whom they considered' of high quality. ${ }^{172}$ As a result, the initial proposal from the faculty of Göttingen was accepted.

Observation 28: The attocratic "personal regime" of Althoff was not absolute.

The appointments of certain scholars show that Althoff swiftly had to operate within the limits imposed by other authorities. In spite of his autocratic style, Althoff's authority was constrained by the demands of the Court and public opinion and the rights of faculties as well.

The stiff resistance of the Berlin Faculty of History e.g. impeded the appointment of Karl Lamprecht (1856-1915) as the successor of Heinrich Treitschke (1834-1896).

169. Althoff overruled $16.5 \%$ of all faculty proposals, which was much less frequently than the preceding Assistant Secretary (27.9 \%). See: Bernhard vom Brocke (1980), Hochschul.. und Wissenschaftspolitik, p. 90.

170. Bärbel Boschan (1989), Philosophische Fakultat in Berlin, pp. 71-85.

171. William M. Calder (1991), "Die Rolle Friedrich Althoffs bei den Berufungen von Ulrich von Wilamowitz-Moellendorf", in: Bernhard vom Brocke (Hrsg.), Wissenschaftsgeschichte und Wissenschaftspolitik im Industriezeitalter, Verlag August Lax, Hildesheim, pp 251-266.

172. Hartmut Scholz (1989), "Friedrich Althoffs Einfluß auf die Entwicklung der Chemie in Deutschland Ende des 19. Jahrhunderts", in: I.T.W... Friedrich Althoff 1839-1908, Akademie der Wissenschaften der DDR, Berlin pp. 86-100. 
At the Emperor's request, a surgeon, who had successfully treated the Crown Prince, was appointed at the University of Halle in 1890. Althoff strongly preferred another candidate, but faculty put the blame on him. In 1900, professor Philipp Zorn (18501928) had to be transferred from Königsberg to Bonn at the demand of the Emperor in order to lecture the Crown Prince in constitutional law. The faculty in Bonn was discontent with this choice and, again, blamed Althoff.

In 1901, Althoff appointed Martin Spahn (1875-1945), 26 years old at the time, as professor of history and philosophy in Straßburg. The decision to set up a confessional chair and appoint a Catholic scholar made the Protestant community so furious that Althoff seriously feared for his own position.

\subsubsection{Researchers of Genius}

Althoff's human resource management was focused on the researchers of genius. He was convinced that the development of their talents was an important factor of scientific progress. Indeed, the AIthoff system promoted and attracted many top scholars, providing them with excellent research facilities and minimal teaching duties. Althoff furthered the career of top researchers like Emil Behring, Robert Koch, Paul Ehrlich, Heinrich Hertz (1857-1894), Emil Fischer, Gustav Schmoller, Johannes Haller (1865-1947), Ludwig Prandtl, Jacobus van 't Hoff (1852-1911) and Max Planck. He also supported great scholars and academic managers like Adolf Harnack, Felix Klein and Wilhelm Foerster.

Observation 29: Althoff not only appointed suitable candidates to existing chairs, he also created new positions with excellent research facilities in order to attract top scholars.

Althoff tried to lighten the teaching burden of Prussia's top scholars by granting them teaching privileges and research professorships. He lowered e.g. the teaching duties of Heinrich Hertz in Bonn (1889) and appointed professors to assist Behring in Marburg (1895) and Fischer in Berlin (1903). Althoff created the first research professorship at the Academy of Berlin. This new position, combined with an honorary professorship at the university, convinced the brilliant. Dutch professor Jacobus van 't Hoff to come to Berlin. ${ }^{173}$ Van 't Hoff had declined a previous offer to become full professor, because the teaching load would not have allowed him to carry on with his research program.

173. Van 't Hoff earned a yearly salary of 10,000 marks at the Academy' and had no teaching obligations at the university. After' van. 't Hoffs, death in 1913 and due to the mediation of Walther Nernst (1864-1941), Alfred Einstein (1879-1955) got the academy professorship, which was then financed by the Koppel Fund. Einstein earned 12,000 marks a year. See: Bernhard vom Brocke and Rudolf Vierhaus (1990), Forschung im Spannungsfeld, p. 86. 
The fundamental solution of the Althoff system was the creation of independent: research institutes directed by top scholars. ${ }^{174}$ The institutes were built around a scholar and set up in a way that satisfied the specific needs of the research program. In the traditional system, the positions were determined by the teaching programs and were filled with candidates who differed least from the ideal profile, whereas the research institutes were modeled after the research program and the scholar. ${ }^{175}$

To a certain extent, the emphasis on the talents of genius neglected the hard-working. yet less brilliant professors, who were engaged primarily in teaching and management activities. In Göttingen, the conflict between teaching and research was solved by having the top scholars give advanced seminars, while the repetitive element of education was left to the less research-minded professors.

\subsubsection{Minorities}

Academic performance and international recognition are two key words of the Althoff system. A third major principle was Althoff's policy of equal opportunity. He opened academic jobs for members of previously excluded minority groups like Catholics, Jews, Social-Democrats and atheists. He also upgraded the secondary education for girls, so that by 1908 German women were allowed to study at Prussian universities.

Observation 30: Althoff gave scholars who belonged to a minority group equal opportunities to an academic career.

The Social Democratic Party (SDP) was viewed by the Prussian authorities as a revolutionary and subversive party. Therefore membership was incompatible with an academic position because Prussian professors were state officials. ${ }^{176}$ However, the dissemination and discussion of socialist ideas at Prussian universities, called socialism-of-the-chair, was allowed by the Ministry of Culture. Althoff protected social thinkers like Werner Sombart (1863-1941), Ignaz Jastrow (1856-1932) and Heinrich Herkner (1863-1932), but was not able to protect active members of the SDP. Academic freedom was explicitly academic and did not extend to political behavior.

Private lecturers (Privatdozenten) were neither employed nor salaried by the Ministry of Culture. They were not civil servants, but were given the right to teach by the local university authorities. ${ }^{17}$ It was an important safeguard for academic freedom, because a professor, who was dismissed, could always become an unsalaried lecturer.

174. See observations 16 and 21 .

175. The Gottingen Association al'so created personal ordinary professorships, i.e. chairs linked to a particular scholar. When this chairholder died, the position was, liquidated or had to be reestablished. These positions were created for Emil Wiechert (1861-1928) in 1904 and for Ludwig Prandtl (1857-1953) and Hermann Theodor Simon, (1870-1918) in 1907.

176. Membership of the SDP implied serious sanctions, mostly dismissal.

177. The unsalaried lecturer had to live from. lecture fees and private wealth, or was supported by his spouse and family. 
However, in 1898, a bill was passed that allowed sanctions against private lecturers who were members of the SDP. 73 The first victim was the Berlin physicist, Leo Arons (1860-1919), Arons spelled out how Althoff supported him and how he managed to delay the approval of the lex Arons for at least another three years. ${ }^{17}$ When the law passed eventually, Althoff improved the legal and financial situation of the private lecturers, arguing that if they had to comply with the same rules and were given the same disciplinary sanctions as the rest of the state bureaucrats, the other regulations had to apply as well. ${ }^{100}$ Professor Hans Delbrück (1848-1929), who fell victim to a political trial set up by the Ministry of the Interior, ${ }^{13}$ also acknowledged Althoff's personal support and his struggle for academic freedom.

Catholics and Jews rarely became full professor at a. Prussian university, ${ }^{12}$ especially at Königsberg and Halle, which had been founded as Protestant universities. ${ }^{\text {Is }}$ Althoff considered it a shame how Catholics, Jews and other minorities were treated. He believed the Kulturkampf was political shortsightedness which he would not tolerate. So, Althoff took corrective action. Despite Protestant majorities in the faculties, he appointed suitable Catholic and Jewish scholars. IM Althoff's merit with respect to equal opportunity of minorities was widely acknowledged.

178. Gesetz betreffs die Disziplinarverhalmisse der Privatdozenten, better known as the lex Arons.

179. The lex Arons would never be used again afterwards.

180. Geserz betreffs die Dienstvergehen der nichurichterlichen Beamten (1852).

181. Delbrück had sharply criticized the German nationalist party in Posen and the Germanization policy in the region of Nordschleswig.

182. In 1880 , there were only 59 Catholic (or $14.86 \%$ ) and 11 Jewish (or $2.77 \%$ ) full professors in Prussia of a total number of 397. By 1896, their number had increased to 79 (or $16.84 \%$ ) and 17 (or $3.63 \%$ ) of a total. of 469 chairs. An estimated $60 \%$ of the population was Protestant, while $35 \%$ was Catholic. About $1 \%$ of the Prussian population practiced Judaism, but $10 \%$ of the student population was Jewish. Jewish scholars represented $15.5 \%$ of all private lecturers, which was no longer reflected in their share. of full and associate professorships. See: Bernhard vom Brocke (1980), Hochschul- und Wissenschaftspolitik, p. 85.

183. In. Strabburg as well, there were only two Catholic professors, as compared with 19 in the secular faculties, of Bonn and 14 in the secular faculties in Breslau. Founded by the Empire and administered by the Alsatian authorities, the Strafburg faculties had obtained a sort of unconditional right of proposal and presentation. Conscious of their relative independence from state control, they had exercised the right in a biased manner and without any regard for the conditions of the region. See: John. E. Craig, (1984). Scholarship and Nation-Building, p. 150.

184. Althoff appointed e.g. the Jewish professors Harry Bresslau (1848-1926) in Strabiburg and Hermann. Minkowski (1864-1909) in Gôttingen. Eugen Goldscheid (1850-1930), who made famous discoveries in nuclear physics, plasmaphysics and electronics, was appointed as the third observator at the Berlin Observatory. He was 45 years old, when he obtained his first job with income security. The Jewish Nobel Prize winner in Medicine, Paul Ehrlich, gratefully acknowledged that Althoff advanced his career and personal development. Althoff also supported many Catholic scholars, who were often. appointed at the Wilhelm-University of Münster in Westfalen. In 1893, Franz Hitze obtained a chair in Catholic sociology. In 1903. Althoff appointed the Thomistic philosopher Clemens Bãumker (1853-1924) as the successor of the famous Protestant and New-Kantian professor Wilhelm Windelband (1848-1915) at the University of Straßburg. 
"Keiner hat wie er [Althoff dazu beigetragen, die verbohrte Kulturkampfstimmung zu dampfen, welche fraher das ganze Ministerium fortriß. Er verhinderte mehr an kulturkamperischen Mißgriffen, als es ein halbes Dutzend katholischer Ratre vermocht hatten. "Is

Discrimation based on creed, beliefs and sex was gradually removed. In the archives of Columbia University. Senn discovered that Althoff agreed that creed should not influence the choice of exchange professors. ${ }^{\text {is }}$ With the support of his informal network, ${ }^{17}$ Althoff succeeded in appointing Schopenhauerian philosophers despite their atheistic convictions which clashed with the state's tradition as the defender of the Christian religion. ${ }^{1 \mathrm{k}}$ In 1908, German women were allowed to study at universities. Althoff had prepared this measure in three steps: by a mission of Felix: Klein to the United States, by allowing American women to study in Germany and by a reform of secondary education for girls.

\subsection{Academic Freedom}

Observation 31: The Ministry of Culture protected academic freedom as guaranteed by the constitution.

Academic freedom was guaranteed by the constitution of $1850 .{ }^{189}$ Many scholars pointed out that academic freedom was not endangered by the bureaucratic organization of the academic system. ${ }^{190}$ On the contrary, the Ministry of Culture effectively protected academic freedom and minority groups against oligarchic faculties, academic interest groups, political parties and government.

Of course, the state financed the academic system and the Althoff administration controlled academic appointments. This could always lead to conflicts with other academic authorities. Academic freedom came under serious pressure when the state dismissed Leo Arons (1860-1919). Nevertheless, Arons lost his job for his political activities, not for his academic publications or teaching.

Effective protection of academic freedom also means that alternative views can be advanced freely and that fear from competition is restrained. Althoffs equal opportunity policy protected academic freedom in a sense that minority groups often

185. Quoted from a 1928 speech of the Catholic MP Carl Bachem in: Bernhard vom Brocke (1980), Hochschul- und Wissenschaftspolitik, p. 87.

186. Peter Senn (1989), Where is Althoff?, p. 25.

187. Althoff's most prominent confidential agents in the field of philosophy were Wilhelm Dilthey (1833-1911), Benno Erdmann (1851-1921), Friedrich Paulsen (1846-1908), Hans. Vaihinger (1852-1933) and Eduard Zeller (1814-1908).

188. In 1889, Paul Deussen (1845-1919) became full professor at the Faculty of Philosophy in Kiel with Zeller's support. Deussen had been sanctioned before for being a scholar and defendant of the atheist theories of Arthur Schopenhauer (1788-1860).

189. Article 20: "Die Wissenschaft und Lehre sind frei."

190. See: Bernhard vom Brocke (1980), Hochschul- und Wissenschaftspolitik, pp. 7-119. 
hold minority views. The Ministry of Culture also followed the parity principle, which was aimed at creating an open-minded academic community. In Breslau, the leftist economist and social scientist Werner Sombart was appointed along with a conservative co-professor, Julius Wolf. ${ }^{191}$ According to the same principle, the liberal theologian Adolf Harnack had to work with an orthodox exegete, Adolph Schlatter in Berlin.

While Althoff believed that the public administration had a responsibility in countering vested interests retarding the performance of public institutions such as the universities, he was equally convinced of the importance of the autonomy of universities for the maintenance of academic freedom. Academic freedom, academic self-management and public administration were considered a healthful combination for an academic system to function well and to rule out abuses.

In 1901, Assistant Secretary (Sektionsrat) Karl von Kelle (1859-1935) was the first delegate of the Austrian Ministry of Culture, who participated at the conference on university affairs for German and Austrian officials, organized by Althoff. Kelle was astonished about the degree of autonomy given to the universities by the German administrations, ${ }^{192}$ whereas Austrian universities and scholars were used by the administration in Vienna for internal political purposes. As long as university rights such as the cooptation right were not abused to protect vested interests, there was considerable room for scholarly initiatives in Germany.

\subsection{Financial Resources}

When Althoff started his reforms, the academic system was almost fully financed by the Prussian state. Although public expenditures in real terms more than doubled between 1882 and $1907,{ }^{193}$ the continuous expansion of the academic system and the changing organization of research necessitated new ways of financing. The equipment for new lines of research, especially in the natural sciences, was very expensive. ${ }^{194}$ Building on his confidential network, Althoff set up an innovative multi-source financing system, in which the Prussian state, local authorities, academies, industry, banking and private sponsors participated.

191. Strafprofessur or punishment professorship.

192. Walter Hoflechner (1991), "Zum Einflub des deutschen Hochschulwesens auf Österreich in den Jahren 1875-1914", in: Bernhard vom Brocke (Hrsg.), Wissenschaftsgeschichte und Wissenschaftspolitik im Industriezeitalter, Verlag August Lax, Hildesheim, p. 156.

193. See observation 14.

194. The chemical institute of Emil Fischer e.g. was very expensive. The buildings cost $1,380,000$ marks, the research instruments 121,000 marks and the yearly budget amounted to 78,150 marks. The average budget of an institute for physics at a university was 14,500 marks; a chemical institute had to operate on 37,000 marks. The total budget of all 21 German seminars of history together was 29,000 marks. See: Bernhard vom Brocke and Rudolf Vierhaus (1990), Forschung im Spannungsfeld, p. 86. 
Observation 32: Althoff built a multi-source financing system for the academic system.

\subsubsection{Prussian Ministry of Finance}

Althoff visited the Ministers of Finance, Adolf Scholz (1833-1924) and later Johannes Miquel (1828-1901), even at their holiday resorts to ask for additional funds. Miquel admitted that Althoff was extremely well prepared for the budget talks. Gustav Schmoller, who was on friendly terms with Miquel and Althoff, played an important intermediary role in the process. ${ }^{195}$

With creativity and opportunism, Althoff looked for additional financial means. He used the boycott of the Charite-Hospital by the Health Insurance Funds and the Social Democrats to obtain more state funds for the reorganization of the famous hospital. In 1887, he convinced a wealthy, retired extraordinary professor in medecine, Otto Körner, to renounce his pension in exchange for the unsalaried title of honorary professor. With this money, Althoff financed a new chair in ear-, nose-and throatdiseases at the University of Marburg behind the back of the Minister of Finance. ${ }^{190}$ In comparison with Austria, the Prussian Ministry of Culture could react rapidly and effectively in negotiations with future chairholders about working conditions and financial compensation.

In order to finance new academic disciplines and to help Germany gain and retain international recognition, the Ministry of Culture renounced the monopoly it had held so far in the almost exclusively government-supported academic system. ${ }^{197}$ The novel course adopted by Althoff was a multi-source financing of science and scholarship.

195. Nicholas Balabikins (1989), From Schmoller to Althoff: Creating of a New Environment for Teaching and Research in Strassburg, 1872-1882, Paper Althoff Conference, Heilbronn, $16 \mathrm{pp}$. As mentioned earlier, Wilhelm Foerster was Althoff's liaison to the previous Minister of Finance, Adolf von Scholz.

196. Bernhard vom Brocke (1981a), Preußische Bildungspolitik, p. 742.

197. Examples are the University of Straßburg reopened by the German Empire, the University of Frankfurt founded by the city of Frankfurt and the local chamber of commerce, the KaiserWilhelm-Gesellschaft administered by the state and industry. 


\subsubsection{Local Authorities, Chambers of Commerce and Academies}

Local authorities were invited to participate in the foundation of research institutes and universities. They set up academies for practical medicine, business schools and academies for local public administration. ${ }^{195}$ The business schools were co-financed by local authorities and chambers of commerce. ${ }^{19}$ The first privately endowed university of Germany in Frankfurt, that utilized the financial capacity of that local community, was thoroughly prepared by Althoff and Frankfurt's mayor, Franz Adickes (1846-1915). ${ }^{200}$

Althoff created the first research professorships with the financial help of the Prussian academy of science. This practice was rather unusual, since academies used to be scientific clubs without a specific research task or any significant administrative staff. The academy professorship of Jacobus van 't Hoff, which was later occupied by Albert Einstein, has already been mentioned. Another example is Von der Gabelentz. ${ }^{201}$

198. Academies for local public administration were set up by the cities of Leipzig (1898), Köln (1901), Frankfurt a.M. (1901), Berlin (1906), Mannheim (1908), and München (1910).

199. The Berlin Business School was financed entirely by the local chamber of commerce, which was the oldest in Germany. The Business School of Frankfurt. was founded at the initiative of the local chamber of commerce, the steel industrialist Wilthelm Merton (1848-1916) and mayor Franz Adickes, in close cooperation with Althoff. The school prepared the foundation of the private university of Frankfurt. Most of the financial means were raised by wealthy citizens of Frankfurt (Wilhelm Merton, Gẹorg Speyer (1835-1902), Jacob Schiff (1847-1920), Mathilde von Rothschild).

200. At the start in 1914, the University of Frankfurt a.M. had a working capital of 15 million marks.

201. The Leipzig professor Hans Georg von der Gabelentz. (1840-1893) was a scholar of international reputation. Althoff offered' him a chair in east asian languages in Berlin, although initially there was only budgetary room for an extraordinary professorship. When the negotiations with the Ministry of Finance about budgetary increases for wage purposes failed, Althoff turned to the academy members Theodor Mommsen (1817-1903) and Johannes Schmidt (1843-1901). The Prussian academy of science agreed to pay von der Gabelentz a salary on the condition he came to Berlin on a permanent basis. Von der Gabelentz accepted Althoff's offer and became an unsalaried ordinary professor of sinology at the university and a salaried member of the academy. See also: Bärbel Boschan (1989), Philosophische Fakultat in Berlin, pp. 71-85. 


\subsubsection{Industry and Banking}

Scientific developments and the growing demand for knowledge had led to an innovative institutional response: independent research institutes. Their survival necessitated innovations in the financing of research as well. The research institutes brought about joint financing schemes, which resulted in a closer co-operation of public administration, industry and banks. Althoff was an excellent fund-raiser ${ }^{2 m}$ The Dahlem project, worked out in the Kaiser-Wilhelm-Gesellschaft after his death, reinforced the innovative alliance of science, state and industry that was brought into being by Althoff.

Two early examples of mixed public-industrial financing were the Institute for Sugar Research, which was a chemical laboratory set up by the Society of the Sugar Beet Industry in 1866, and the Institute for Industrial Fermentation, which had been founded by the Society of Alcohol Producers in 1874 and which served as a experimental station for distillation. In both cases, the state provided buildings and grounds, the industry financed the research infrastructure of the institute. ${ }^{203}$ However, they were not fully independent, but affiliated to the Agricultural University of Poppelsdorf-Bonn.

The first independent organization was the PTR (1887). The financial means largely came from private resources, in particular from Werner Siemens (1816-1892). The budget was administered by the Ministry of Culture. In Frankfurt, Paul Ehrlich's institute was financed by the city, the Speyer Bank and two chemical firms, Cassela and Hoechst. Emil Behring worked with the Hoechst corporation as well, which was represented by August Laubenheimer (1848-1904). The captain-of-industry, Henry Böttinger (1848-1920) and the large enterprises of Bayer and Krupp financed the Göttingen Association. ${ }^{204}$ Multiple financial sources were tapped to set up most institutes.

\subsubsection{Private Foundations}

Before 1900, there was only one large private foundation. ${ }^{205}$ It financed the scientific publications of academy members in Berlin. After the turn of the century, there was a proliferation of private foundations and money-raising organizations for scientific purposes. Rasch asserts that the Prussian Ministry of Culture tried to prevent these resources from ending up in unsubstantial funds by putting these

202. For example, in four months time, Althoff persuaded German sponsors to grant a total of 1.5 million marks for the Empress Friedrich Institute for Postgraduate Education in Medicine in Berlin, which opened its doors in March 1906.

203. Bernhard vom Brocke and Rudolf Vierhaus, (1990), Forschung im Spannungsfeld, p. 90.

204. Friedrich Bayer (1851-1920), manager of the famous paint factories, became interested in the financing of academic research by way of his father-in-law Henry Böttinger.

205. The Hermann und Elise, geborene Heckmann. Wenrzel Sriffung was created in 1894 with an endowed capital of 1.5 million marks. 
initiatives under central administration. ${ }^{206}$ This danger was present e.g. in the state of Baden, where the famous professor Vincenz Czerny (1842-1916) could hardly raise the money to set up his Institute for Experimental Cancer Rescarch in Heidelberg. The Prussian approach led to the foundation of the Kaiser-Wilhelm-Gesellschaft in $1911^{207}$

Private financing was a perfect way of advancing science without putting a burden on the state budget. After 1900, the number of private foundations increased rapidly, A large foundation for the advancement of scientific research was the Gottingen Association mentioned earlier, which concentrated its efforts on applied mathematics and physics. ${ }^{200}$ The Koppel Foundation "for the Promotion of Cultural and Scientific Relations Between Germany and the United States but also with Other Culturally Important Countries, Particularly France" was a one million mark fund, set up by the Jewish banker and industrialist, Leopold Koppel (1854-1933) in 1905. Among other projects, it financed the weekly "International Journal for Science, Culture and Technology", the German Medical School in Shanghai, the German-Chinese College in Tsingtao and part of the international professorial exchanges.

Some fund raising organizations were the Straßburg Scientific Society (1906), the Rhine Society for Scientific Research in Bonn (1907) and the Organization "Chemical State Institute", that raised one million marks in 1908 toward the creation of a chemical institute in Berlin. The Friedrich Althoff Foundation gathered 200,000 marks for all kinds of scientific purposes. It was established after Althoff's death "but

206. Manfred Rasch. (1990), Thesen zur Preußischen Wissenschaftspolitik, p. 241.

207. In. 1911, the Kaiser-Wilhelm-Gesellschaft disposed of 15 million marks, which came from private sponsors, industrialists, bankers and the state.

208. Private foundations were established for specific purposes, e.g. by Joseph Florimond, Duke of Loubat for a chair of American studies at the University of Berlin (1900, 300,000 marks), Gustav Mevissen for the Business School in Koin (1901, 1 million marks), Wilheim Merton for the Business School of Frankfurt (1901, 2.1 million marks), Georg and Franziska Speyer and Lucius Meister for chairs at the Business School of Frankfurt (1901, I million and 500,000 marks). Carl Christian Jügel for an auditorium and professorships of philosophy in Frankfurt (1903, 2 million marks), Otto and Ida Braunsfels (for a pediatric hospital in Frankfurt, 1904, 150,000 marks). Edmund Siemers for an auditorium in Hamburg (1907), Henry Bōttinger (for a house for foreign students in Berlin, 1908), Eugen Tornow (for a chair in natural sciences, Frankfurt, 1908), Heinrich Lanz (for the Business School of Mannheim, 1909), James Speyer (America Institute in Berlin, 1910), Jacob H. Schiff (chairs of social economics and semitic philology in Frankfurt, 1910). Arthur von Weinberg (chair of physics in. Frankfurt, 1910), Hans Meyer (chair of colonial geography at the University of Berlin, 1910), the Rothschild family (preparation of the University of Frankfurt, 1913) and professor Cuny (financial aid for the research of lecturers at the University of Berlin, 1914, 200,000 marks according to his last will). Other funds were created among others by Theodor Stern (for general medical purposes, 1901, 700,000 marks) and Rudolf Virchow (for general scientific purposes, 1903, 200,000 marks).

209. Other large foundations were the 1.8 million marks Jubilee Fund of the German Industry created in 1899 for the advancement of technical sciences, the Hamburg Scientific Foundation of 1907 with a capital of 4 million marks and the Robert Bosch Foundation for the Technical College of Stuttgart, set up in 1910 (1 million marks). 
was more important as a forum where the founders of the Kaiser-Wilhelm-Gesellschaft would meet.

The directors administered the institutes, while the public administration acted as the legal and effective safeguard of academic freedom against the commercial pressure from the private sponsors. Sponsors could not determine the academic policy of the institute they were financing, but, along with state officials and professors, they were represented on the board to check potential waste of money.

\subsubsection{Incentives to Finance Academic Research}

Kahlow correctly points out that the technical colleges - with university status since 1899 - and the applied research institutes have stimulated the initial interest of industry and private sponsors to take part in the promotion of science and the financing of the academic system. In this respect, Althoff furthered the development of basic research by supporting the technical and applied sciences. ${ }^{210}$

Observation 33: Orders, ennoblement and licences were specific incentives to attract private money for academic research.

Althoff used several incentives to tap private resources for public purposes. Two specific instruments were the conferment of orders and ennoblement in exchange for financial support. Since Althoff did not have the authority to confer orders or ennoble persons, he had to persuade others to do so.

Consider the examples of August Scherl and Henry Böttinger. In exchange for the Red Eagle, a prestigious Prussian mark of honor, the publisher August Scherl (1849. 1921) made a contribution of 100,000 marks, which solved the deficit for the construction of the Marburg Polyclinic. ${ }^{211}$ The invitation to donate 100,000 marks for a house for foreign students in Göttingen was phrased in such terms that Henry Böttinger felt honored to be chosen as sponsor. Later, Althoff arranged a heritable noble title for Henry Böttinger. Ennoblement was a crucial step in social climbing and was an important incentive for members of minorities.

Licences were an important incentive for corporations to grant financial support. At his Institute for Experimental Therapy and Hygiene in Marburg, Emil Behring continued research on diphteria and looked for serums for tuberculosis. The institute

210. Andreas Kahlow (1989), "Der Technikerstreit im letzten Drittel des 19. Jahrhunderts", in: I.T.W., Friedrich Althoff 1839-1908, Akademie der Wissenschaften der DDR, p. 126.

211. Althoff used. tactical means to finance the Marburg clinic. He promised his colleague Franz Böhm in Baden not to issue a call to Berlin (Prussia) for a famous professor, who was working at the University of Heidelberg (Baden). In return, the state of Baden had to grant the "Zahringer Lion" to August Scherl. At that time, the German Emperor could not grant a mark of honor that was less prestigious than the Baden Lion. So, the Emperor granted Scherl the "Red Eagle", which was a much more prestigious mark of honor than he initially had wanted to give. 
was financed by the Hoechst corporation. In return, Hoechst obtained the licence to mass produce the serum. This was clearly in the interest of Hoechst, but also of public health because the Prussian state set the price of the anti-diphteria serum. 


\section{Scholarly Behavior and Academic Institutions}

6.1. Scientific Community

Assumption 3: The scientific community is an informal social organization that coordinates the activities. of scholars.

Ass. 4: The auditing procedures of the scientific community consist of the continuing and alternating process of verification and dissemination of academic output.

\subsubsection{Verification}

Proposition 1: The auditing and disciplinary procedures of the scientific community exert such pressure on the scholars that it brings about a high level of quality and accuracy in academic output.

Prop. 2: The scientific community generates and stores information about the value of academic output.

\subsubsection{Dissemination}

Prop. 3: Dissemination of scientific knowledge is a necessary condition for the audit of academic output by the scientific community.

Prop. 4: Well-organized libraries may improve academic performance by lowering the search costs of scholars and by facilitating the dissemination of scientific knowledge.

Hypothesis 1: The Althoff system stimulated academic performance by keeping the scientific community open and by improving the dissemination of knowledge. 


\subsection{Transaction Costs of Academic Production}

Prop. 5: The transactional characteristics of academic production reveal a need for a specific academic governance structure.

Ass. 5: Transaction costs consist of the costs of information gathering. contracting and monitoring.

Prop. 6: Monitoring academic production by using the market entails substantial transaction costs.

Prop. 7: The voluntary auditing procedures of the scientific community may lower the monitoring costs of academic production.

Hyp. 2: The Althoff system created a transaction-specific governance structure for academic production.

\subsection{Property Rights}

6.3.1. Externalities

Hyp. 3: The hierarchical Althoff system captured more free externalities of academic production than the decentralized academic system.

6.3.2. Principal-Agent Relations

6.3.3. Academic Organization

Prop. 8: The faculty system is patterned after the needs of the educational system and of individual research activity.

Prop. 9: Research institutes are patterned after the needs of academic team production.

Prop. 10: The ultimate control of the academic output of an institute remains with the scientific community although team production clearly offers internal monitoring advantages.

Hyp. 4: Althoff's independent research institutes and seminars stimulated formal academic team production.

Prop. 11: The evaluation of academic output as an instrument of control should be the rule, evaluation of input behavior the exception. 


\section{Scholarly Behavior and Academic Institutions}

The Althoff system is basically a set of institutional reforms and specific management methods that were aimed at improving the performance of the Prussian and German academic system. But how exactly did these reforms and methods influence academic performance? The economic analysis builds on a model of the behavior and interaction of scholars and tries to show how changes in incentives and constraints, which are determined by the academic institutional setting, affect their performance.

\subsection{Scientific Community}

In his seminal work, Gordon Tullock provides a simple micro-economic model of scholarly behavior. ${ }^{212}$ Two basic motives for doing academic research enter the utility function of scholars: curiosity and personal income or wealth. ${ }^{213}$ Scholars may engage in scientific activity as a hobby, i.e. motivated by pure curiosity, or they may pursue research simply for their living, which is an induced type of curiosity. A distinction is also made between basic research, which is primarily motivated by general curiosity, and applied research, which is motivated mainly by a desire to obtain practical objectives and applications. The curiosity of scholars is subject to social guidance. The information inputs from other scholars are important in shaping the problems which they investigate. Scholars read each other's articles (even of those who lived long ago), and this influences their work. In turn, they are interested in the approval of other scholars and consciously shape their research into projects which satisfy the curiosity of other researchers as well as their own. If the system works well, scholarly resources are allocated efficiently because information about the benefits of employing resources in alternative uses is generated and persons are motivated to take account of this information.

Assumption 3: The scientific community is an informal social organization that coordinates the activities of scholars.

The social guidance of scholars takes place in the scientific community. ${ }^{214}$ It is an informal system of voluntary cooperation, in which the individual scholar freely seeks his own ends, but which leads him also to serve the ends of the others. Basically, it

212. Gordon Tullock (1966), The Organizarion of Inquiry, Dụke University Press, Dưrham N.C..

213. Although various other considerations may motivate scholars, Tullock argues that the motive of pure and induced curiosity to obtain general and practical information is more intense among. scientists, than among the rest of the population.

214. It should be noted that the term scientific communiry is used to describe the scientific communiries specialized by fields. 
coordinates the activity of scholars. Tullock argues that the extraordinary level of reliability of academic output, the extreme precautions to insure accuracy and the restraints from faking scientific results lie in the organization of the scientific community.

"The purpose $[.$.$] is to investigate the nature of this scientific community and to.$ make a start on explaining why it is such a successful social instrumentality - to explain why the individual scientist, who feels quite free and unconstrained, is. nevertheless led to investigate problems of interest to others, and how, without any conscious intention, he exerts influence on the research done by other scientists. Scientists are contributing to an essentially cooperative activity. "ais

"/The scientific communiry] is an organizational system which takes these rather normal human beings /scholars/ and uses them to produce knowledge of a very high degree of reliability. ${ }^{216}$

Assumption 4: The auditing procedures of the scientific community consist of the continuing and alternating process of verification and dissemination of academic output.

\subsubsection{Verification}

When a scholar believes he has developed a new scientific theory, he normally verifies his research results by searching for new evidence which may contradict or verify his theory. The process of checking a theory consists of collecting new data ${ }^{217}$ When the theory clashes with the new evidence gathered, it is ruled out by the technique of falsification. But, being assured of the accuracy of the theory, he typically publishes his results in a book or article. ${ }^{218}$ After the initial dissemination, the verification process by other scholars starts. Two techniques are used, repetition and discussion, ${ }^{219}$ which, in turn, promote the dissemination of scientific

215. Gordon Tullock (1966), Organization of Inquiry, p. 8.

216. ibidem, p. 160.

217. In the development of a new technology, a scholar typically runs various tests of the instrument, in which the new technology is used. He also collects new empirical data to verify his research results.

218. Dissemination of a new technology takes place when a new good using the technology, is manufactured and marketed

219. Scholars repeat research to detect and prevent false discoveries, which may be caused by deliberate fraud, subconscious bias and pure accident. The risk of detection is correlated with the alleged importance of the discovery. Therefore, research results that claim to have a significant impact on scientific progress, are more likely to be repeated. Some scholars, may completely repeat research experiments or the reasoning of a. new theory, e.g. for teaching purposes or when the use of it has failed to work. By doing so, they may notice errors and report them. Repetition rules out most scientific falsities. Therefore, scholars have more confidence in working with results that have been repeatedly tested, because it decreases the probability of untruthfulness. In turn, they are sceptical about non-repeated experiments, which 
knowledge. Repetition rules out most of the scientific falsities that may be caused by deliberate fraud, subconscious bias or pure accident. Since the risk of detection is correlated with the importance of the discovery, major impediments to scientific progress are more likely to be detected by other scholars.

Proposition 1: The auditing and disciplinary procedures of the scientific community exert such pressure on the scholars that it brings about a high level of quality and accuracy in academic output.

By their very nature, the pure-curiosity scholars are only interested in the truth. Therefore, they are likely to make considerable efforts to rule out most of the inaccuracies in their work. The induced-curiosity scholars, however, may well produce anything that their non-expert employers buy. ${ }^{200}$ This would create a serious problem for the institutes that employ this type of researchers, and would be an impediment to scientific progress. However, all' scholars are subject to the strong social control of the scientific community, which forces them to work accurately and to search for the truth.

Tullock has argued that the accuracy and quality of academic production is simply the outcome of the social environment in which scientists operate. The scientific community counts among its members applied researchers and pure-curiosity scholars. The former may waste valuable time and effort in trying to develop practical applications of inaccurate or wrong theories, while the latter cannot make the desired scientific progress. When the use of the original results fails, it reduces their research productivity. Therefore, they are likely to report and protest this failure. Applied researchers, however, are particularly likely to emphasize truth and protest false discoveries. Subject to economic pressures, they have an incentive in developing their products with a minimum waste of time. Consequently, a large part of the scientific community is likely to be highly impatient with errors. Also basic researchers find their academic output, personal income and promotion chances reduced, when they have engaged in research that started from the wrong premises. To the extent that the discovery of the falsity in itself is a major scientific achievement, they are likely to report the disproof carefully. Because scholars make use of new inventions in numerous and unpredictable ways, the chances that fraudulent or inaccurate research is detected, would appear to be high.

The scientific community not only uses effective auditing procedures, it has an even severer disciplinary system. While the discovery of important phenomena normally greatly improves a scholar's prospects in terms of personal income, academic promotion and access to research facilities, the failure of research results is likely to

219....

they probably repeat themselves when they want to set up new promising lines of research in their own discipline. In addition to repetition, there is formal and informal discussion of scientific. issues. This may have considerable clarifying and stimulating effects leading to new discoveries, but it may also be pure waste of academic time and resources.

220. Their personal income being an increasing function of the amount of research output. 
have a pronounced negative effect on his career. When academic fraud is detected, the scholar may well find his reputation demolished. He can expect to lose his position, to be unable to get another academic job in his field and to find that the learned journals are no longer interested in publishing his scholarly articles. The scholar, whose income is correlated to his results, might get tempted to come up with results by fakery. However, the probable long run effects of such fakery would be detrimental to his career. Therefore, induced-curiosity scholars are held to fairly high standards.

These standards are also implemented by mutual indoctrination of the moral principles of science. The main reliance is not on indoctrination, but on a system, namely membership of the scientific community, which makes it unprofitable to violate the principle tenets of scientific honesty.

"The scientist considering some problem knows that his conclusions will not only be formally tested by repetition and discussion, but also that other scientists will make use of them in unpredictable ways and that failure of his results under these conditions will reflect on him. It is hard to think of a stronger disciplinary system, "azi

Nevertheless, scholars make mistakes and sometimes they are prejudiced. Because they present their work for a large and highly qualified audience, which has an almost exclusive interest in the truth, scholars are likely to obey the standards of the informal organization, of which they want to become recognized members. Other human motives like vanity, political ideology or devotion to own ideas, do account for temporary deviations. But the auditing and disciplinary procedures of the scientific community are likely to result in the correction of these errors by other scholars.

Proposition 2: The scientific community generates and stores information about the value of academic output.

When the use of a scientific idea has failed to give the expected outcome, researchers. will explicitly verify the original insight, taking a closer look at the original reasoning. and methods or trying to regenerate the original data. But most of the time, they verify original insights in an implicit way, simply by using them in their own. research. Applied researchers e.g. do not want to waste time and effort with verifying. the theoretical basis of their research. They just want to make applications that work and use the available paradigms. But by using several theories to develop new applications, they actually test and verify the validity of these theories all the time. This constant use of scientific results by other scholars increases the probability of the truthfulness of the original results. By their own activity, scholars constantly verify the scientific ideas of other scholars. From this, it follows that the evaluation of scientific output is an essential part of the academic activity. The knowledge is stored in the minds of the scholars that compose the scientific community.

221. Gordon Tullock (1966), Organization of Inquiry, p. 163. 
While original ideas are explicitly checked for their accuracy, a lot of verification takes place as a free by-product of scientific activity. Applied research plays an essential role in the evaluation of academic output. For that reason, applied researchers have to be recognized members of the scientific community. Sometimes a tree of knowledge is drawn which is used to prove that basic research is more important than applied. However, since almost any discovery has another as its root, this kind of argument, justifying one type of research over another, is really weak.

\subsubsection{Dissemination}

Proposition 3: Dissemination of scientific knowledge is a necessary condition for the effective audit of academic output by the scientific community.

The verification process is integrated with the dissemination of the scientific knowledge. Research output must be disseminated to other scholars, before they can repeat or apply it, which then leads to further dissemination. The first step is usually the publication and the reading of the article. The second step consists in filing the information so that it can be found by other scholars. Each research project may set off several lines of research until the original work is disproved. Therefore, dissemination of scientific knowledge is a necessary, but insufficient condition for verification. When a scholar is assured that he has made a significant discovery, he usually publishes it in a learned journal or presents a paper at a conference. A more specific method for the dissemination of applied research is the patented production of a product which incorporates the newly discovered technology.

The volume or availability of publications should not make it impossible for a scholar to cover his field or at least a large part of it. When the situation occurs that articles are not read, it substantially affects the nature of the scientific process just described. It makes it more conceivable e.g. that errors remain unnoticed because the work is not repeated or applied. Scholars may get away more easily with fraud for a while. When a scholar's career prospects are primarily determined by the number of articles he produces, another significant effect is that the average article may not actually increase human knowledge. ${ }^{m}$

Proposition 4: Well-organized libraries may improve academic performance by lowering the search costs of scholars and by facilitating the dissemination of scientific knowlẹge.

222. Therefore, there should be some minimum requirements for publication. In this respect, the quality of editorial work is essential for a discipline. There is a clear incentive for editors to seriously evaluate research output, because the prestige of the journal and the reputation of the editors are largely determined by the opinion of the professional community, which evaluates the journal mostly on its contents. To maintain several journals is a necessary safeguard for original ideas and important contributions, which are turned down by mistake by one journal. The fact that each journal considers an article separately is of the utmost importance from the standpoint of giving new ideas an opportunity. 
Most of the information a scholar possesses is the result of formal education and selfeducation. ${ }^{23}$ The latter is the principal factor in the work of a scholar. ${ }^{224}$ In this respect, libraries function as storages of accumulated facts that provide a partial solution to the limited capacity of the human mind. In helping to make information available, they satisfy a necessary condition for the scientific auditing system, ${ }^{25}$ but also help scholars to form new theories and invent new instruments.

The greater the speed with which a scholar can find what is already known about a subject and the greater the security he can feel that he has actually found everything, the better the system works. By consulting previous work of other scholars, he can save time and use it to study a new problem. The library system has its limitations though. The improvement of filing systems depends on the amount of resources to be invested. There is also the difficulty of predicting the information wanted by future scholars.

A scholar continues his search of the literature until he finds some information or until he has exhausted the available material and returns to direct research. Because the classification of knowledge influences his search efforts and results, cataloguing is an important part and objective of scientific activity, which affects the performance of scholars. All unnecessary information must be excluded so that the scholar has a manageable job of self-education by depending on a reliable filing system. Normally, the initial exclusion process has already taken place at the publication level. The cataloguing system utilizes a further stage of exclusion because fields of knowledge may be rather arbitrarily defined, using mostly historical subject categories and terms. Crossfiling must exist to allow, for example, engineers to find information in the traditional sciences. Improving the library and cataloguing system is likely to reduce the search costs of academic production.

Hypothesis 1: The Althoff system stimulated academic performance by keeping the scientific community open and by improving the dissemination of knowledge.

The vital role of the scientific community lies in the production, verification and dissemination of scientific knowledge, in which applied researchers play a crucial part. Althoff took structural measures that improved the working of the scientific community. By granting the technical colleges the right to confer doctoral degrees, engineers became emancipated members of the academic community. By combining the findings of different traditional disciplines, they made essential contributions to the verification of scientific knowledge. In this respect, many of the independent

223. As well as the result of accident:

224. Productive scholars are likely to have a large part of their knowledge as the result of selfeducation, because formally taught knowledge is rapidly out of date. The self-education process turns on three sources: learned journals, scientific publications and conferences. The learned journals disseminate new theories and serve as a file. Books often put information, which thas been available for some time, in a broader framework. In spite of the more social character of certain meetings, a good deal of genuine professional discussion goes on at scientific conferences.

225. Cfr. proposition 3. 
research institutes, especially the Gôttingen Association for the Promotion of the Practical Use of Mathematics and Physics, played a similar role. To function well, the scientific community has to remain critical and open for new ideas. The international professorial exchanges were just one way to obtain this goal ${ }^{20}$ Along with a principle of moral justice. Althoff gave scholars of minority groups such as Jews, Catholics, Social Democrats and Schopenhauerians equal opportunities for an academic career. ${ }^{27}$ These minorities often held minority views, which encouraged their opponents to remain extremely critical and accurate about their own theories. The appointment of co-professors who held opposing view-points was another measure to acquire some heterogeneity in the homogeneous (Protestant) faculties.

Althoff consistently improved the dissemination of scientific knowledge, which is a necessary precondition for effective verification. In spite of much resistance. Althoff introduced e.g. the requirement that a doctoral examination included a printed version of the dissertation. ${ }^{23}$ The German Economic Policy Association ${ }^{229}$ published the discussion papers so that the information from the scholarly debate was not lost. On a larger scale, Althoff pushed the modernization of the library system in Prussia in two ways. He expanded the system and reorganized it. Althoff created e.g. an academic education and career for librarians. Scarce resources necessitated a policy of Schwerpunkabildung for the library system as well. Therefore, an inter-library loan system was established. This necessitated a uniform cataloguing system for Germany, which, in turn, lowered the search time of scholars.

\subsection{Transaction Costs of Academic Production}

The Althoff system improved the informal organization of science and scholarship. But how did the formal framework influence the academic performance of Prussian scholars? Was the bureaucratic and centralized academic system an efficient response to the needs of academic production?

The emergence of firms and bureaucracies has been explained by a kind of market failure, namely transaction costs. ${ }^{230}$ Consider the following example. In theory, employers could go to the market and negotiate a contract over every single task. However, it might cost too much to contract out each task whenever it has to be performed. Then, employers rationally forgo the use of the (labor) market. By. making long-term deals with employees, they save on the transaction costs of searching a qualified candidate every time and drawing up a. labor contract for each specific task. All long-term contracts are bundled in a hierarchical organization, where employees are paid to perform their job as their superiors and employers instruct them. It has been argued that bounded rationality and opportunism are the main

226. See observation 23 .

227. See observation 30 .

228. See observation. 19.

229. Verein fur Socialpolitik.

230. Ronald Coase (1937), The Nature of the Firm. 
sources of transaction costs. ${ }^{211}$ Bounded rationality means that economic agents have limited resources to gather information and limited ability to process it. Insofar as it is costly for other agents to know and assess the behavior of these agents, selfinterest drives them to act opportunisticly. ${ }^{232}$ Transaction costs are then associated with the containment of opportunism. The degree to which resources are vulnerable to opportunism depends to a large extent on the transaction cost of monitoring.

Proposition 5: The transactional characteristics of academic production reveal a need for a specific academic governance structure.

Three dimensions can be distinguished when describing transactions: the frequency with which they take place, the degree of idiosyncracy involved in the investments that are made for the transactions and the degree of uncertainty about the outcome of the transactions. They apply to transactions of all kinds. The more transactions are recurrent, entail idiosyncratic investments and are executed under great uncertainty, the more need for a transaction-specific governance structure there is for transactions to take place at all. ${ }^{23}$ Many academic institutes employ scholars on a long-term basis. Their production entails very specific investments in both human and physical capital. By its very nature, research is carried out under great uncertainty about its outcome. To be efficient, the academic system should try to match its organizational form with these transactional attributes. Otherwise, transactions costs are likely to become prohibitive. Institutions are particularly important in an environment of costly transactions and asymmetrical information. ${ }^{234}$ In general, the transaction cost approach argues that efficiency can be improved by establishing an organization that saves on the costs of using the markets. ${ }^{235}$

Assumption 5: Transaction costs consist of the costs of information gathering, contracting and monitoring.

The distinction between transaction costs and production costs can be particulariy hard to make. Following Crocker, ${ }^{236}$ it has become customary in the literature on transactions cost to distinguish between the costs of contracting, the costs of

231. Oliver E. Williamson (1985), The Economic Institutions of Capitalism.

232. Opportunism is more than the propensity to mislead and distort. Due to the different interpretation of limited or asymmetrical information, honest disagreements can also occur.

233. Oliver E. Williamson (1979) , "Transaction-Cost Economics: The Governance of Contractual Relations, Journal of Law and Economics 22, no. 1, p. 259.

234. Institutions are unnecessary in a world of complete and costless information. Without information, negotiating and policing costs, coordination could be perfectly decentralized, because shirking and free-riding would be detected immediately.

235. The transaction costs of using the market are assumed to be larger than the costs of control losses and principal-agent conflicts in the organization.

236. Thomas D. Crocker (1971), "Externalities, Property Rights and Transaction Costs: An Empirical Study", Journal of Law and Economics 14, p. 451. 
monitoring and the costs of information gathering. ${ }^{237}$ These categories also represent the cost categories suggested by Coase and Williamson.

Proposition 6: Monitoring academic production by using the market entails substantial transaction costs.

Academic administrators have great difficulty in monitoring academic production, since the productivity of scholars is not easily inferred on the basis of quantifiable variables. ${ }^{21}$ When the value of output is hard to assess, monitoring input can be an efficient way to measure productivity and to meter rewards. However, research input is often unproductive or intangible. For instance, it is hard to determine whether a scholar who is looking through the window of his office, is actually thinking very hard or simply enjoying the view. Moreover, a lot of productive scientific labor is performed outside both working hours and the location stipulated in the academic labor contract. Looking at the input side, it is often quite uncertain whether a certain research approach really is the most suitable method and whether the problem under investigation can be solved at all. It is also quite possible that a project leads to the solution of a completely different problem. For the administrator of science, monitoring input behavior reveals little information about the academic productivity of the scholars he employs.

To assess the performance of his academic staff, the academic manager is bound to evaluate the value of the output. Following assumption 2, it is also hard to gather this type of information. The evaluation of academic output would require the help of true experts, because it takes a scholar to judge the quality of another scholar's work. Hiring these experts would entail high costs. A formal assessment of the performance of a scholar would have to include the verification of his work, which would imply the duplication of large parts of the original work, and an assessment of the scientific relevance of his academic output. Following a human capital approach, the expert is likely to be paid almost as much as the scholar who is monitored, while he duplicates much of the latter's efforts. ${ }^{239}$

Transaction cost theory would argue that an organization has to be set up to economize on the high monitoring costs, which would improve the efficiency of the academic activity undertaken. Since academic productivity is costly to evaluate, the task of the science administrator is to devise a governance structure that saves on monitoring costs. The emergence of academic institutions is best understood by taking into account these transaction costs. ${ }^{200}$

237. Jürgen G. Backhaus (1989), "A Transactional Approach, to Explaining Historical Contract Structure", International Review of Law and Economics 9, pp. 223-226.

238. Cfr. assumption 2 .

239. Assuming that the ability to assess the genuine value of research output is determined by the scientific proficiency of the evaluating scholar.

240. Private or public. 
Proposition 7: The voluntary auditing procedures of the scientific community may lower the monitoring costs of academic production.

The evaluation of academic performance by the employing authorities on the basis of objective and observable variables is inherently difficult. As a result, it is hard to monitor academic production and sanction malperformance. However, the severe auditing procedures of the scientific community reduce the probability of low-quality production. ${ }^{241}$ In determining the merits of scholars, administrators only play a subordinate role. Ultimate control is not even in the hands of their university colleagues. It is exercised by the scholars in the same discipline. Although their judgement is not always right, the consensus of the scholars is fairly decisive. Scholars are not infinitely capable, but their verification procedures are among the strictest known.

"The consensus of qualified' scientists is not always right, but no better mechanism for allocating praise and blame is known. 202

Proposition 6 pointed out that the monitoring costs of academic knowledge production are quite substantial. If the scientific community functions, well in the way described by the model, the necessary control of scholars takes place in the scientific community. Following Tullock, this mechanism guarantees the production of true and accurate information. However, if scholars are capable of withdrawing themselves from the control of the scientific community, active monitoring is of vital importance for an efficient acadernic organization. Administrators can take effective measures to prevent the isolation of scholars from the scientific community. By stimulating the working of the scientific community and assuring that scholars are exposed to the scientific community, they can lower the monitoring costs of academic production. If the scholars can effectively protect themselves from having their research verified, the administration faces serious monitoring problems.

Due to the verification and use of scientific ideas, scholars also constantly evaluate other scholars in the course of their own academic activity. This knowledge, which is stored in the minds of the scholars, is a free by-product of scientific activity. But the question is how to obtain this confidential information.

Hypothesis 2: The Althoff system created a transaction-specific governance structure for academic production.

The academic system in Prussia was a typical bureaucracy, run by a public administration. The Althoff system pushed the bureaucratization process. ${ }^{203}$ The efficiency losses of bureaucracies are so considerable that transaction cost analysis explains this type of organization in terms of the more substantial costs of using the

241. Cfr, proposition 1 .

242. Gordon Tullock (1966), Organizarion of Inquiry, p. 161.

243. See observations 5,14 and 15 . 
market. ${ }^{24}$ From this, it is inferred that the specific governance structure in the Althoff era saved on the substantial monitoring costs of academic production. The Althoff system certainly tried to adapt the institutional design of the academic system to the changing nature of academic production. The growing academic system, however, entailed ever larger production and transaction costs. Althoff worked out a twofold method to economize on monitoring costs, while keeping enough pressure on academic scholars to perform well: (1) improving the functioning of the scientific community, and (2) gathering the valuable information that is stored in the community and that is indispensable to evaluate scholarly performance.

The first element has already been discussed in hypothesis 1. If the scientific community is able to play its vital role, it makes enormous academic monitoring efforts. For the second aspect, Althoff built an extensive academic information network. ${ }^{24}$ This method did require some degree of centralization because the central receiver had to span almost the entire scientific community, whose members typically work at different institutions. ${ }^{240}$ The Prussian bureaucracy used this network to monitor its academic employees. It was better equipped than the decentralized universities, that did not have a similar extensive and qualitative network. Althoff gave top scholars their own independent research institutes that were not controlled by the bureaucratic authorities. ${ }^{247}$ This underscores our rationale because the costs of monitoring researchers of true genius are low.

Hypothesis 2. states that Althoff managed to solve the information-monitoring problem, that is typical for academic management. But how did the Althoff system use the information from the scientific community to stimulate academic performance? And which institutional incentives and constraints affected scholarly behavior? Property rights analysis studies the influence of institutional structures on economic choice and behavior.

\subsection{Property Rights}

Property rights shape the institutions, in which they are specified, and determine the content of incentives and constraints, which, in turn, are the underlying determinants of performance. ${ }^{248}$ The Coase theorem says that, if property rights are established, in a world without transaction costs, they lead to efficient production outcomes. In the real world, however, transaction costs may lower or exceed the benefits of exercising and establishing these rights. Coase's point is that a more complete specification of

244. With the attenuation of property rights in bureaucracy, a principal-agent problem may arise. Then, incentives have to be created that motivate the academic agents to act in the principal's interest.

245. See observation 25 .

246. Monitoring by a central party also has considerable economies of scale.

247. See observation 16 .

248. The owner of a property right has the right to use the good he owns (usus), to appropriate returns from it (usus fructus) and to change its form or substance (abusus). 
property rights diminishes uncertainty and tends to promote an efficient allocation and use of resources. ${ }^{200}$

Which investments should be undertaken follows from the answers to the question of what system of property rights brings about the desired allocation of resources. ${ }^{250}$ The property rights structure of the institutions determines the costs and benefits that affect choice. The holder of a property right can claim the net benefits of the right and thus has an incentive not to waste resources. So, a rational economic agent is likely to take into account the true costs that affect the value of his property right. This system is likely to yield an efficient allocation of resources because individuals are motivated to take into account the costs and benefits of their actions. However, if they can shift away the responsibility for their actions due to attenuated property rights, opportunism. may lead to an inefficient use of resources. Economic performance is determined by the efficient distribution of property rights, i.e. the institutional environment in which economic agents operate.

Given the nature of academic output, ${ }^{251}$ it is not easy to establish and exercise academic property rights. Transaction cost analysis already indicated that scholars, who invest in expert knowledge and idiosyncratic human capital, have to be offered certain guarantees.

"Nonspecialization is a form of insurance when the costs and uncertainties of transacting are high. The greater the specialization [..], the more weight must be put on reliable institutions that allow individuals to engage in complex contracting with a minimum of uncertainty about the terms of the contract. "2.52

The property rights structure determines whether enough incentive is given for the optimal formation of human capital and whether guarantees are built in for the later use of human capital, which determines its value. The institutional governance structure should also protect scholars from opportunistic behavior.

\subsubsection{Externalities}

The emergence of property rights and institutions has been explained by a kind of market failure, namely externalities. The establishment of property rights has the benefit of internalizing many spill-over effects. ${ }^{253}$ Demsetz has argued that a primary function of property rights is that of guiding incentives to achieve a greater internalization of externalities. ${ }^{24}$ A lack of property rights precludes this. An

249. Ronald H. Coase (1960), The Problem of Social Cost.

250. Louis De Alessi (1969), "Implications of Property Rights for Government Investment Choices", American Economic Review 59, pp. 13-24.

251. Cfr. assumption 1 and proposition 5.

252. Douglass C. North (1990), Institutions, Institutional Change and Economic Performance, p. 34.

253. Ceteris paribus, property rights are only established, when the net benefits of the internalization are larger than the transaction costs involved.

254. Harold Demsetz (1967), "Toward a Theory of Property Rights", American Economic Review 57, pp. 347-359. 
appropriate institutional environment may internalize the external benefits of academic research, which otherwise would remain largely uncaptured by the academic producers. The emergence of such an academic framework can be understood by taking into account externalities.

"If the main allocative function of property rights is the internalization of beneficial and harmful effects, then the emergence of property rights can be understood best by their association with the emergence of new or different beneficial and harmful effects. 235

Hypothesis 3: The hierarchical Althoff system captured more free externalities of academic production than the decentralized academic system.

In the Althoff era, the German academic system was growing rapidly. To capture some of the spill-over effects, the fragmented university landscape was administered as one academic system by the Prussian bureaucracy. This policy captured the sideeffects of academic research on the work of other scholars at different institutions in Prussia, which would be lost for individual universities. Because the increase in the social value of a good tends to lead to a stronger specification of rights, it is not surprising that the Althoff system exercised its academic decision rights more strongly. ${ }^{256}$

Market failures like externalities are an important condition for government action. If the external benefits are so diffuse that they are not captured by private investors, then there is a potential role for the state. Many of the spill-over effects of academic research to the economy are free, diverse and diffuse. Following a human capital approach, academic research and training is an important determinant of economic growth. The Prussian state could eventually capture the free externalities of academic production through the growth in the tax base. ${ }^{257}$

"Basic research is a pure public good and cannot readily be marketed. Academic instruction is loaded with externalities, and this implies that the academic production process cannot readily be self-financed. This is, of course, the reason why the strategy of economic development pursued by the Prussian administrators for several centuries and culminating in Althoff's career had included the support of public universities as a core element of economic policy. ${ }^{234}$

255. ibidem, p. 350

256. See observation 15.

257. The Althoff system also used a system of state licenses to capture the economic benefits of applied academic research. Like the patent system, it allows the self-financing of applied research. In exchange for the right to mass produce the diphteria serum, the Hoechst corporation financed the research institute of Behring, whe had developed the serum. While Althoff secured the financing of the institute, the Prussian state took its cut by setting the prices for the serum.

258. Jürgen G. Backhaus (1990), Regulation and Selfregulation in the Knowledge Industry, Paper Symposium on Law and Economics, Lugano, p. 16. 


\subsubsection{Principal-Agent Relations}

The problem of monitoring sometimes causes huge transaction costs, which may hinder the full exercise of property rights. Attenuated property rights often lead to principal-agent problems. An agency relationship is a contract under which a principal engages an agent to perform some activity on his behalf and which involves the delegation of some decision-making authority to the agent. ${ }^{259}$ Being utilitymaximizers, agents do not always act in the interest of their principal, especially when there is imperfect information about their actions. The principal can limit the agency costs by monitoring the agent's behavior or by designing an incentive scheme that motivates the agent 10 act in the principal's interest. ${ }^{200}$ If the principal has limited information about the activities of his agents, he can still induce them to take into account the true costs of their behavior by delegating property rights, which motivates the agents to act efficiently. The principal should make sure, of course, that the partitioning of property rights is not unintended.

The task of the science administrator is to design an incentive scheme that motivates the academic scholar to be and stay productive without an unintended partitioning of property rights. The administrator should also find a monitoring technique that does not entail prohibitive costs. If the scientific community functions well, such a monitoring technique is available. ${ }^{261}$ The incentives for productive scholarly behavior are determined by the property rights structure which sets forth a cost-reward scheme. The agency relationship can be substantially improved by a suitable property rights system that gives the right incentives to scholars.

\subsubsection{Academic Organization}

Alchian and Demsetz claim that an organization that bundles a specific set of property rights solves the monitoring problem better than a decentralized system can do. ${ }^{262}$ This bundle of five rights constitutes the firm, which is a type of institution that deals with the monitoring-information problems more efficiently than the market. It is characterized as follows. A central party has (1) the right of control over inputs and outputs and (2) the right of control over the composition of the production team. All contracts of the firm enter into the hands of (3) one central contracting agent, who has (4) the right to claim the residual profit after all expenses have been met and (5) the prerogative to change, sell or liquidate the organization.

259. M.C. Jensen and W.H. Meckling (1976), "Theory of the Firm: Managerial Behavior, Agency Costs and Ownership Structure", Journal of Financial Economics 3, p. 308.

260. Agency costs are the sum of the monitoring costs and the residual losses of the principal plus the bonding costs of the agent.

261. See proposition 7 .

262. A. Alchian and H. Demsetz (1972), Production, Information Costs and Economic Organization. 
The combination of these property rights, that are exercised by a central agent, reduces the monitoring-information problem of team production better than a decentralized system does. The cost of monitoring the production by a central monitor, who disciplines himself because he is a residual claimant, is low relative to the cost of attempting to measure the marginal output of team members. The firm is particularly suitable for team production. ${ }^{263}$ However, there is no reason for the firm to be uniquely related or even highly correlated with team production. It may be used equally probably as a viable solution to other sources of monitoring costs. Each source of the information problem can entail specific monitoring costs, which a specific distribution of property rights may reduce. The Alchian-Demsetz model describes five property rights that determine the working of an organization. The analysis in the following chapter tries to point out how the distribution of these rights may influence academic performance.

In the traditional (German) faculty system, (1) the control over inputs and outputs is dispersed. While output control is basically left to the individual faculty member. input behavior is monitored by insisting on the observance of certain professional rules of conduct. (2) The decision right of appointing academic team members is not concentrated in the hands of one decision-maker. (3) Faculty majority voting is an often used technique here. (4) The residual claimant is the individual professor, but this status is undermined because the externalities generated by the academic production remain dispersed and unclaimed. In Germany, (5) the right to found, close or substantially change the academic production unit remained with the sovereign. As a conclusion, it is fair to say that the traditional university system does not have the property rights structure of a classical firm.

Backhaus has argued that the Althoff system can best be understood as a concerted action to run the Prussian academic system "as if" it were a classical multi-divisional firm. ${ }^{264}$ The state official Althoff was the central manager, who controlled academic inputs, monitored academic output, selected and appointed academic staff and implemented major changes in the existing system. The state became a partial residual claimant due to the growing tax base. Although the firm is not uniquely related with team production, Backhaus tries to show how Althoff's institutional innovations fulfill the original Alchian-Demsetz conditions of team production in order to fully exploit the advantages of the firm structure. However, many academic activities are highly individual efforts.

Proposition 8: The faculty system is patterned after the needs of the educational system and of individual, research activity.

263. When team production is more productive than individual production, individual contributions to the total product are not separable and individual marginal productivity of the team members is difficult to determine. Therefore, in the classical firm, individual marginal productivity is: monitored at the input side and assessed by a central coordinator. Due to the input monitoring problems, the classical firm structure can, not, simply be adopted for the organization of academic production.

264. See: Jürgen G. Backhaus (1989c), "The University as an Economic Institution", Working Paper 89.017, University of Limburg. 29 pp. 
Academic research is very often carried out by scholars who work by themselves. The traditional German university system was exactly patterned after this type of research. Faculty members are combined in faculties for teaching purposes and work independently from each other. Their productivity is not dependent on the productivity of a colleague, who may teach completely different subjects, but on the informal cooperation with other scholars in the scientific community who work at different locations. Although there is little team production in the faculty system in the Alchian-Demsetz sense, this need not imply that the firm structure is inadequate for academic production. ${ }^{2 \mathrm{~s}}$

Some academic activities can be carried out by formal team production. By its very nature, multi-disciplinary research is a candidate. Data collection is also susceptible to team production. Research can be done by the formal cooperation of many scientists working on essentially the same research program. In these cases, the productivity of one scholar clearly depends on the work of the other. Formal team production is a feasible solution for some academic activities. However, the truely productive moment of scientific discovery remains in many cases the outcome of the mental activity and ingenuity of the individual members. ${ }^{256}$ This does not preclude that research is a highly cooperative activity. Most of the interaction between scholars, however, takes place in the informal scientific community. ${ }^{267}$ In team production, the interaction with academic colleagues may play a similar role.

Proposition 9: Research institutes are patterned after the needs of academic team production.

When the specific scientific requirements of concerted research programs require the formal cooperation of many scholars, specific institutional responses are needed, because the traditional faculty system is not patterned after this type of research. Specific research institutes may accomodate team production. This system has the advantage compared with the traditional faculty system e.g. of having more strictly defined measures in terms of the research program by which to monitor the academic performance of its members. However, it is not certain whether the team auditing procedures lead to a better performance than those of the scientific community. If the team has a monopoly and is capable of withdrawing itself from the control of the scientific community, the quality of the output is likely to diminish. This reinforces our assertion that the informal aspects of scientific team production remain important, which leads to the following proposition.

Proposition 10: The ultimate control of the academic output of an institute remains with the scientific community although team production clearly offers internal monitoring advantages.

265. As mentioned earlier, the firm is not uniquely related to team production.

266. It is often argued that medical progress is related to the systematical treatment of large numbers of patients, requiring a team of physicians. However, a new medical procedure is often discovered (produced) by one physician, who applied it on just one patient.

267. See assumption 3 . 
Hypothesis 4: Althoff's independent research institutes and seminars stimulated formal academic team production.

In the Althoff system, large research projects were organized in a new institutional form, namely seminars and independent research institutes. ${ }^{20}$ Each independent research institutes was directed by an outstanding scholar, who laid out the program and coordinated the activities of his collaborators. Since the scientific reputation and residual income of the director depended on the performance of his institute, he had a clear incentive to monitor his collaborators. In the seminars, which were also conducted by prominent scholars, young scientists were educated to do research in a formally interactive way. They worked together on a specific research program. For example, the historical-economic research program laid out by Gustav Schmoller could only be carried out as a common venture. The same was true for the historians and archeologists. With the creation of large laboratories, natural scientists, who had been educated in different disciplines, also began an intense formal cooperation. Medical progress in the Althoff era was also related to the construction of large clinics, in which large numbers of patients with similar conditions could be treated with a new medical procedure or drug.

Proposition 11: The evaluation of academic output as an instrument of control should be the rule, evaluation of input behavior the exception.

\section{Backhaus, has argued that.}

"Most scholarly work is of a kind such that its value can be ascertained only by repetition. This is an extremely time-consuming approach for the measurement of quality, and consequently academic professions tend to develop a code of conduct which will under normal circumstances ascertain proper and reliable results. I..I Monitoring input is the only way to assess performance because marginal productivity can only be assessed per team, not per individual. Hence " input behavior is observed in order to assess output performance. ${ }^{20}$

However, most verification takes place as a free by-product of scientific activity. Scholars may sometimes engage in the repetitive verification of the work of others, but most of the time they evaluate scholarly output in the course of their own research activities. Professional ethics, the strength of which is not so easily observable, play a secondary role in controlling academic performance. Many scientific discoveries are even made by accident or non-conformistic behavior. The indoctrination of professional standards is not the main instrument of control. Instead, the disciplinary procedures of the scientific community do modify scholarly behavior to cautiously produce reliable research results.

The evaluation of academic productivity by monitoring, output is more difficult, however, in the case of team production and young inexperienced scholars. In spite of the problems with monitoring input behavior, the marginal productivity of scholars 
who are engaged in team production can also be assessed at the input side. The team's monitor can observe whether a scholar adheres to some code of academic conduct in the team or whether he has obtained intermediate research goals. Monitoring input performance by a peer is also practically the only way to assess the performance of a junior scholar, because there is little output yet. This does not imply that young scientists should not be exposed to the scientific community. With few exceptions, academic control takes place in the scientific community. Following proposition 6, reciprocal monitoring among scholars is a rational solution, because the costs of specialized management of academic input are rather substantial. In our basic model of scholarly behavior, there is no active role for a central monitor. Yet, a central manager can actively stimulate the system of control by trying to keep the scientific community open, thereby introducing more competitive pressure. ${ }^{20}$

Property rights shape the institutions, in which they are specified, and determine the content of incentives and constraints, which, in turn, are the underlying determinants of performance. Following Alchian and Demsetz, the following property rights are studied in more detail: ${ }^{271}$ (1) the right to appoint the members of a faculty or academic institute, who determine its performance; (2) the right to monitor academic performance, reward productive and sanction unproductive scholarly behavior; (3) residual claimancy, if the academic residual can be captured; (4) the right to change (part of) the structures of the academic system, i.e. the agreed or innovative reallocation of property rights; (5) the existence of a central party common to all inputs, which creates a bureaucracy. It has been pointed out that the classical firm can deal with different information-monitoring problems, not only those associated with team production. Jensen and Meckling have confirmed that the emphasis placed on joint input is too narrow. The problem of agency costs exists for all contractual relations, independent of team production. ${ }^{272}$

Scholars respond and adjust their behavior to the institutional environment in which they work. Different organizational designs provide different incentives to scholars, which affect academic performance. Since the Althoff system implemented several institutional innovations, our analysis tries to show how a different distribution of property rights influences academic productivity. To answer the initial question of how the organization and change of the Prussian academic system affected academic performance, the institutional differences between the traditional university system and the new academic system are studied in terms of property rights.

270. Hypothesis 1 pointed out that Althoff appointed outsiders in homogeneous faculty structures, emancipated the technical colleges and set up international professorial exchanges in order to keep the academic community open. Building on the traditional structures, Althoff introduced new forms of direct regulation, aimed at the dissemination of research results and the deregulation of discriminating procedures. This indicates that an administrator of science can take corrective action toward scientific community failures.

271. See chapters 7 and 8 .

272. M.C. Jensen and W.H. Meckling (1976), Theory of the Firm, p. 310. 


\section{Academic Property Rights and Scientific Production}

7.1. Academic Appointments

7.1.1. Cooptation Right

Proposition 12: It is rational for faculty to be ignorant about the research performance of present and potential faculty members.

Hypothesis 5: Althoff improved the selection of academic scholars in Prussia by processing information generated by a network in the scientific community.

\subsubsection{Screening of Candidates}

Prop. 13: The quality of the screening and subsequent signaling variables in selection procedures, determines academic performance.

Hyp. 6: The Althoff system stimulated academic performance not only by appointing productive scholars, but also by the incentive value of its screening method.

7.1.3. Residual Claimancy

Prop. 14: The right to claim the residual gives an important incentive to the holder of the right to carefully monitor academic scholars and evaluate candidates.

Prop. 15: The academic residual can take the form of increased academic reputation or of increased revenues from an increased tax base.

Hyp. 7: The Althoff system improved the quality of academic appointments by having the residual claimant make the final decision. 


\subsection{Academic Compensation}

\subsubsection{Implicit Contracts}

Prop. 16: Academic compensation, which is not likely to reflect the marginal productivity of a scholar, functions as an incentive for academic performance.

Hyp, 8: The Althoff system is likely to have set an efficient level of compensation, since the residual claimant determined academic rewards.

\subsubsection{Academic Salaries}

Hyp. 9: In accordance with human capital and implicit contract theory, the Althoff system paid low starting salaries for young scholars and huge wages for top scholars.

\subsubsection{Research Facilities and Prizes}

Prop. 17: Research facilities and scientific prizes are likely to stimulate the performance of the pure curiosity scholars.

Prop. 18: Salaries and non-specified monetary prizes are likely to stimulate the performance of the induced curiosity scholars.

Prop. 19: Non-specified awards may provide a stimulus for basic research, much as the patent system works for applied research.

7.2.4. Academic Tenure

Prop. 20: Tenure is likely to lower academic performance, unless the scientific community continues to perform its auditing, and disciplinary role.

Prop. 21: Academic tenure may entail substantial rent-seeking costs as well as benefits.

Prop. 22: Tenure protects the idiosyncratic investments of the tenured. scholar.

Hyp. 10: The Althoff system reduced the disadvantages of academic tenure.

\subsubsection{Teaching and Research}

Prop. 23: The salary system is better attuned to the dual academic production of teaching and research than is the (strict) fee system.

Prop. 24: Teaching and research can be separated as long as academic output is freely disseminated. 


\section{Academic Property Rights and Scientific Production}

Did the Althoff system allocate resources efficiently? How did it select and appoint academic scholars? Was there a consistent compensation package that motivated Prussian scholars to perform well? The first property right is the right to control input and output. In the academic system, this means monitoring scholarly activities and assessing the productivity of the academic scholars. It also implies the rewarding of productive behavior and the sanctioning of malperformance. The second property right is the right to hire (and fire) employees. This task consists of selecting and appointing scholars. Let us look at this responsibility first.

\subsection{Academic Appointments}

\subsubsection{Cooptation Right}

When faculty decide whom they want as a new member, they exercise their so-called cooptation right. This cooptation right of faculties, which is still widespread, is viewed as an important safeguard of academic freedom. Although the employing authorities may officially appoint the new academic scholars, they typically ask faculty for an opinion concerning the academic credentials of candidates and leave the outcome of the decision to the university professors. This procedure was also customary in Prussia. The university that had a vacant chair to fill was asked by the Ministry of Culture to suggest a candidate. Although the appointment was made by the sovereign $n_{n}$ the faculty proposal was approved most of time.

Proposition 12: It is rational for faculty to be ignorant about the research performance of present and potential faculty members.

Most of the vital information about the productivity of a scholar and the value of his research output is known to the scientific community in his field. ${ }^{273}$ The members of this community typically work at different institutions at different locations, dispersed for teaching purposes. In turn, the traditional faculty is composed of a large number of scholars, who are active in different disciplines. ${ }^{274}$ Indeed, the university community is not identical to the scientific community of scholars in a certain field. Only a few members of the faculty are likely to work in more or less the same field as the candidate, while the majority of faculty members is more or less ignorant about 
his qualifications. ${ }^{275}$ Because their marginal productivity is not substantially affected by appointments in other disciplines, faculty members invest little time and effort in evaluating a candidate and remain rationally ignorant since it is already hard to keep up in their own disciplines.

The selection of candidates is, therefore, often delegated to a small committee with members who work more or less in the same field as the candidate. These faculty members may have a direct incentive not to appoint the best candidate, if their position and share of the budget is to be negatively affected by adding dynamic and new members. On the other hand, a less able candidate might inflict damage to the reputation of the faculty, which reduces the ability to raise funds. However, faculty reputation is a public good. The benefits of having the best candidate, who might increase the reputation and the total budget of the faculty, is shared by many, while the cost is borne by the individual committee members who have to invest time and effort in assessing the performance of a candidate in a discipline they are not so familiar with. This creates a free-ride incentive for these committee members to remain largely ignorant about the qualifications of the candidate.

If most faculty members remain rationally ignorant about the academic credentials of a candidate, other criteria become more important for appointment decisions. It seems reasonable to argue that this will not lead to the consistent appointment of the most suitable candidates. The cooptation right, exercised by small preselecting committees and subsequent faculty majority voting, tends to lead to the preference of better known over better qualified candidates. Indeed, the cooptation right has been used as a discriminatory instrument aimed at professional homogeneity. In Prussia, Protestant faculties discriminated against Catholic, Jewish, atheist and Social Democratic scholars for no other reason than their convictions. This practice was partially overcome by stimulating scientific competition and by keeping the academic community open, which forced faculties to take the best candidate irrespective of race, sex or religion. ${ }^{276}$

A fundamental solution lies in the design of a system that gathers reliable information about the academic performance of scholars, which is stored in the scientific community. Such a system would have to create incentives for the vital information to be released and to be transmitted without distortion. The valuable information would have to be processed appropriately as well.

Hypothesis 5: Althoff improved the selection of academic scholars in Prussia by processing information generated by a network in the scientific community.

Althoff had observed that the cooptation method had failed to bring about the desired results in Germany. ${ }^{2 n}$ But in order to make better appointment decisions himself,

\footnotetext{
275. Since only a few faculty members are likely to work in more or less the same field as their present colleagues, the majority is quite ignorant about their qualifications as well.

276. Cfr. hypothesis 1 .

277. See observation 27.
} 
he needed accurate and specialized information about the academic performance of candidates. This information is typically stored in the scientific community. So, he confidentially consulted other scholars. This direct monitoring of output performance is what made Althoff legendary. Because the scope of science was so large, it was necessary to maintain a whole network of confidential agents. It was his accomplishment to have established this network of experts in virtually every relevant discipline. This allowed him to gain the advice of different experts in the same discipline. ${ }^{2 m}$ The network, which embraced the scientific community, generated the information that was needed in order to substantially improve the selection of scholars in comparison with the faculty cooptation system. Following proposition 6 , it also lowered the transaction costs in the Prussian academic system.

\subsubsection{Selection of Candidates}

Proposition 13: The quality of the screening and subsequent signaling variables in selection procedures determines academic performance.

Spence and Johnson have argued that the main function of an academic education is not to increase the skills and knowledge of students, but to provide a screen that determines which students are able to obtain important positions. ${ }^{279}$ Passing the screen has important signaling value in the labor market. Wolpin tested the screening hypothesis, but found evidence in support of the standard human capital theory. ${ }^{2 \mathrm{so}}$ However, the real issue concerns not the mere existence of one or the other effect, but the extent to which education performs each of these roles. ${ }^{2 n 1}$ Garner has applied the model to the case of scholars being screened for initial employment and subsequent promotion. He argues that the common practice of screening on the basis of quantity of publications

"may bias research decisions toward orthodox, low-risk projects, denying science the bold hypotheses and vigorous competition necessary for significant advance. $2 \mathrm{n}$

While publication is an essential scholarly activity, problems arise when objective variables are considered to be the sole signal of professional ability. Screening on the basis of the number of publications induces scholars to pursue conventional, instead of innovative, research. Indeed, screening practices sometimes help to explain the patterns of scientific development. The methods ultimately determine signaling pressures which affect the nature of academic research and influence the choices of

278. See observations 25 and 26 .

279. Michael Spence, (1973), "Job Market Signaling", Quarterly Journal of Economics 87, pp. 355374, and Harry G. Johnson (1973), "The University and Social Welfare", Minerva 11, no. I. pp. $30-52$.

280. Kenneth I. Wolpin (1977), "Education and Screening", American Economic Review 67, no. 5, pp. 949-958.

281. ibidem, p. 957.

282. Alan C. Garner (1979), "Academic Publication, Market Signaling and Scientific Research Decisions", Economic Inquiry 17, p. 575. 
scholars. This need not be detrimental to scientific development per se. It just depends on the type of screening variables the employing authority uses.

Dependence upon a quantitative variable such as the number of publications might lead to a proliferation of minimum publishable articles that have a minimal added value, while citation counts induce the creation of citation cartels. Personnel policy determines academic performance to the extent that scholarly productivity is taken into account and to the extent that there exist signaling incentives which favor either established or innovative research strategies. To improve academic performance, remedies may come from the screening methods used by the employing authorities.

Hypothesis 6: The Althoff system stimulated academic performance not only by appointing productive scholars, but also by the incentive value of its screening method.

Following hypothesis 5, Althoff managed to select productive scholars by using a network, which he had carefully built in the scientific community. The combination of propositions 1 and 13 leads to the conclusion that the selection of suitable candidates on the basis of information from the scientific community also improved academic performance by using the high standards of the scientific community as signaling pressure. The informal scientific community played a formal role in the performance-based Althoff system.

Maintaining the quality of the network was, therefore, of the utmost importance for Althoff. The subjective information on the performance of a candidate-scholar had to be as unbiased as possible. ${ }^{283}$ The independent information of numerous top scholars. was evaluated on accuracy, speed of response and unanimity. ${ }^{284}$ Although they may not have been under great pressure to give correct information under the shield of the confidential procedure, their membership depended on the quality of their information. Biased judgements about scholarly performance could easily be detected by comparison with the other members that were consulted. However, there was also an important incentive for these strategic network members to keep sending accurate information. Abuse of the trust, built between Althoff and them, could have serious career consequences and exclusion from the network.

283. For a young scholar, most of the indicators of scientific performance are not yet available. Therefore, an evaluation is made on the basis of a number of input: variables. To make appraisals by peers as accurate as possible, there should go some credit for the training and recommendation of new scholars to their academic superior, while some of the blame for inaccurate appraisals should reflect on this senior scholar as well.

284. The members of the confidential academic network, who belonged to different institutes, were often asked for their opinion about a scholar. Althoff was more confident in appointing the right candidate when they unanimously proposed one specific scholar. He would be suspicious if faculty proposed another. 
Katz found out that some administrators of science do try to assess the research ability and national reputation of scholars, in addition to their publication record. ${ }^{20 s}$ Teaching ability and public service to the university had less influence on their personnel decisions. The administrators revealed that they could assess the quality of a publication by noting whether or not an article was rated good by experts and was published in a quality journal, and whether or not a book received good reviews. As our analysis pointed out, they looked for judgements by experts from the scientific community. But the outcome in this case depends on the quality of the formal reviewing and editorial process, whereas most evaluation remains unpublished and stored in the informal scientific community. Sound decision-making is dependent on the ability of the administrator to understand, interpret and critically evaluate the scientific comments from other scholars, whereas Althoff asked for direct statements on the position of a scholar in the scientific community. Katz did not point out either whether these administrators could overrule faculty decisions if they had another opinion about the quality of a candidate.

\subsubsection{Residual Claimancy}

Proposition 14: The right to claim the residual gives an important incentive to the holder of the right to carefully monitor academic scholars and evaluate candidates.

This is the basic argument of the Alchian-Demsetz scheme. The agent who can claim the residual has an incentive to monitor (in)efficient behavior and evaluate new employees. Because he is more likely to invest in an appropriate evaluation technique, it follows that he is also granted the right to make appointments in spite of the problems associated with the evaluation of performance.

Proposition 15: The academic residual can take the form of increased academic reputation or of increased revenues from an increased tax base.

Following property rights theory, the information-monitoring problem can be reduced, if the monitor is the residual claimant. The residual has a special form in the case of public goods and externalities. When consumption is free or not excludable, no proceeds are generated that can create a residual. In that case, residual claimancy is not fully exercised. Academic production may not produce a residual that can be easily claimed. ${ }^{286}$ Even if there is a residual, the university is often a nonprofit organization, which cannot distribute the residual among owners. ${ }^{207}$ It is held in reserve or used for the future expenditures of the organization.

285. David A. Katz (1973), "Faculty Salaries, Promotions and Productivity at a Large University", American Economic Review 63, no. 3, pp. 469-477.

286. The patent system allows the capture of some residual gains from applied research. It assigns a private property right to knowledge. The focus of our analysis, however, is on academic output, which often takes the form of a public good, loaded' with free externalities.

287. A.G. Holtmann (1988), "Theories of Non-Profit Institutions", Journal of Economic Surveys 2. no. 1, pp. 29-45. 
In a sense, however, scholars can be said to be the residual claimants of their own academic efforts. The residual may take the form of an increase of their reputation in the scientific community. When academic output is put to productive use, another residual claimant appears in the form of the tax authority. ${ }^{2 s}$ Assuming that academic teaching and research stimulate economic progress, the state has a larger tax base upon which to levy taxes. For basic research that is not yet put into practical use, the scholar can be viewed as the sole residual claimant. The residual of applied research can also be the patent-holder or the tax state. As far as teaching is concerned, a lecturer may exclude some students and charge lecture fees.

When the cost of excluding nonpurchasers is great, private production of public goods does not seem practical. If no consumer can be excluded, all may tend to underreveal their true marginal willingness to pay for the good. It may be possible, however, to tie in the consumption of a second product with the consumption of the public good. Private incentives may very well exist for the production of the tied-in good. ${ }^{205}$ The tie-in mechanism does not automatically lead to the efficient private production of some public goods, but may create a residual for the private sponsor.

Althoff used some tie-ins. Special favors or circumstances were used to secure resources from private sponsors. Every conceivable source could be tapped in exchange for special grants, promotions, ennoblement, orders and other distinctions. ${ }^{290}$ Sometimes, sponsors were attributed property rights. In the Göttingen Association and the Kaiser-Wilhelm-Gesellschaft, private sponsors and the state were represented in a board that monitored the rational use of resources in the academic institute. State representatives protected the research program against commercial pressures. The sponsors exercised a sort of input control, while the output control was left to the scholars and the scientific community. Providing and securing financial resources is an important task of the academic administrator. The long-term approach of certain research projects requires a stable financial basis for academic production. The multi-source funding approach successfully integrated the private sector and made the system less vulnerable to political interference, while strengthening its financial base.

Hypothesis 7: The Althoff system improved the quality of academic appointments by having the residual claimant make the final decision.

In the Althoff system, appointment procedures differed between the traditional universities and the independent research institutes. In spite of the cooptation right, faculty members were selected and appointed by the central Prussian administration, while institute directors could freely choose institute members. Since the institute director was entitled to the financial residual and owed his reputation to the performance of his institute, he had a clear incentive to monitor his collaborators and

288. Or the patent-holder.

289. Harold Demsetz (1970), "The Private Production of Public Goods", Journal of Law and Economics 13, no. 2, pp. 293-306.

290. See observations 32 and 33. 
to select and appoint the best candidates. Since the director also defined the research program, he could maintain specific criteria for output control. If he used specific research procedures, performance could be monitored by observing input behavior as well, especially in team production. Although the central monitoring status has some clear advantages, it is the scientific community which, in the end, monitors scholarly performance by verification and dissemination without even knowing the internal monitoring procedures of the academic institution. A bad personnel policy, resulting in poor performance, ultimately reflects on the institute director. Therefore, Althoff decided to delegate the appointment responsibilities to the institute directors.

The appointments of faculty members, however, were handled by the central administration of the Prussian state, which could claim a twofold residual. The relationship between the academic productivity and the fertility of the tax base was never neglected by the Prussian administration. ${ }^{291}$ Therefore, the Althoff system put an emphasis on research that was immediately conducive to technical and social progress. ${ }^{2 n}$ The Prussian state could not only claim a financial residual, resulting from the growth in the tax base, but was also motivated by the international reputation of German science and scholarship itself. The Althoff system used the scientific community to protect the reputation of the German academic system. By consulting the leading experts in the profession, Althoff tried to preserve high standards at Prussian academic institutes. This meant that, on occasion, another candidate was appointed than faculty would have wanted.

The reputation of the faculty is a public good. Faculty members are likely to take a free-ride and remain largely ignorant about the credentials of a candidate because appointments in other disciplines do not cause a substantial increase in their individual reputation. ${ }^{293}$ The reputation of an entire discipline is also a valuable collective good. Indeed, low-quality production may impair the future of a whole profession. Scholars have an interest in protecting the reputation of their discipline, which directly influences their own. Since, they monitor the activity of other scholars simply in the course of their own activities, the cost of assessing and reporting low-quality output is quite low, which gives the scientific community a clear advantage over the university community in these matters. ${ }^{294}$

Lecture fees created a strong incentive for the individual teacher to monitor his own teaching performance. ${ }^{295}$ Althoff decided to cap these fees partially to strengthen the cooperative aspect of academic teaching. The receipts were used for discretionary purposes. This had the effect of containing competition among professors for students

291. See hypothesis 3.

292. Along with a principle of academic freedom, Althoff supported e.g. the chair socialists, who formulated practical recommendations for economic and social policy. $\mathrm{He}$ also stimulated medical progress related to public health issues. The academic emancipation of the technical colleges was another measure to stimulate the productive use of academic output.

293. See also proposition 12 .

294. Cfr. proposition 1.

295. See proposition 23 
and strengthening the institute system by attracting leading scholars with salary supplements and supporting the non-salaried faculty members.

The appointment of good scholars was a precondition for the scientific performance of Prussia. However, it is only one aspect of a successful science policy, because

"efficient production with heteregeneous resources is a result not only of having better resources, but in knowing more accurately the relative productive performances of those resources. Poorer resources can be paid less in accord with their inferiority; greater accuracy of knowledge of the potential and actual productive actions of inputs rather than having high productivity resources makes a firm (or an assignment of inputs) profitable.

Therefore, the compensation policy requires a close look as well. Althoff introduced some major innovations in this area.

\subsection{Academic Compensation}

The economic theory of labor markets suggests that workers receive their marginal revenue product. However, compensation in real-world labor markets often does not correspond with the theoretical wage. In practice, the variation in productivity of scholars does not coincide with their wages. Academic salaries are often based on a fixed wage scheme. The implicit contract theory reconsiders the function of compensation to explain this forementioned observation. ${ }^{297}$

\subsubsection{Implicit Contracts}

A contract is a voluntary agreement that resolves the distribution of uncertainty as to the value of labor productivity. When wage payments are negotiated beforehand and laid down in a contract, they reflect both labor productivity as well implicit payments or indemnities of insurance. The implicit contract theory argues that, over their lifetime, workers are paid the value of their marginal product, although in any single period the worker may be paid more or less. The idea behind this is that workers are risk-averse and that therefore the organization provides an earnings insurance by paying the worker more than productivity merits during periods of low worker productivity and less during periods of high productivity. The implicit insurance is meant to promote socially beneficial activities by separating expected benefits from fear of risk.

296. A. Alchian and H. Demsetz (1972), Production. Information Costs and Economic Organization, p. 794.

297. For a survey of the implicit contract theory, see: Sherwin Rosen (1985), "Implicit Contracts: A Survey" Journal of Economic Literature 23. no. 3, pp. 1144-1175; or: Donald O. Parsons (1986), "The Employment Relationship: Job Attachment, Work Effort and the Nature of Contracts", in: O. Aschenfelter and R. Layard (eds.). Handbook of Labor Economics, vol. 2, Elsevier, Amsterdam, pp. 789-848. 
Implicit contracts play a major role in the academic system, because the value of academic output is extremely uncertain and the risks of innovative research are rather high. When scholars receive monetary compensation, their wages often do not reflect their actual academic productivity. Moreover, their theoretical wage level is hard to determine. Following assumption 2, precise measures of scholarly productivity are not easily available since academic output is not readily marketable. Following proposition 6, it is also extremely costly to measure individual differences in academic productivity well enough for these differences to be reflected in compensation. Although scholarly productivity within the contract period is uncertain, information on the performance of a scholar is generated by the scientific community. The contract thus has to incorporate some rules for the adjustement of compensation. $^{29 n}$ While standard economic models would argue that scholars are paid their marginal revenue product by cost-minimizing organizations that buy their services in competitive labor markets, academic compensation is different than would be warranted for productivity reasons alone.

Proposition 16: Academic compensation, which is not likely to reflect the marginal productivity of a scholar, functions as an incentive for academic performance.

Under competitive conditions, workers are paid the value of their marginal products. The economic and transactional properties of academic output make it hard to determine appropriate academic compensation. ${ }^{299}$ However, the administrator may take account of the simple fact that maintaining incentives and selecting the best candidates has great value for the performance of the academic system. Payments to chairholders and institute directors have indirect effects of increasing productivity down the hierarchy. Although the large salaries of top scholars may not correspond with their current marginal productivity, they provide incentives for all individuals in the academic community, who work to get one of the top positions.

If marginal revenue product is hard to determine, the relationship between compensation and productivity lies in the incentive value of the compensation schemes. Lazear and Rosen have modelled this in a rank order tournament. ${ }^{300}$ They argue that top bureaucrats do not necessarily earn more because they are more productive, but because the incentive payment structure makes them more productive over their entire working lives. The top position is a reward for the winner of a rank order tournament. This requires only an assessment of the relative output levels. However, a threshold is necessary to guarantee the overall quality of the competition.

The scientific community plays an essential role in promoting competition among scholars, while it also succeeds in preserving cooperation. The chairholder or institute

298. Seniority and level of education are often used as performance proxies to determine rewards.

299. In spite of implicit contract theory, it is highly unlikely that academic scholars are paid the value of their marginal product over their life-time. Nevertheless, the wage-incentive idea from implicit contract theory is maintained in this analysis.

300. Edward P. Lazear and Sherwin Rosen (1981), "Rank-Order Tournaments as Optimum Labor Contracts", Journal of Political Economy 89, no. 5, pp. 841-846. 
director can be viewed as the winner of a scientific contest. Such positions. serve to induce the other scholars to perform well in more junior positions. The challenge to beat a standard has the same incentive effect as attempting to beat a competitor. Scholars could be compensated on the basis of the value of their academic output or on the basis of their position in the scientific community. Both methods induce them to work hard. For the academic administrator, it may be less costly to observe relative positions than to measure the value of each scholar's output.

Rosen has pointed out the importance of top salaries and top-ranking prizes for top bureaucrats. They keep them performing, independent of past achievements. A contest may be disadvantageous to timid individuals, who undervalue their performance. Therefore, private incentives may exist to invest in signals that mislead opponents. $^{.01}$ Spence conjectured that these signaling costs are negatively correlated with productivity. ${ }^{302}$ This again emphasizes the importance of screening and signaling variables in academia. In the academic system, rewards may take many forms: professorships, attractive salaries, sabbatical leaves, tenure, scientific prizes and research facilities.

The Althoff system used several compensation forms for academic performance. A professorship at a Prussian university was the final goal of most scholars ${ }^{303}$ Faculty members were paid a fixed salary with the exception of the private lecturers. ${ }^{304}$ Wage increases were basically determined by the seniority principle. However, Althoff could and did pay higher wages to reward outstanding performance or to attract international top scholars. The income of most faculty members was supplemented by lecture fees, which constituted an important part of their total earnings. Althoff succeeded in capturing some rents by taxing part of the excessive lecture fees, which he used to attract top scholars and to improve the financial situation of the unpaid faculty members. Top scholars could also count on excellent research facilities. In the Wilhelminian era, marks of honor also played an important role. The Althoff system had a broad array of compensation instruments which were used to reward academic performance.

Hypothesis 8: The Althoff system is likely to have set an efficient level of compensation, since the residual claimant determined academic rewards.

The residual claimant has an incentive to determine an appropriate compensation level. If compensation is put too low, he may not find enough workers or only workers with poor skills. In the opposite case, he suffers residual losses. The Prussian state via Althoff determined the compensation level of professors and institute

301. Sherwin Rosen (1986), "Prizes and Incentives in Elimination Tournaments", American Economic Review 76, pp. 701-715.

302. Michael Spence (1973), Job Marker Signaling, p. 358.

303. Chairs often remained vacant for long periods, which indicates that Althoff maintained a threshold of minimal academic standards.

304. The private lecturers took the risk of having to finance their research themselves. A potential pay-off, e.g. in the form of a professorship, came only as a reward for successfully completed research. 
directors, while they, in turn, determined the compensation of their research collaborators.

\subsubsection{Academic Salaries}

Following the standard proposition that workers should receive earnings equal to the value of their marginal product, some economists have studied the salaries of university professors. When salary functions are determined, they implicitly assume they have precise measures of scholarly productivity. On these premises, Tuckman, Gapinski and Hagemann e.g. have argued that the wage level of faculty members is determined by their research skills. ${ }^{305}$ Professional reputation has also been recognized as an important determinant of salary differences among scholars. ${ }^{306}$

Gary Becker has argued that investment in human knowledge is an important determinant of economic growth, just like investment in physical capital ${ }^{907}$ In turn, education and training are important factors that explain the differences in earnings among individuals and at different points in the life-cycle of the same person. Human capital theory argues that the accumulation of knowledge usually has a positive effect on earnings. With respect to academic scholars, however, most human capital is acquired by self-education. This makes it difficult to draw their human capital-earnings profile. Moreover, as human-capital theorists point out themselves, it is not the accumulation of knowledge, but rather the creative use of it, that determines the pay-off of human capital formation. While Becker assumes that human capital is primarily embodied in individuals, Aoki argues that human capital may be accumulated by means of a collective learning process as well. ${ }^{309}$ For the Althoff system, this underscores both the role of the team work in the independent research institutes and the interactive learning method in the seminars.

Freeman has applied the implicit contract model to the case of research scientists. ${ }^{310}$ The lack of information about salaries leads to strategies by administrators to exaggerate actual wage differences in order to reduce utility resulting from low productivity. Top scholars are in effect paid huge salaries, which are meant to induce

305. Howard P. Tuckman, James H. Gapinski and Robert P. Hagemann (1977), "Faculty Skills and the Salary Structure in Academe: A Market Perspective", American Economic Review 67. pp. 692-702.

306. Daniel S. Hamermesh, George E. Johnson and Burton A. Weisbrod (1982), "Scholarship, Citations and Salaries: Economic Rewards in Economics", Southern Economic Journal 49, no. 2, pp. $472-481$.

307. Gary S. Becker (1964), Human Capital, National Bureau of Economic Research, New York.

308. See also: Jacob Mincer (1974), Schooling. Experience and Earnings, National Bureau for Economic Research, New York. For a recent survey of the economics of education, based on human capital theory: George Psacharopoulos, ed. (1987), Economics of Education: Research and Srudies, Pergamon Press, Oxford:

309. Mashiko Aoki (1984), The Co-operative Game Theory of the Firm, Clarendon Press, New York/Oxford.

310. Smith Freeman (1977), "Wage Trends as Performance Displays Productive Potential: A Model and Application of Academic Early Retirement, Bell Journal of Economics 8, pp. 419-443. 
other scholars to reduce inefficient behavior. Freeman concludes that junior scholars must accept reduced initial earnings in the prospect of the assurance of stable future incomes because of the uncertainty of their production. Moreover, jobs that have a relatively low training component, must pay relatively high salaries, because the individuals, who accept these positions, are sacrificing high future income. Because research skills require a longer period to develop than teaching skills do, researchers accept lower starting salaries. ${ }^{31}$

Hypothesis 9: In accordance with human capital and implicit contract theory, the Althoff system paid low starting salaries for young scholars and huge wages for top scholars.

Professors at Prussian universities earned a fixed salary as members of the civil service. But Althoff made considerable efforts to attract top scholars by offering them higher salaries. ${ }^{312}$ Following proposition 16, this created an incentive for junior scientists. Young Prussian scholars often started their career as private lecturers and received no income other than their lecture fees. They also lived from private wealth or were supported by their spouses. The compensation of the unsalaried lecturers was contingent upon real, not expected academic output. So, they were able to earn a living with teaching, which required skills that were acquired over a shorter period.

Income differences may be necessary to recruit and keep enough incentive for qualified scholars in disciplines where demand is increasing rapidly. ${ }^{313}$ However, equity considerations may interfere with efficiency standards. Income discrimination on the basis of popularity is bound to clash with the principle of academic solidarity and equality. Therefore, Althoff put a lot of the applied and technical research activities into institutes that were independent of the traditional university system. Business schools were financed by private sponsors and the Ministry of Commerce. This made it possible to pay higher wages in these disciplines without putting pressure on the rest of academic salaries. The lecture fee system also created an income difference in favor of those disciplines that were more in demand.

\subsubsection{Research Facilities and Prizes}

Incentives are designed to induce or restrain some activity. Performance can be improved by designing better incentives. An effective academic compensation structure has to set incentives tailored to the motivations of scholars. In this way, the academic administrator can resolve part of the agency problem. Scholars who are motivated by pure curiosity, do not have to be monitored as closely , because they are

311. George E. Johnson and Frank P. Stafford (1974), "Lifetime Earnings in a Professional Labor Market: Academic Economists", Journal of Political Economy 82, no. 3, pp. 549-569.

312. See observation 21.

313. A.G. Holtmann and Alan E. Bayer (1970), "Determinants of Professional' Income Among Recent Recipients of Natural Science Doctorates", Journal of Business 43, no. 4, pp. 410-418. 
self-motivated to perform well. Providing compensation forms that particularly attract these scholars, may therefore be one way to economize on monitoring costs.

Proposition 17: Research facilities and scientific prizes are likely to stimulate the performance of the pure curiosity scholars.

Scholars who do research simply as a living, have an induced curiosity and have to be motivated to devote their attention to research. They are more easily distracted by other goals. This creates an agency problem, which is aggravated by severe monitoring problems and attenuated property rights. Therefore, the administrator may want to attract pure curiosity scholars, who are self-motivated to do research. Such a personnel strategy cannot be implemented simply by asking the candidates to reveal their true motivations. However, compensation-incentives like research facilities and prestigious scientific prizes are more likely to attract those who are genuinely interested and personally devoted to solving scientific problems than the induced curiosity scholars.

Transaction cost analysis has suggested that the monitoring of scholars may be expensive. It seems reasonable to argue that the institute directors are truly devoted to the research program, which they have laid out themselves, i.e. they are pure curiosity researchers. This would imply that they do not have to be monitored that closely because they are self-motivated to perform well. If the institute director is an induced curiosity scholar, the financial residual forms an important incentive for productive behavior. In both cases, the reputation of the top scholar and institute director makes it very likely that his academic output is more often read, used and tested by the scientific community than the products of less-reputed scholars. This also lowers monitoring costs for the administrator:

Proposition 18: Salaries and non-specified monetary prizes are likely to stimulate the performance of the induced curiosity scholars.

Two methods exist to organize induced curiosity research. The more common method consists of hiring a researcher who is paid a salary. This method entails substantial monitoring and evaluation costs. The other method is the use of monetary prizes to induce scholars to investigate problems, which the sponsor is curious about. A system of prizes can be set up for two objectives, namely to make specific discoveries or to stimulate unspecified scientific progress. The specific prize is a way of directing research efforts towards some specific. end without planning the research activity: itself. ${ }^{314}$ However, as the specificity of the requirements increases, so does the specificity of the scientific output that will be rewarded. Because a scholar often does not know what will come out of his research, it becomes more uncertain whether the scholar will meet the specifications. So, the uncertainty about income increases also. In the end, it may prevent him from entering into scientific activity. Salaries and non-

314. Direct rewards can stimulate scholars to undertake research, resulting in minor, practical discoveries which are not patentable. 
specified awards seem, therefore, more appropriate to stimulate the research activity of these scholars.

Proposition 19: Non-specified awards may provide a stimulus for basic research, much as the patent system works for applied research.

The non-specified award seems more suitable for basic research, because the patent is already a non-specified reward for research in the applied field. Of course, the usefulness of the method is dependent on the quality of the decision process in the awarding of the prize.

Althoff set up a combined salary-prize system. The less productive scholars obtained a fixed salary, while brilliant scholars could earn high salaries and lecture fees. Marks of honor and research facilities were part of the compensation package of Prussian scholars as well. Althoff became legendary in providing brilliant scholars like Koch, Ehrlich and Behring with excellent research facilities. Top scholars were given their own independent research institutes, since they did not have to be monitored that closely. In the Althoff era, the Nobel Prizes already existed. Many researchers who worked at German academic institutes won the prestigious prize. ${ }^{315}$ Althoff also used his own system of non-specified rewards, namely titles and marks of honor. Their incentive value has to be understood in the cultural and societal context of the time. They were a cheap, yet very effective, compensation instrument.

\subsubsection{Academic Tenure}

Proposition 20: Tenure is likely to lower academic performance, unless the scientific community continues to perform its auditing and disciplinary role.

Economic theory shows that nonprofit organizations such as universities tend to spend more in the work environment than for-profit organizations because they cannot distribute the financial residual. Due to the nature of the academic residual, even forprofit universities would have great difficulty in capturing the residual. Therefore, the members of these organizations have little incentive to reduce costs and instead try to improve working conditions, including job security. ${ }^{316} \mathrm{~A}$ specific aspect of the academic labor conditions is tenure. The tenure system is said to have two advantages: it saves the universities money in the short run and it provides some elementary protection for minority opinions. An important incentive to be productive may, however, disappear.

Professors may be willing to accept a lower wage if they are protected against discharge. In this respect, the university administrator can reduce wage payments. In the long run, however, tenure may reduce the incentive for faculty members to stay

315. See conclusion 2.

316. Armen A. Alchian (1958), "Private Property and the Relative Cost of Tenure", in: Economic Forces at Work (1977), Liberty Fund, Indianapolis, pp. 177-202. 
productive. In that case, it will increase the costs of academic production. While the possibility of getting dismissed for reasons of malperformance tends to keep scholars productive, some faculty members may enter a period of quasi-retirement once they are granted tenure. Since an important incentive to keep performing well has disappeared, the tenure system may result in inefficient scholarly behavior.

The second argument in favor of tenure is that job security permits scholars to take unpopular views.

"Tenure is a formal, institutional constraint that lowers the cost of acting on one's conviction. ${ }^{317}$

In that case, tenure should apply to the start of a scholarly career, since new and radical ideas are most likely to occur at the beginning of a career. However, this is not the period when tenure is usually granted. According to Carmichacl, tenure is awarded to protect the tenured professor from his colleagues. ${ }^{31}$ His argument in. favor of tenure rests on the crucial assumption that faculty members are better informed than the administration about the quality of new candidates. ${ }^{39}$ Therefore, tenure is awarded in order to increase the probability that the tenured faculty selects the best new candidates. If current faculty members were to be evaluated relative to the new faculty members they were about to appoint, they might have an incentive to be inaccurate in their judgements about candidates. Therefore, tenure is an efficient solution, because, without it, professors would never be willing to appoint scholars. who might turn out to be better than themselves. However, following proposition 13 , even tenured faculty members act rationally when they stay unfamiliar with the: credentials of the candidate. Carmichael argues that the abolition of tenure would reduce the career prospects of very brilliant young scholars, unless the administration began to devote time and effort to the screening of applicants. ${ }^{320}$

Tenure is said to protect, academic freedom and to make sure that the truth is sought and taught. Untenured scholars, however, have considerable freedom to disagree with their superiors. One reason is that most scholars are genuinely curious and interested in the advancement of science. However, a scholar who disagrees sufficiently with his. professors, may find his career prospects reduced, even though he is consistently.

317. Armen A. Alchian and Susan Woodward (1987), "Reflections on the Theory of the Firm": Journal of Institutional and Theoretical Economics I43, pp. II0-137.

318. H. Lorne Carmichael (1988), "Incentives in Academics: Why is There Tenure ?", Journal of Political Economy 96, no, 3, pp. 453-472.

319. Carmichael's assumption is in clear contrast with proposition 13.

320. This is precisely what the Althoff system did. Carmichael believes, however, that the selection of candidates is a task that is best left to the experts in the faculty. The academic network of Althoff was set up, however, exactly because the experts typically work at different locations in different academic institutes. 
right. ${ }^{321}$ Nevertheless, faculty is under great pressure from the rest of the scientific community to tolerate considerable freedom for the young scholar. ${ }^{\text {m }}$

"Thus, an independent young man may well develop considerable assets in the form of outside respect. If he is badly treated by his own department, he can normally easily move elsewhere. Only the less productive scientist need worry about the feelings of his immediate superiors. For the man who really does have independent ideas which work out well, there are innumerable alternative employers. Although he has no tenure, he is safe as long as he produces. "123

Although most academics, even with tenure, avoid actions which might seriously affect the financial situation of their institutions, tenure may be of some use to an administrator who wants to protect his academic employees against undue dismissal by the sponsor.

It has been argued that the work load of tenured faculty may gradually erode in the long run. Some continue to do research, possibly of improved quality, but some stop and a great number slow down. ${ }^{\text {nat }}$ However, this depends largely on the pressure they are under to perform and to perform well. The pressure, which is exercised by the scientific community, is such that it maintains high academic standards and performance. If the scientific community functions well, it induces scholars to keep publishing. When tenured faculty are able to isolate themselves from the scientific community, their productivity is likely to erode.

Proposition 21: Academic tenure may entail substantial rent-seeking costs as well as benefits.

Rent-seeking is the socially unproductive activity that seeks to capture part of the social surplus by obtaining a higher compensation than would be required by competitive market forces. The traditional example of a rent-seeking activity is the lobbying of government to obtain an exclusive license in order to create a monopoly that will permit the charging of prices above the competitive level. The concept was

321. In The Organization of Inquiry, Tullock gives the example of Albert Einstein. He had not impressed his professors enough to be offered an academic job after graduation. Instead, Einstein was forced to take a job in the Swiss Patent Office. There, he could spend most of his time each day on matters of interest to him and developed the special theory of relativity. However, Einstein is also the prime example that a man who is consistently right gets other opportunities from members of the scientific community. Einstein was awarded a full professorship of physics in 1905 and the directorship of the Kaiser-Wilhelm Institute for Physics in 1913.

322. Another opportunity for the scholar, who does not fit into the prevailing academic system, is amateurism. Being under less time pressure, these scholars can often work matters through thoroughly.

323. Gordon Tullock (1966), Organizarion of Inquiry, p. 217.

324. See: Armen A. Alchian (1958), Tenure, pp. 177-202. 
introduced by Gordon Tullock, while the term was coined by Anne Krueger. ${ }^{325}$ McKenzie applied rent-seeking theory to academic behavior. ${ }^{306}$ His departmental model can easily be extended. to the academic system as a whole. McKenzie argues that the amount of salary increases available to the academic administrator is a fixed sum, which is unrelated to productivity, i.e. there exists a wage fund. Within the academic organization, the fund is distributed in accordance with the relative productivity of scholars. A faculty member thus has two methods to increase his salary: he can increase his own academic productivity or he can decrease the productivity of the others. Decreasing the productivity of others is an example of rent-seeking. ${ }^{227}$

Brennan and Tollison also adopted the wage fund approach at the departmental level. ${ }^{22}$ They assume that department heads decide on salary increases, seeking to maximize the academic worth of the department. The academic worth of a faculty member is equal to the highest salary offer that the faculty member could generate from any other university or academic institute. A department head with perfect information would pay each faculty member exactly his reservation wage. ${ }^{\text {na }}$ Since the department head does not have perfect information. on individual reservation wages, the rent-seeking faculty member has an incentive to make the reservation wage seem higher than it actually is.

Again, this can be done in a variety of ways: exaggerating the attractiveness of outside offers or complaining about the current location. Other possible rent-seeking strategies are: searching for better-paid jobs, making other offers public, emphasizing the prestige of the alternative institute or indicating to the administration that moving costs are low. Assuming that scholars are willing to move in response to a better salary offer made by an academic institution of comparable rank, Robert Frank argues that the observed stability in the hierarchy of departments implies that professors in those departments are paid their marginal products. ${ }^{30}$ In fact, they are paid their reservation wage, which may not be even a close approximation of their marginal productivity. ${ }^{33 !}$ Although mobility is penalized to the extent that the uncertainty of production induces employers to underpay new faculty, the productive scholars, who

325. Gordon Tullock (1967), "Welfare Costs of Tariffs, Monopolies and Theft", Western Economic Journal 5, pp. 224-232, and A.O. Krueger (1974), "The Political Economy of the RentSeeking Society", American Economic Review 64, pp. 291-303.

326. Richard B. Mckenzie (1979), "The Economic Basis of Departmental Discord in Academe", Social Science Quarterly 59, no, 4, pp. 653-664.

327. The creation of unnecessary committee work in order to waste the time of the productive scholars is an example of rent-seeking.

328. H. Geoffrey Brennan and Robert D. Tollison (1980), "Rent Seeking in Academia", in: James M. Buchanan, Robert D. Tollison and Gordon Tullock (eds.), Toward a Theory of the RentSeeking Society, Texas A \& M University Press, pp. 345-356.

329. Because individual's cannot move to other employments without cost, it is possible to pay a scholar a lower salary than he could earn in a comparable university. Since mobility costs differ between individuals, they generate different locational rents.

330. Robert H. Frank (1984), "Are Workers Paid Their Marginal Products ?", American Economic Review 74, no. 4, pp. 549-571.

331. See proposition 16. 
are likely to receive offers from other employers, are more willing to move, because of the discrepancy between their wages and academic: productivity. ${ }^{332}$

Talented scholars might have a higher opportunity cost of their time than their colleagues, because they are more engaged in research. As a result, the latter are more likely to serve and participate in committees. Therefore, the latter have a greater influence on formal professional standards and on hiring, promotion and salary decisions, than would be warranted by their numbers and ability alone. ${ }^{303}$

Tenure may be a source of waste and inefficiency if rent-seeking takes place. To obtain a tenured position, scholars may undertake wasteful activities like lobbying academic authorities and influential academics. While rent-seeking creates welfare losses when the activities to capture the rent are socially unproductive, it can also create social benefits if the right to capture the rent is obtained by socially beneficial actions. ${ }^{34}$ For example, to obtain a production. licence or patent in the pharmaceutical industry, potential monopolists engage in valuable research, which may result in the production of a drug. This research would not have taken place if the pharmaceutical firm was not granted a temporary monopoly patent. ${ }^{35}$ If tenure induces risk-averse scholars to engage in high-quality research, then rent-seeking may entail substantial social gains.

Proposition 22: Tenure protects the idiosyncratic investments of the tenured scholar.

Although tenure may lower academic performance in the long run and may entail rent-seeking costs, Peirce has suggested that tenure is a precondition for those academics who are invited to suggest cost cuts. They must be sure that they will not be made redundant as a consequence of their own cost cutting proposals. ${ }^{336}$ In general, the rationale for tenure rests on the concept of firm-specific human capital. While research and teaching skills with few exceptions are not university-specific, administrative tasks often are. Scholars who at a higher age tend to be less productive, may engage more in academic administration and management. So, they are granted tenure in order to protect firm-specific human capital.

Another rationale for tenure is the protection of the costs that are made to establish a research program. The chairholder or institute director, who invests time and effort in building a team of qualified scholars or establishing a coherent research program, is vulnerable to a hold-up situation and may become a victim of opportunistic behavior from the administration. A way of protecting himself is to stay in the academic labor

332. Armen Alchian, Tenure, p. 190 and 191.

333. Herbert G. Grubel and Lawrence A. Boland (1986), "On the Efficient Use of Mathematics in Economics: Some Theory, Facts and Results of an Opinion Survey", Kyllos 39, pp, 419-442.

334. Thomas 3. DiLorenzo (1988), "Property Rights, Information Costs and the Economicsi of RentSeeking". Journal of Institutional and Theoretical Economics 144, no. 2, pp. 318-332.

335. Jürgen Backhaus (1983), "Competition, Innovation and Regulation in the Pharmaceutical Industry", Managerial and Decision Economics 4, no. 2, pp. 107-121.

336. William S. Peirce (1983), "Repealing Parkinson's Law: Incentives to Encourage Bureaucrats to Save the Taxpayers' Money", Research Paper, Case Western Reserve University, 51 pp. 
market continuously, but this hampers the development of the long-term research projects that require this type of investments. The value of idiosyncratic "specific investments depends to a large extent on the continued cooperation of one party with a specific party. Under some circumstances, these specific assets can be protected by contingent contracts. However, if transaction costs are high, tenure may be an. efficient solution for reducing opportunistic behavior towards scholars with specific investments, ${ }^{39}$

Nevertheless, the threat of termination of the contract serves as an incentive to the employee to keep pursuing the goals desired by the employer, i.e. the production of new knowledge. ${ }^{3:}$ Tenure should not imply that scholars stop producing. However, this depends to a large extent on the auditing and disciplinary efforts of the scientific community.

Hypothesis 10: The Althoff system reduced the disadvantages of academic tenure.

Scholars who were appointed at Prussian academic institutes, were state bureaucrats with life-long tenure. However, academic freedom was also guaranteed by the. Prussian constitution. The Ministry of Culture acted as an effective safeguard against political interferences and commercial pressure. ${ }^{339}$ The system of private lectureships was another protection against state interferences. ${ }^{340}$ Following. hypothesis $I$, the scientific community played a crucial role in the Althoff system and kept the Prussian academics under great pressure to perform well. Since scholars. were appointed on the basis of their scientific merit, it is likely that academic tenure created substantial rent-seeking benefits. Since many administrative tasks were carried out by the central professional bureaucracy, a lot of committee work at the faculty level was reduced, which implied less opportunity for typical rent-seeking actions.

\subsubsection{Teaching and Research}

Academic output consists of different products: research, teaching, university management and social service. In most models, scholars are considered to produce two goods: research and teaching. Whether these goods are complements or substitutes is still an issue of dispute. ${ }^{34 !}$ Wilhelm von Humboldt's principle, which favors the complementarity idea, has long influenced the ideas about academic

337. Oliver Hart and John Moore (1990), "Property Rights and the Nature of the Firm", Journal of Political Economy 98 , no. 6, p. 1133.

338. Jürgen G. Backhaus (1989d), "Workers' Participation Stimulated by the Economic Failure of Traditional Organization", Research Memorandum 89.11, University of Limburg, 39 pp.

339. See observation 31 .

340. Arons was dismissed as a private lecturer because he was a member of the "subversive" SDP. Although Althoff did the utmost, he could not prevent this particular dismissal. As a result of his resistance, Althoff did succeed, however, in improving the financial and statutory position of the private lecturers in general.

341. William E. Becker Jr. (1975), "The University Professor as, a Utility Maximizer and Producer of Learning, Research and Income", Journal of Human Resources 10, pp. 107-115. 
organization. Economic research on the academic production of both products has usually been carried out separately for each product. Lovell was one of the first to estimate production functions that contained measurements of research. performance. ${ }^{32}$ Other economists have estimated production functions using some measurement. of teaching effectiveness as output variable. ${ }^{43}$

Proposition 23: The salary system is better attuned to the dual academic production of teaching and research than is the (strict) fee system.

Adam Smith believed that universities would work more efficiently if wages for lecturers were to be derived from students' fees. ${ }^{34}$

"The endowments of schools and' colleges have necessarily diminished more or less. the necessity of application in the teachers. [...] Those parts of education, it is to be observed, for the teaching of which there are no public institutions, are generally the best taught. ${ }^{\text {ans }}$

Following Smith, Rosen has asked whether academic salaries should be more directly provided from lecture fees. His conclusion is that this might be right if teaching was the sole output of the university, but not if research is also an important output. ${ }^{346}$ Smith suggested a compensation method, which related the income of the professor to the teaching quality, assessed by the students. ${ }^{347} \mathrm{He}$ argued that salaries adversely affected the incentive to give good lectures, because the lacking threat of student. withdrawal diverted the attention of the lecturer away from the teaching task. However, lecturers seem to have an incentive to lower teaching quality irrespective of the fact that they are paid by salaries or by lecture fees. Fees give incentives for professors to increase course enrollments by making the course content easier and more popular ${ }^{348}$ Salaries provide incentives to reduce enrollment by making courses difficult and boring. Rosen concludes that a salary system and a fee system are approximately equivalent. Therefore, lecture fees were gradually replaced by salaries to reduce transaction costs, i.e.

"I..) to avoid the hassles of bill collecting, attracting a student clientele, and course scheduling, by rurning these duries over to a more centralized agency of nonteaching personnel and this, in turn, promoted uniform pricing practices within schools. ${ }^{3499}$

342. Michael C. Lovell (1973), Production of Economic Literature, pp. 27-55.

343. A summary of the research on teaching effectiveness is given, by Eric A. Hanushek: (1986), "The Economics of Schooling", Journal of Economic Literarure 24, no. 3, pp. 1141-1177.

344. E.G. West (1970), Education and the State, Institute of Economic Affairs, London, p. 120.

345. Adam Smith (1776), An Inquiry Into the Narure and Causes of the Wealth of Nations (1976), Clarendon Press, Oxford, p. 760.

346. Sherwin Rosen (1987), "Some Economics of Teaching", Journal of Labor Economics 5, no. 4,. pp. 561-575.

347. Smith assumes that teaching is readily measurable and that its quality can be accurately measured by the students.

348. The quality of the information, transmitted in a course, is likely to reduce as class size and student diversity increase because the professor has to address himself to the median student.

349. Sherwin Rosen (1987), Some Economics of Teaching, p. 566. 
In a strict fee system, a scholar's incentive to do research is his anticipated effect on the content of his lectures, hence on his future fees, paid by the students. It seems reasonable to suggest that investments in scientific research would be lower if academic activity was to be financed only through lecture fees. A professor, who would reveal original thoughts to students, would immediately create some fierce competition. Thus, the scholar might just as well use the ideas of others rather than invent new ones. The strict fee system would slow down the pace of scientific progress. In this respect, a salary system promotes the free dissemination of knowledge, which productive research demands. ${ }^{300}$ It does not necessarily promote the efficient allocation of a. scholar's time beteen teaching and research. ${ }^{31}$

Althoff maintained a mixed salary-lecture fee system. While the salary system promoted the free dissemination of knowledge, lecture fees created a strong incentive to self-monitor teaching quality. Althoff decided to tax part of the excessive lecture fees in order to strengthen the cooperative aspect of academic teaching. ${ }^{19}$. The receipts were also used to support unpaid faculty members. This had the effect of containing competition among professors for students, while strengthening the institute system.

Proposition 24: Teaching and research can be separated as long as academic output is freely disseminated.

In the university system, research is often organized and financed as a by-product of teaching. Scholars typically work at different institutions, dispersed according to the needs of the educational system since the number of employed scholars depends primarily' on the number of students that choose to enroll in certain courses. This may not be the most efficient allocation of resources, because teaching is frequently about the specific subfield, in which the scholar is doing research, instead of the broader area desirable for educational purposes. In other words, the combination of researchi and teaching may lower academic productivity and performance. Therefore, it seems desirable to some extent to leave the Humboldtian principle and to organize teaching and research in separate institutions. Althoff created many research institutes, in which scholars had no teaching obligations.

An effective educational system requires. teaching practices to pay' attention to new' and relevant developments in science, for which scholars heavily involved in research are the best source of information. One reason why a top scholar should give some classes is to avoid the possibility that scholars of less ability do not transmit the new information correctly. It is also valuable to some students to be exposed to knowledge at the leading edge. Future research projects have to recruit among the newly' educated, whose performance is also dependent on the quality of their formal

\section{See proposition 3 .}

351. Compensation, which is determined entirely by one aspect of academic output (teaching or research), tends to result in poor performance of the other.

352. Education is a complex activity, determined by the collective efforts of the teaching staff instead of one particular lecturer. 
education. Teaching and research are therefore understood as complementary and enhancing each other. In this respect, there is a need for teachers who are actively involved in scientific developments. It follows, however, that the academic authorities should consistently adhere to this policy because, if research is actually higher valued than teaching, rent-seeking scholars may try to shift the burden of teaching to others in order to decrease the research productivity of their colleagues.

A partial solution may be to leave teaching at the advanced and doctoral level to the research-oriented scholars, because it is understood to require the same abilities as research. Suppose graduate students would participate in the research program of a top scholar. This would generate benefits for both parties. The top scholar could still carry out his research program, while students would learn to do research even without any formal instruction. This concept was realized in the Prussian seminar method, which was systematically introduced in the Althoff system. Some doctoral programs are also good examples of a successful combination of teaching and research. 


\section{Bureaucratic Governance}

\subsection{Bureaucratic Control Loss}

Proposition 25: Loyalty and discipline reduce the monitoring costs of production.

Prop. 26: Structural bureaucratic inefficiency results from information distortions.

Prop. 27: Hierarchical loss of control is likely to occur when the span of control and the number of hierarchical levels increase.

Prop. 28: Economies of scale in information gathering can offset managerial overload.

Hypothesis 11: A manageable span of control and a comparative information advantage contained the bureaucratic costs of the Althoff system.

Prop. 29: The need for effective communication may offset information distortions.

Prop. 30: Academic performance is likely to be lower in the public sector unless the scientific community performs its auditing and disciplinary role.

\subsection{Authority}

Prop. 31: The authority of a bureaucrat depends on the ability to maximize the budget of the department in which he is working.

Prop. 32: If monitoring by the sponsor takes place in order to modify bureaucratic overexpansion, the authority of the bureaucrat depends on the ability to reduce the financial and review constraints.

Hyp. 12: The multi-source financing system strengthened Althoffs authority.

Prop. 33: Bureaucrats who forgo the standard forms of compensation, create an opportunity for independent behavior. 
Prop. 34: Professional ability and behavior strengthen the authority of a bureaucrat.

Hyp. 13: Althoff's authority was based on professionalism.

Prop. 35: Rational deference strengthens the authority of the informed bureaucrat.

\subsection{Networks}

Prop. 36: Bureaucratic performance is dependent on the informal services rendered to the bureau.

Prop. 37: Bureaucratic performance is dependent on the intensity and the extent of internal networks.

Hyp. 14: Althoff's network improved the performance of the bureaucratic and academic system.

Prop. 38: Continuity is likely to improve selective bureaucratic behavior.

\subsection{Public Entrepreneurship}

Prop. 39: A public entrepreneur has to acquire a sufficient degree of autonomy.

Prop. 40: Entrepreneurial capacity is determined by the extent and the intensity of the networks that are set up by the entrepreneur.

Hyp. 15: Althoff was a public entrepreneur. 


\section{Chapter 8: Bureaucratic Governance}

In the property-rights theory of the firm, there is a role for a central contracting party who specializes in monitoring performance. 153 While the central party takes the residual, the organization protects itself against poor management. ${ }^{334}$ When externalities can be captured, property rights are more fully exercised. This promotes an efficient allocation of resources. Following transaction cost theory, hierarchical institutions have a competitive advantage in monitoring costs and accomodate idiosyncratic investments and uncertain production.

The centralization of rights was accomplished by the independent research institute structure, but also by the Althoff system as a whole, with Althoff and the state bureaucracy trying to exercise coordinated control. It is in this sense that the bureaucratization of the academic system should be understood, since Althoff did not wish to abolish traditional faculty independence. ${ }^{359}$

Centralization and decentralization both entail specific benefits. Both impose as costs different forms of inconsistent action. While there is a positive effect of increased coordination in a bureaucracy, there are also costs related to bureaucratic behavior and organization. Before taking a closer look at how Althoff lowered the costs typically associated with a bureaucratic and hierarchical organization form, it should be taken into account that bureaucratic inefficiency can be the result of bureaucratic as well as political failure. The outcome of a bureaucratic production process is the result of a chain of choices and decisions, made in both the political and the bureaucratic system. Procedures adopted by the bureaucracy, which seem unproductive or inefficient, may be necessitated by the political system. ${ }^{366}$ Determining whether something is inefficiently produced or not requires that the political constraints, under which the bureaucracy operates, are clearly spelled out. Otherwise, bureaucratic inefficiency may be observed by simply assuming other aims than the goals achieved by the bureaucracy. ${ }^{357}$ When political interferences beyond the sponsor's need of monitoring the agency are taken into account, the presumption

353. Robert E. McCormick and Roger E. Meiners (1988), "University Governance: A Property Rights Perspective", Journal of Law and Economics 21, vol. 2, pp. 423-442.

354. Eugene F. Fama (1980)," Agency Problems and the Theory of the Firm", Journal of Polinical Economy 88, no. 2, pp. 288-307.

355. See observation 27.

356. See: William S. Peirce (1981a), Bureaucratic Failure and Public Expenditure, Academic Press, New York.

357. The political vacuum approach has its merits for showing internal inconsistencies in bureaucratic behavior. 
of inefficiency can only be held up by indicating the (lost) opportunities to circumvent these political constraints.

In the Althoff era, there were some appointments of mediocre scholars that were purely political decisions. ${ }^{38}$. It would be wrong to blame the Prussian bureaucracy for the outcome. However, Althoff was a master in circumventing political, financial and bureaucratic constraints. ${ }^{399}$ Therefore, if there were failures of science policy that lowered scientific performance, they can be accounted to Althoff and his staff more easily than should be done otherwise.

\subsection{Bureaucratic Control Loss}

The main objective of our research effort is to achieve a better understanding of the economics of science and scholarship. The Althoff bureaucracy was the institutional basis of the German academic system and is, therefore, a legitimate object of this study. Moreover, the Althoff system also contains some untypical characteristics of bureaucracy, which makes it an interesting case to test the economic theory of bureaucracy. Public choice scholars have revolutionized this field, which until them, had been dominated by the Weberian tradition. Following the work of Tullock, Downs and Niskanen, ${ }^{360}$ the traditional view of the rational, bureaucratic apparatus has been replaced by a model in which bureaucrats have their own private motives, according to which they behave. ${ }^{361}$ In public choice analysis, the attenuation of control as a result of information distortions makes bureaucracy a type of organization that is not typically associated with efficient, devoted and hard-working agents.

The Prussian bureaucracy in general, and the Ministry of Culture under Althoff in particular, are such untypical cases. The organizational efficiency of this department was certainly influenced by the Prussian tradition of personal devotion and military discipline. While these social values played an important role in the performance of the civil service, the economic approach takes a closer look at the institutional structure and the degree of entrepreneurship in the Prussian bureaucracy.

Proposition 25: Loyalty and discipline reduce the monitoring costs of production.

Monitoring costs can be kept minimal in an agency where tradition, convention and goal congruence have made the behavior of bureaucrats to a large extent

358. See observation 28 .

359. As illustrated by observations 2,7 and 32 .

360. See: Gordon Tullock (1965). The Politics of Bureaucracy. Pụblic Affairs Press, Washington; Anthony Downs (1967), Inside Bureaucracy, Little Brown, Boston; William Niskanen (1971), Bureaucracy and Representative Government, Aldine-Atherton, Chicago.

361. The rationality of bureaucratic administration is not synonymous with efficiency. In the Weberian tradition, efficiency is assumed to follow either from the knowledge and skills of dedicated bureaucrats or from the rational and systematic structuring of decision-making . 
predictable. ${ }^{\mathrm{Na}}$ If agency members have a common ideology, which expresses the purposes of the organization, they can refer back to this aim in order to keep their own behavior in line with purposes. Goal congruence is said to increase the effectiveness of management by decreasing the burden of hierarchical supervision. Team spirit, mutual trust and loyalty are examples of attaining goal congruence. The internalization of such values could compensate for structural bureaucratic inefficiency.

The Prussian tradition of military discipline is an element that definitely enhanced the efficiency of Althoff's department UI and the academic system. Moreover, Althoff could rely on a team of loyal department members.

Proposition 26: Structural bureaucratic inefficiency results from information distortions.

The early theories of bureaucracy were constructed on the idea of a rational organizational structure, in which impartial civil servants were concerned with serving the public interest. Public choice theory has analyzed the internal organization of bureaucracy, noting the loss of control associated with this form of economic organization. An early challenge to the prevailing bureaucratic theory was offered by Anthony Downs, who described five different types of bureaucrats. ${ }^{363}$ However, as Peirce pointed out, this rich typology

" [...] rationalizes everything and predicts nothing. The analyst needs a psychological examination of each bureaucrat before he can forecast the behavior of the individuals or the bureau. ${ }^{m 64}$

Tullock reduced the complex utility function of Downs into one dimension: the personal advancement of intrahierarchical climbers. His analysis is restricted to bureaucrats, who are able and determined to rise to the top ranks of the hierarchy. The model starts from the basic public choice assumption that individual bureaucrats also have private objectives and, when faced with a choice between furthering the purpose of the organization or advancing their own goals, often choose the latter.

To get a promotion, even the most able experts in the bureaucracy are dependent on the favorable opinion of their superiors. Therefore, they rationally seek to provide the information that they judge their superior wants to receive. ${ }^{365}$ In the constant process of adjusting the information transmitted up the hierarchy, the coordinator finally receives information from his staff which is more likely to resemble his initiall judgement rather than the facts. Moreover, most bureaucrats play the dual role of

362. T.L.C.M. Groot (1988), Management van Universiteiten, Wolters-Noordhoff, Groningen, p. 131 .

363. "Climbers" are primarily driven to enhance their own career, while "conservers" try to obtain power, income and prestige with the least possible effort. The other three categories are partly interested to promote the public intrest. "Zealots" are dedicated to implement a narrow policy, while "advocates" want to make efforts from which their own department benefits. "Statesmen" aim at broader goals, and are eventually willing to compromise.

364. William S. Peirce (1981b), "Bureaucratic Politics and the Labor Market", Public Cholce 37, p. 308.

365. Gordon Tullock (1966), Politics of Bureaucracy, p. 52. 
subordinate and superior. In the process of transforming policy into rules, regulations, formal procedures and informal practice, the content gradually evolves until it corresponds with the preferences of the agents. ${ }^{366}$ The results are twofold. There is a loss of control for the principal, because agents lower in the hierarchy selectively filter information upward in order to match the judgements of the principal, while orders from the top are gradually transformed to filt the circumstances and preferences of the agents. Of course, any top manager loses some degree of control, because he cannot know all activities in the organization. However, the control loss of bureaucracy is not as much the result of an information-processing overload, but rather due to structural distortions that occur as information is transmitted through the hierarchy. ${ }^{367}$

Proposition 27: Hierarchical loss of control is likely to occur when the span of control and the number of hierarchical levels increase.

Information distortions are a primary source of the attenuation of control in a bureaucratic organization. In a classical hierarchy, each agent is responsible to a single superior. In turn, he is the principal of a limited number of subordinate agents, who are reporting to him. This basic structure can be replicated in as many levels as necessary to perform the task of the organization. The number of agents of each superior at a particular level is called the span of control. Any element that decreases the span of control necessitates an increase in the number of hierarchical levels, given the number of agents to carry out the task. If some loss of control occurs at each level, performance departs further away from the purposes of the top management as levels are added to hierarchy. There is a tradeoff between span of control losses and level control losses. Given the tasks and the number of personnel specific to the organization, managers try to minimize the departure of operations from managerial intent. ${ }^{368}$

Proposition 28: Economies of scale in information gathering can offset managerial overload.

Work overload and control loss lead to inefficiency. ${ }^{369}$ When economies of scale in production are exhausted, average costs rise as the size of the organization is further increased. ${ }^{30}$ The absolute number of decisions, which the top manager has to make, increases proportionally, placing an ever larger burden on the top coordinator. Such administrative overload is likely to result in a deterioration of the decisionmaking quality. Administrative loss of control also results in increasing average costs.

366. William S. Peirce (1981a), Bureaucratic Fuilure, p. 26.

367. This cumulative distortion of information, which is called the control loss, increases with the number of levels it moves through.

368. William S. Peirce (1981a), Bureaucraric Failure, p. 20.

369. Oliver E. Williamson (1967), "Hierarchical Control and Optimum Firm Size", Journal of Political Economy 75, no. 2, pp. 123-138.

370. The optimum firm size theory is concerned with the formal structure of an organization. When applied to the workings of a public bureaucracy, the informal networks have to be taken into account as well. 
The distortion of information influences the quality of the principal's decisions as well as the content of the command passed down. It has been argued by Wilson that the economies of scale in formal and informal information collection are sufficiently important within the organization to offset administrative overload and control loss. ${ }^{371}$

Hypothesis 11: A manageable span of control and a comparative information advantage contained the bureaucratic costs of the Althoff system.

Along with the traditional Prussian discipline, a manageable span of control contained the costs associated with a bureaucratic form of organization. The Prussian Ministry of Culture was organized as a hierarchy that counted several levels. Althoff, who frequently bypassed his superiors, was the real manager of the department. ${ }^{37}$ This reduced the number of echelons, thus the level control loss. The number of levels under Althoff was rather small as a result of a clear division of tasks among fifteen referendaries. Although fifteen is not the optimal span of control that would be suggested by standard theory, ${ }^{373}$ their number did not increase in the Althoff era either. Bureaucratic mismanagement as a result of the great number of employees was reasonably contained in this way. The small size of the Althoff bureau eliminated some control problems associated with hierarchies. Althoff also maintained control of the department by assuming strategic tasks such as the recruitment of academic personnel and the procurement of financial resources.

Nevertheless, the work load was enormous. It took four bureaucrats to take over all of Althoff's formal duties following his retirement. Following the historical observations, it seems reasonable to suggest that there was some degree of work overload. Considering the results of the Althoff system, however, there seem to have been some offsetting effects. The comparative information advantage of the Althoff system resulted from an extensive informal network. ${ }^{374}$ Among other reasons, the breakdown of the system and the decline of German scholarship that followed, may have been the result of the truncation of the network necessary to run such a system. The truncation of the network was the logical consequence of the division of tasks and responsibilities which was meant to relieve the head of the agency from the total burden. But the decrease in managerial overload in the Ministry of Culture came at the loss of the economies of scale in the informal information processing capacity and, as a consequence, decision-making quality. This underscores the idea that it took an Althoff to run the system, which, in turn, makes the issue of bureaucratic behavior an important aspect of academic management.

Proposition 29: The need for effective communication may offset information distortions.

371. R. Wilson (1975), "Informational Economies. of Scale", Bell Journal of Economics 6, no. 1, pp. 184-195.

372. See observation 3.

373. Optimal is considered between 5 and 10 .

374. See observation 25 and hypothesis 5 . 
The attenuation of control in a bureaucracy is a structural information problem. To some extent, it is counterbalanced by the need of the bureaucrat to communicate effectively with the sponsor who allocates the available resources. Assuming that it takes an efficiently managed organization to market a product successfully, Breton and Wintrobe have argued that efficient departments have the best capacity to market their policies. They produce reports or release press articles that demonstrate the results of their programs or disprove allegations of inefficiency. ${ }^{375}$ Often the department head has informal relations with the bureaucrats, who are evaluating their programs on behalf of the sponsor. Although the performance evaluation studies produced by these departments tend to document its efficiency, a return to inefficiency always includes the risk of discovery and sanctions by the sponsors.

Althoff used many forms to promote the policies and achievements of his department. ${ }^{376}$ Being aware of the tactical importance of public relations for the existence and the viability of his department, he acquired his own journal. ${ }^{37}$ Althoff launched vigorous press campaigns, often without any immediate trace to his person and addressed himself directly to the sponsors in parliament on several occasions. As suggested by the exchange theory of bureaucracy. Althoff was in close contact with Germar, who worked as a referendary in the Ministry of Finance where he was responsible for the budget of the Ministry of Culture.

Proposition 30: Academic performance is likely to be lower in the public sector unless the scientific community performs its auditing and disciplinary role.

Peirce has conjectured that bureaucratic failure is more likely to persist than market inefficiencies because there exists no mechanism as strong as bankruptcy to discipline or eliminate inefficient behavior. ${ }^{378}$ Although there may be disagreement about the relative strength of alternative disciplining devices, it can be argued that the academic sector has a control mechanism that seems to operate with a comparable persistence. The auditing and disciplinary procedures of scientific production by the members of the community normally reduce the number of fraud cases and promote high-quality output. ${ }^{37 \%}$ In a competitive system, like the Althoff system, even low academic production is likely to attract as much negative attention as fraud and incompetence would.

375. Albert Breton and Ronald Wintrobe (1982), The Logic of Bureaucratic Conduct. An. Economic Analysis of Competition, Exchange, and Efficiency in Private and Public Organizations, Cambridge University Press, Cambridge.

376. See observation 11.

377. First, the respected journal Allgemeine Zeinung, later the specialized weekly Internationale Wochenschrift fur Wissenschaft, Kultur und Technik.

378. William S. Peirce (1981a), Bureaucratic Failure, p. 84.

379. Cfr. proposition 1. 


\subsection{Authority}

Althoff had an autocratic and energetic working style. Although he was not in the formal position to shape Prussia's science policy, he informally obtained the authority to do so..$^{360}$ To understand his authority and subsequent behavior, the institutional and financial constraints on discretionary power are studied. ${ }^{384}$ Frey points to several types of constraints that help to explain economic behavior: resources (e.g. the budget), formal institutional codes, informal norms and self-imposed constraints. ${ }^{\text {sa }}$ These constraints determine the range of activities of an individual. Taking these constraints into consideration constitutes the decisive stage in the behavioral decision process.

"The approach emphasizes that changes in behavior should be explained by changes in (observable), constraints (and not by usually non-observable or nonoperational changes in preferences). 300

In line with Frey, attention is given among others to the review constraint, the budget and promotion barriers.

However, the objectives of bureaucrats are often explicitly given in the economic models of bureaucratic behavior. In addition to the growing size of the (discretionary) budget and department, it has been suggested that the goals of bureaucrats are job security, promotion, avoidance of risk and responsibility, leisure or a personal conception of the public interest. ${ }^{344}$ While these models may have limited value to Frey, they are useful to the extent that they also point at the obstacles or constraints that the bureaucrat has to overcome in order to pursue some or all of these goals. ${ }^{385}$ Furubotn has even argued that the "entrepreneurial" Althoff can hardly be understood as a type of bureaucrat and seems to lie outside the scope of standard bureaucratic theory. ${ }^{336}$ However, Althoff was a bureaucrat, who held a major position in the Prussian administration. The economic theory of bureaucracy helps to explain which constraints he presumably had to overcome before he could acquire his autonomous. position and become a public entrepreneur. ${ }^{387}$

380. An organization is defined as bureaucratic if its employees have to act according to rules and instructions from above and are formally not allowed to use their own discretion or authority.

381. The economic approach to human behavior studies the individual preferences and constraints, taking changes in constraints to be the driving force for human action. Instead of imposing ad hoc motivational assumptions of bureaucrats, it studies how exogenous or induced changes in institutional and financial constraints affect bureaucratic behavior.

382. Bruno S. Frey (1986), "Human Behavior: Possibilities Explain Action", Journal of Economic Psychology 7, p. 140 .

383. ibidem, p. 150.

384. In the classic model, the bureaucrat follows orders. In Tullock's model, the bureaucrat wants to climb through the ranks by means of distorting information, while the Niskanen bureaucrat maximizes personal objectives by maximizing the budget of his bureau.

385i. The budget-maximization model, for example, also looks at the effect of the sponsor's review process on budget-maximizing bureaucrats.

386. Eirik Furubotn (1989), An Economic Analysis of the Althoff System: Comments, Discussion Paper Althoff Conference, Heilbronn, p. 6.

387. See proposition 39 . 
In the economic literature, there are several models for the analysis of bureaucratic behavior. Niskanen focuses on the budget determination process and stresses allocative failure in bureaucratic organizations. Tullock analyzes the internal processes of bureaucracy and finds that the incentives facing individual bureaucrats tend to lead to a loss of control. Peirce discusses the issue of professionalism by comparing the internal labor market and outside job opportunities for public officials. Buchanan and Vanberg look at the calculus of rational agents who defer to a principal. Breton and Wintrobe look at the informal services delivered within the administration and claim they are a determinant of selective, i.e. efficient or inefficient behavior.

Proposition 31: The authority of a bureaucrat depends on the ability to maximize the budget of the department in which he is working.

Niskanen subjected bureaucracy to a comprehensive analysis, based on the selfseeking assumptions of public choice. He focused on bureaucrats, who exercise responsibility over budgets. Their bargaining position for their own salary increases is weak due to the fact that bureaucracies are mostly long-term contracting institutions that often use a wage scale system. This means that the wage level is dependent on internal promotion, which is usually granted on the basis of seniority. Furthermore, if the agency produces public goods, the assessment of the bureaucrat's marginal revenue product is particularly hard to make. Instead of salary, other variables like prestige, office perquisites and discretionary power enter the utility function of the top bureaucrats. According to Niskanen, these variables are associated with the size of the budget. Therefore, budget maximization serves as a proxy to the maximization of personal utility. It becomes the aim of the leading bureaucrat. Reputation, discretionary power and authority are an increasing function of the total budget of the department.

Budget maximization implies allocative efficiency losses due to oversupply. ${ }^{388}$ A program with total costs exceeding total benefits is not likely to be sustained by the sponsor. In the basic Niskanen model, the bureaucratic failure is allocative, but many qualifications are discussed. By assuming that output is produced with technical efficiency, a vast range of problems that are associated with bureaucratic production is abstracted from.

The German academic system expanded rapidly during Althoff's time. The Prussian Ministry of Culture was also the largest department. It absorbed more than a quarter of total public expenditures. Aithough the size and the expansion of his department might explain his growing reputation and authority. Althoff does not fit the characteristics of the Niskanen bureaucrat. The Althoff system was essentially demand driven. The traditional university system was breaking down under the growing

388. It should be remembered that the supply of public goods exceeds the volume that would maximize the utility of the sponsor.

389. If budget-maximizing bureaucrats have to deliver a larger quantity of the public service in order to obtain larger budgets from the sponsor, they have an incentive to run their agencies technically efficiently. 
demand for more research and higher education. ${ }^{300}$ The oversupply model of Niskanen is, therefore, not the most appropriate model. ${ }^{\text {n1 }}$

Indeed, in spite of the growing budget, the allocative inefficiency that follows from budget maximization seems not to have been the case. Since Althoff's department was in the budget constrained region, the growing financial needs were met by attracting private funds, i.e. off the budget. Unlike the Minister of Finance, who finds it hard to assess the true costs of public output, private sponsors know exactly the private opportunity costs of the public good they finance. In contrast, it is comparatively difficult for bureaucrats to estimate the true value to the citizens of their services. The observation that Althoff was very effective in raising private funds, indicates that allocative failure was not perceived so substantial as to divert the private resources to other, more efficient ventures. Although research institutes and universities could be run as private organizations, German bankers and captains-of-industry voluntarily made substantial contributions to public research programs.

Proposition 32: If monitoring by the sponsor takes place in order to modify bureaucratic overexpansion, the authority of the bureaucrat depends on the ability to reduce the financial and review constraints.

The most important qualification which Niskanen makes to the basic model is the role of the review process by the sponsor. When government monitoring takes place, it is likely to modify the overexpansion of the state agency, although political sponsors typically are more concerned with reelection issues than with monitoring bureaus. ${ }^{32}$ Of course, other incentives than reelection may motivate the review committee members. The leading bureaucrats also have a strong interest in the performance of their department.

"It is hypothesized that an official can increase his (bargaining) power by forming alliances which means that the official must make his own goals consistent with those that are widely shared; that is, the public interest. ${ }^{293}$

390. A rapidly growing number of students enrolled in some form of higher education to satisfy the demand for well-trained academics in industry and government. Spurred by the industrial. revolution and international competition, more research also took place.

391. While yielding strong theoretical conclusions, Niskanen bureaucrats can behave only in accordance with the motivational assumptions and in response to measurable changes. This deprives the bureaucrat of a real choice whether to act efficiently or not. Therefore, Niskanen gives several qualifications to the basic budget-maximization model.

392. Niskanen argues that the sponsor's comparative information disadvantage tends to divert him away from his monitoring responsibilities. Quite often, the sponsor does not have the information pertaining to the true costs of public production. In contrast, it is comparatively easy for bureaucrats to estimate the value of their production to the politicians. Although the interests of sponsors and bureaucrats might be different, the costs of an effective review make sponsors accept the budget-output proposals of the bureaucrats. The rational sponsor may not want to bear the individual costs of monitoring if the benefits go to the whole population as a function of their tax costs.

393. William S. Peirce (1981a), Bureaucratic Failure, p. 83. 
Even without effective monitoring by the sponsor, there are clear limits to the expansion of a bureau's budget. When the budget-maximizing bureaus have to compete for public resources, they can expand only in response to an increase in the relative demand for their services. Furthermore, when the sponsor believes that the information from a bureau is distorted, he might rationally allocate fewer resources to the bureau. The mobility of bureaucrats also constrains the growth of budgets, because the most effective way to obtain a larger budget may be to move to a larger department rather than to attempt to expand the budget of the department in which one is currently working. The leading bureaucrats may even be willing to expend less as long as they can retain a discretionary budget. ${ }^{394}$

Hypothesis 12: The multi-source financing system strengthened Althoff's authority.

In Prussia, public opinion was becoming increasingly aware that knowledge also was a factor of production. At the time, a new term was coined: "science policy". Indeed, politicians took a particular interest in the German academic system, ${ }^{305}$ because they had clear reelection incentives to do so. Other motives, like the international recognition of German science and scholarship and the growth of the tax base, also stimulated politicians to monitor the performance of the academic system. ${ }^{3 \%}$ Bilateral negotiations with the Finance Ministry were closely scrutinized. If the private donations to the public academic sector are seen as voluntary tax payments or Lindahl prices, the allocation of resources before the voluntary taxation was nonoptimal. ${ }^{397}$ Nevertheless, it was a rational decision of the Minister of Finance to underprovide resources. Althoff stayed in the same department for twenty-five years. For the mobility argument to hold, Althoff's department had to be the largest, which it was. Although a discretionary budget may provide a certain amount of satisfaction to the top bureaucrat, it should be reminded that higher output increases the likelihood of further budget increases by the public sponsor. Among other grounds, the authority of a bureaucrat depends on the financial independence of his agency. Financial independence includes two aspects: generation of off-budget revenues or exemption from audit. Althoff's multi-source financing system also generated revenues from private sponsors, which strengthened the autonomous position of Althoff in the Prussian administration.

Proposition 33: Bureaucrats who forgo the standard forms of compensation, create an opportunity for independent behavior.

A bureaucrat who has chosen to disregard the consequences of a decision for his own career is no longer constrained by his superior's orders or by the agency's rules and

394. J. Migué and G. Belanger (1974), "Toward a General Theory of Managerial Discretion", Public Choice 17, pp. 27-43.

395. Observation 11 noted that Althoff addressed the Prussian parliament several times defending the science policy of the Ministry of Culture.

396. See observation 4 and proposition. 15 .

397. Richard Abel Musgrave (1938), "The Voluntary Exchange Theory of Public Economy", Quarterly Journal of Economics 53, no. 2, pp. 213-237. 
procedures. Such independent behavior can be explained by the fact that utilitymaximizing behavior is motivated by a compelling goal, overriding traditional incentives, such as job security and promotion. Following this option, the bureaucrat performs his tasks in such a way that his actions have a positive or neutral impact on that particular aim, but which does not necessarily have to coincide with his superior's aim. ${ }^{30}$ Independent behavior can also be explained by the bureaucrat's successful lifting of institutional and bureaucratic constraints. Supposing his actions and decisions clash with the views of his superior, he can still pursue his own ends, if he manages to bypass his superior. This requires the support of a superior who works at least two levels higher in hierarchy, i.e. a superior of his superior. Forgoing the standard set of administrative rewards also creates some operational room for personal initiative. Having reached the appropriate formal position in the hierarchy from which to pursue some own goals, promotion perspectives are less capable of disciplining the bureaucrat's behavior.

Proposition 34: Professional ability and behavior strengthen the authority of a bureaucrat.

A bureaucrat is likely to be more willing to take the risk of dismissal, if he has one or more opportunities outside his department. Autocratic behavior, like Althoff's "personal regime", ${ }^{99 \%}$ is therefore determined by opportunity cost. Peirce recognized that

"the literature on the behavior of individuals within the bureau ignores the jobs outside the bureau to which the individual might shift. This neglect is unfortunate because the best choice open to the bureaucrat outside the bureau defines the opportunity cosit of independent behavior within the bureau.

Buchanan demonstrated at length that the forgone value of the best alternative is the only measure of value when there exists no competitive market. ${ }^{401}$ Forgone job alternatives determine opportunity costs, which give proximate evidence of the value of current labor performance. The opportunity cost, i.e. the best offer obtained from a different employer, increases by performing in such a way as to maintain the respect of others in the profession. A professional is a person for whom the cost of leaving his current job is neglible. The implication is that the professional, unlike the climber, does not have to compromise on his own opinion. The professional bureaucrat is not forced to give his superior the information the latter wants to hear, because he can find another employer who will reward him for his professional integrity and ability. Professionals have a primary commitment to their profession, rather than to the organization. The existence of an outside labor market permits the individual to keep up professional standards.

398. Economists would not consider a psychological examination of the bureaucrat's motivation scheme to be particularly useful, but an attempt can always be made. See: Bernhard Rothman and Charles Strein (1982), "The University Administrator as a Utility Maximizer", Rivista Internazionale di Scienze Economiche e Commerciali 29, no. 5, pp. 451-464.

399. See observation 2.

400. William S. Peirce (1981b), Bureaucraric Politics and Labor Market, p. 308.

401. James Buchanan (1969), Cost and Choice, Markham, Chicago. 
Hypothesis 13: Althoff's authority was based on professionalism.

Althoff had gained the support of the Emperor and many politicians of different parties. This allowed him to bypass his superiors, the Undersecretary and Minister of Culture. At times when there was considerable pressure on his position, he was strongly backed by the Emperor and political friends in parliament. Althoff rejected an offer to become Minister of Culture twice and stayed within the state bureaucracy. Job security might have played a role in his decision. His refusal of further promotion not only made him independent of the instability of political life, but also created the opportunity for independent behavior from which to counter e.g. the opposition of certain academic interest groups.

Following the first option of explaining independent behavior, it should be recalled that Althoff and many contemporaries, in the spirit of the times, were personally devoted to the international recognition of German science and scholarship. This goal was a driving force behind Althoff and the Althoff system, overriding other concerns. The question why the Emperor and certain politicians wanted to back lower staff may be a matter of rational deference. ${ }^{\mathrm{c}}{ }^{\mathrm{I}}$ It is known that the Emperor liked Althoff as a person for his devotion and sense of humor. With the German public opinion focused on scientific progress, Althoff was just the man to turn to. One obvious reason why Althoff was allowed to follow his own path was that, by promoting, German science and scholarship, he promoted a broader goal of the top officials, namely the recognition of Prussia, in the world.

Professionalism in a bureaticracy can be assessed by taking into consideration the opportunity cost of staying in the administration. Soon after Althoff's death, his staff members Friedrich Schmidt-Ott and Ernst Eilsberger accepted top jobs in the chemical industry. ${ }^{403}$ This gives some evidence of their management capacities and the quality of their work in the public administration. Althoff himself was offered chairs of Law by the universities of Straßburg and Bonn. He was also asked to become Minister of Culture. These were highly-regarded positions, but more, important these outside offers enabled Althoff to maintain professional standards within the bureau. Professional control by the scientific community was incorporated in Althoff's academic policy. Offers and counteroffers from foreign universities gave Althoff some evidence about the opportunity cost for the scholar.

Proposition 35: Rational deference strengthens the authority of the informed bureaucrat.

Buchanan and Vanberg developed a model of rational choice to cover the behavior of persons who are observed to invest scarce resources, particularly time and intellectual energy, in becoming more fully informed about alternatives. The model is applied to the behavior of persons who are observed to defer to the opinions of those who do

402. See proposition 35 .

403. Schmidt-Ott went to Bayer Chemicals, Eilsberger to Solvaywerke AG. 
choose to become more fully informed. ${ }^{404}$ Individuals may choose to become followers of an intellectual leader. This leader earns their deference on his own differential investment in the acquisition of knowledge.

To seek to oust Althoff would have involved an enormous investment in time and resources, in order to obtain an information advantage over the Althoff system. The model of Buchanan and Vanberg, therefore, rationalizes the deference of the Minister of Culture, the rest of the staff and the academics, in spite of the fact that Althoff was not always in the formal position to command.

\subsection{Networks}

Proposition 36: Bureaucratic performance is dependent on the informal services rendered to the bureau.

The formal structure of a bureaucracy determines the official distribution of tasks, the rules designed to regulate the behavior of the bureaucrats, and the official lines of command and authority. Breton and Wintrobe have refocused the discussion of bureaucratic behavior away from authority and control toward exchange and competition. ${ }^{406}$ Basically, they argue that a bureaucracy cannot operate efficiently on the basis of authority alone. Loyalty, internal cooperation as well as competition between members of so-called bureaucratic networks play an important role in practice. The authority of a bureaucrat is not only related to his hierarchical position, but also to his ability to obtain, control, distort and restore information. The distortion of information occurs along the lines of the formal structure and creates a loss of control. The typical monitoring and control mechanisms associated with the formal structure are often expensive and mostly imperfect.

Therefore, the principal's need for accurate information is often satisfied by bypassing the formal structure, i.e. by obtaining and delivering informal services. According to Breton and Wintrobe, the exchange of informal services is a characteristic feature of bureaucracy that determines its productivity. Exchange of goods and services requires the existence of property rights, which are hard to establish in the case of bureaucratic relationships because the value and quality of the informal services are difficult to measure. Therefore,

"whereas market exchange requires law-based property rights, (bureaucratic) network exchange necessitates trust-based property rights". 407

404. James. M. Buchanan and Victor Vanberg (1989), "A Theory of Leadership and Deference in Constitutional Construction", Public Choice 61, pp. 15-27.

405. Cfr: observation 7.

406. Breton and Wintrobe (1982), Logic of Bureaucratic Conduct.

407. ibidem, p. 61 . 
Supported by trust, bureaucrats are linked with each other by more or less strong ties. These networks in the organization are referred to as the informal structure. ${ }^{408}$

Proposition 37: Bureaucratic performance is dependent on the intensity and the extent of internal networks.

The productive capacity of bureaucratic organizations is determined by the informal services that are rendered within and among bureaus. The essence of the BretonWintrobe theory is that bureaucrats choose whether to be efficient or not. This selective behavior is the outcome of an exchange process, determined by the rewards for informal services relative to the cost of acting inefficiently. Efficiency in a bureaucracy is defined as

"I.. / the cooperation of subordinates with their superiors to achieve the superiors' goals. $=09$

By intensity is meant the degree of cooperation between the bureaucrats, including the value of the services exchanged. The intensity of the network depends on the volume of trust accumulated between sponsors and bureaucrats and among bureaucrats. Trust in networks accumulates partly as a result of the response of an individual who forgoes opportunism. When trust accumulates and monitoring costs fall, the problem of incentives is also reduced in networks. Breton and Wintrobe argue that

"to the extent that every member is able to accumulate an optimum amount of trust, the problem of incentives does not exist". 410

The size of a network is proportional to the flow of informal services produced and supplied by that network. Informal contacts have to be sufficiently large to produce relevant information.

"Social lines of demarcation, which produce network truncation, are real barriers in the sense that it requires the use of real resources to overcome them. ${ }^{241 .}$ Common education and brokerage are important devices to overcome network truncation in bureaucracy and stimulate cooperation between non-trusting individuals. ${ }^{412}$ In order to find sufficient members for the network, initial trust can be build on common factors like origin or religion, although their role is transitory. While some factors like race, sex and family background are given, others can be altered such as reputation, education, and religious beliefs. The value of these indicators declines, to be eventually replaced by the transactions themselves.

The cumulative inefficiency of informal services is the result of deficiencies in the extent and intensity of the network. Network failure depends on the riskiness of an inefficient supply of informal services, which, in turn, depends on the cost of

408. The formal structure stays important because it is a significant determinant of the cost of accumulating and maintaining networks.

409. Breton and Wintrobe (1982), Logic of Bureaucratic Conduct, p. 38.

410. ibidem, p. 88 .

411. ibidem, p. 84 .

412. The cost of network. truncation, namely the loss of informal services, has to be weighted against the costs of rent-seeking by interest groups, that may arise from a common educational background or religion. 
monitoring. ${ }^{41}$ So, bureaucratic loss of control can arise from formal operations and from network failure. However, there are ways of bypassing formal routines and inefficient informal sources and thus increasing the speed and quality of operations. One technique by which the head of the bureau can maintain control is to obtain external information about what the lower-ranking agents of the organization are doing. Also the costs of informal services can be reduced, if there exists competition for network membership. Competition for positions in networks eliminates the rents due to selective behavior, but it does not eliminate selective behavior. ${ }^{414}$ When poor informal services are discovered, exclusion from the network is a likely penalty, decreasing the former member's power and influence.

Hypothesis 14: Althoff's network improved the performance of the bureaucratic and academic system.

Althoff was a legendary master in building an extensive informal network in academic and bureaucratic, as well as financial and political circles. The informal network was strictly confidential. It provided Althoff discretionary financial means, but most important qualitative and accurate information about scholarly performance. Donations from private sponsors were often rewarded with a distinguished mark of honor, for which Althoff had to activate other network contacts since he had not the authority to award them. Operating the academic network came at low cost because the scientific community is basically an existing, informal social network in which scholars freely participate and which generates and stores valuable information about scholarly performance. The network played an important role in reducing the monitoring costs of the employing authority, i.e. the Prussian state. ${ }^{415}$ Exclusion. from the Althoff network was a likely penalty for giving inaccurate information. It could have career consequences as well.

The threat of network truncation was reduced by the existence of schools from which all or most senior bureaucrats were recruited. The modern Prussian universities of Königsberg, Halle and Berlin were important schools for high-ranked civil servants. Brokers further reduced a permanent form of truncation. Schmoller, for example, was the intermediary between Althoff and Johannes von Miquel, the Minister of Finance.

Proposition 38: Continuity is likely to improve selective bureaucratic behavior.

Bureaucrats render more and better informal services, when there is a higher degree of continuity in the formal structure. The problem of efficient behavior and cooperation by bureaucrats can be analyzed using standard game theory like the prisoner's dilemma. In the game, two parties gain from cooperation, but each can gain even more if he cheats while the other cooperates. Despite the mutual benefits of

413. The desired amount of monitoring is the level that equals the marginal benefits of reducing inefficient behavior with the marginal opportunity cost of the resources devoted to monitoring.

414. This accounts for the emphasis by Breton and Wintrobe on the simultaneous use of direct. formal monitoring by sponsors to eliminate inefficient behavior.

415. Cfr. proposition 7 . 
cooperation, selective inefficient behavior is the dominant strategy if the game is played only once. However, if the game is repeated a large number of times, each participant has an incentive to cooperate. If he does not cooperate, the other can retaliate on the next round. This seems to offer a way out of the prisoner's dilemma. The argument of repeated interaction and a long time horizon is often used to explain why fraud is not a more prevailing feature of economic behavior. In situations of continued interaction, individuals typically cooperate with each other. ${ }^{416}$ The amount of trust is likely to be an increasing function of the time that the individual, in whom trust has accumulated, stays in the same position.

Althoff worked in the Ministry of Culture as a leading bureaucrat for a quarter of a century. ${ }^{417}$ This enabled him to set up a very large, well functioning informal network.

\subsection{Public Entrepreneurship}

The most typical feature of the classical model of bureaucracy is the hierarchical structure, in which rules specify official duties and limit the authority to give commands. Appointment procedures often even specify the selection of bureaucrats, who advance through the hierarchy by meeting objective standards for promotion. Compensation is related to factors such as hierarchical position and seniority. Such an organization form seems to leave little room for entrepreneurship. Peirce and Krueger have noted that

"unless a major new idea comes from the top, it is difficult to see how it can enter the hierarchy at all. $=118$

The public entrepreneur is bound by the same bureaucratic rules and procedures and has to eliminate hierarchical as well as budgetary constraints to innovate the public sector. If successful, the elimination is the expression of an initial act of entrepreneurship.

Although there exisı several theories about the risk-bearing properties of the entrepreneur, ${ }^{419}$ and his alertness to unnoticed opportunities, ${ }^{400}$ there are few formal models of entrepreneurial behavior, probably as a result of the very nature of entre-

416. At the end of the repeated game, the rational strategy for both players is non-cooperation. If each participant expects the other to cheat in the last round, non-cooperation is also the dominant strategy in the next last game. Non-cooperation then remains the prevailing strategy throughout the game.

417. See observation 1 .

418. William S. Peirce and Peter Krueger (1989), Entrepreneurship in a Bureaucracy, Paper Althoff Conference, Heilbronn, p. 9.

419. See: Frank Knight (1921, repr. 1971), Rissk. Unçertainty and Profit, Univ. of Chicago Press, Chicago; Ludwig von Mises (1949), Human Action, Yale Univ. Press, New Haven.

420. See: Israel M. Kirzner (1973), Competition and Entrepreneurship, Univ. of Chicago Press, Chicago; Harvey Leibenstein (1968), Entrepreneurship and Development, American Economic Review 58, pp. $72-83$. 
preneurship, which is characterized by spontaneous initiative. ${ }^{e 1}$ Entrepreneurial innovation has been defined as the implementation of changes in products and in organizational and technical production methods and the opening of new markets. 2 Innovations in the public sector have not often been modeled as an entrepreneurial process, ${ }^{\infty 3}$ although new programs and policies can be readily understood as innovations in the Schumpeterian sense. The allocation of resources to the implementation of a new public policy is an act of innovation and entrepreneurship.

Proposition 39: A public entrepreneur has to acquire a sufficient degree of autonomy.

Following Frey, ${ }^{04}$ it is hard to impute motives to the public entrepreneur. When a bureaucrat is dedicated to a new policy or program, he may well see the innovation as his personal goal. First, however, the public entrepreneur must obtain some degree of autonomy, as well as resources. Peirce and Krueger have distinguished several key problems for the public entrepreneur: (1) moving up the hierarchy to a position, sufficiently high to launch new projects, attaining enough autonomy, while maintaining managerial control of agents, (2) obtaining control over sufficient resources, while finding resources for eventual growth. (3) establishing a network of relations outside the department in order to obtain the support necessary to realize new programs. 23

The entrepreneur has to occupy a formal position in the hierarchy with enough authority to get a minimal amount of cooperation from the bureau's staff. But instead of considering the limits of the organization, the successful entrepreneur generally bypasses hierarchical constraints. Entrepreneurial activities in public agencies differ from the private sector in the way money is raised. The bureaucratic finance market is often internal and hierarchically organized. Peirce and Krueger have argued that

"in a constitutional framework dominated by a strong monarchical power, high bureaucrats had to replace politicians more frequently than in parliamentary systems". 426

Even if political instability implies that decision-making tends to fall into the hands of the bureaucracy, the public entrepreneur's problem stays the same, to launch innovations within an organization that is structured to achieve stability, consistency and predictability. He must arrange to obtain autonomy and to acquire resources.

Proposition 40: Entrepreneurial capacity is determined by the extent and the intensity of the networks that are set up by the entrepreneur.

421. W.J. Baumol (1968), "Entrepreneurship in Economic Theory", American Economic Review 58, pp. 6471 .

422. Joseph A. Schumpeter (1934), The Theory of Economic Development, Harvard University. Press, Cambridge Mass.. This author makes a clear distinction between the moment of invention and the entrepreneurial moment of making productive use of it.

423. Major innovations are not hard to list though: the social security system, cost-benefit analysis, science policy, etc.

424. Bruno Frey (1986), Human Behavior, p. 140.

425. William Peirce and Peter Krueger (1989), Entrepreneurship in a Bureaucracy.

426. ibidem, p. 32. 
Casson's entrepreneur is a person who specializes in taking judgemental decisions about the allocation of scarce resources.

"A judgemental decision is one where different individuals, sharing the same objectives and acting under similar circumstances, would make different decisions $^{-127}$,

because there exists no objective decision rule or because individuals have different access to information and different processing abilities. Casson acknowledges the difficulty for an entrepreneur to raise funds in order to exploit his better judgement, which is based on a comparative information advantage. The sponsor has to have confidence in the entrepreneur's judgement and conduct. This leads to the questions raised earlier about reputation and the accumulation of trust. Breton and Wintrobe have defined entrepreneurial capacity as the capacity to accumulate trust and build networks. ${ }^{\text {es }}$

Hypothesis 15: Althoff was a public entrepreneur.

Althoff was the driving force behind the implementation of various academic innovations. He could rely on hard-working staff members, who prepared his measures. Although the term "Althoff system" probably gives too much credit to one man, it was Aithoff who made the ultimate decision to implement a new policy. ${ }^{429}$ This accounts for the fact that the entrepreneur is essentially an innovator, not an inventor. The degree of public entrepreneurship is also affected by the bureaucrats who have to carry out these new measures. Althoff was one of the leading bureaucrats in the Prussian Ministry of Culture, whose authority was reinforced by the multi-source financing system, his professionalism and the support from the Emperor. He also maintained a manageable span of control within his own department. Althoff operated a large network for financing and information purposes.

Althoff succeeded in building a flexible, innovative bureaucracy, although principles of bureaucracy often clashed with the traditional rights and liberties of the old universities. To the extent that some negative comments. on Althoff are justified, they may be related to the inconsistency between the routines of bureaucracy and the ambitions of the entrepreneur. However, Althoff, who was a pragmatic manager, did not abolish the vital elements in scholarly self-management. While he took many measures to create a modern academic framework, he never took action to interfere in the creative process of scholarly teaching and research.

427. Mark Casson (1982), The Entrepreneur, Martin Robertson, Oxford, p. 24.

428. Breton and Wintrobe (1982), Logic of Bureaucraric Conduct, p. 108.

429. See observation 6 . 


\section{Conclusions}

\subsection{The Althofr System}

Conclusion 1: The international recognition of German science and. scholarship in the Althoff era reflected its academic performance.

Con. 2: The Althoff system improved the performance of the German academic system.

\subsection{Economics of Science and Scholarship}

\subsubsection{Science Policy}

Con. 3: Policy measures that aim at keeping the scientific community open are likely to improve academic performance.

Con. 4: Policy measures that aim at enhancing the dissemination and verification of academic output are likely to improve academic performance.

Con. 5: Policy measures can improve the quality of academic decisions, hence academic performance.

Con. 6: Academic statistics have incentive value for scholarly performance, but should not be used as policy targets.

\subsubsection{Economic Theory}

Con. 7: The economic theory of science and scholarship demonstrates that institutional conditions are an important determinant of academic performance.

Con. 8: The economic theory of science and scholarship points out how the institutional conditions in the academic system affect scholarly performance. 


\section{Conclusions}

How effective was the "Althoff system" in improving the academic performance of the scholars it employed ? Which role is there for politicians and administrators of science? How effective is the economics of science in helping to answer these questions ? In this final chapter, an evaluation is made of Althoff's science policy and the economic analysis of science and scholarship, which was used and developed in this study. An attempt is also made to point out some relevant principles of science policy.

\subsection{The Althoff System}

Althoff's science policy contained many innovations. A major achievement was the establishment of independent research institutes that became particularly successful for research in the natural and medical sciences. ${ }^{40}$ They freed brilliant scholars from their teaching duties at the university. The expensive institutes were closely linked to the multi-source financing system, that tried to secure the financial basis for long-term. research projects. ${ }^{41}$ The excellent research facilities at these institutes attracted many scholars to Prussia and were also part of Althoff's differentiated and performance-based compensation system. ${ }^{432}$

Undisputed was the expansion and reorganization of the traditional universities, the medical sector, the seminar system, the library system and the start of an international science policy. ${ }^{43}$ The latter took its most visible expression in the international professorial exchanges. Independent research institutes found their educational counterpart in the establishment of seminars.

Althoff reorganized the Prussian academic system to solve the problems of the Humboldtian university system and to gain international recognition for Prussian and German science and scholarship. ${ }^{434}$ These goals were achieved by a mixture of public and private financing and implemented through a carefully organized network of confidential relationships. The central administration of the universities implied a loss of the independence of faculties as well as of individuals. They both became dependent upon a bureaucracy, whose internal workings they could not always understand. The Althoff system was directed by an autocratic, yet devoted,

430. See observarion 16.

431. See observation 32 .

432. See observations $20,21,22$ and 29.

433. See observations $14,15,17,18$ and 23.

434. See observations 4 and 12 . 
bureaucrat, whose policies were intended to keep a liberal and competitive climate at Prussian universities. ${ }^{435}$ A policy of equal opportunities opened the universities to minorities previously excluded. Althoff's role in the protection of minorities and academic freedom at universities is still widely acknowledged. He also looked upon universities and academic institutes as parts of a large academic system and started its rationalization. The process involved the simplification of some procedures while breaking up traditional structures. Althoff insisted on common rules, procedures and requirements, cataloguing systems and statistical procedures in order to facilitate contacts between various institutions.

Conclusion 1: The international recognition of German science and scholarship in the Althoff era reflected its academic performance.

At the turn of the century, Germany was a leading academic nation. Although there is no satisfactory way to quantify this observation, historians of science basically agree about the existence of scientific centers shifting from Italy to England in the middle of the seventeenth century to France during the first half of the nineteenth century and then to Germany from the middle of the nineteenth century. Germany retained its leading role until the 1930 s when the United States took over this position. ${ }^{436}$ While not precisely measurable, the interest and respect of foreign administrators, scholars and students for the Prussian system can be observed to reflect this international recognition. Many countries turned to the Prussian system as the ideal type to model their own academic system. Although severe criticism was passed on some methods, the scientific performance of the Althoff system was beyond dispute. The success of Prussia's science policy was recognized by scholars working in the system and those observing it from outside.

"Many of the most striking American intellectual and organizational innovations were either inspired by or directly adapted from German models, for German leadership in academic science and scholarship was widely acknowledged. ${ }^{437}$

"The pursuit of research was recognized as an important professional activity within both the U.S. industry and higher education only in the late nineteenth century, and research in both venues was influenced by the example and by the. competitive pressure of German industry and academia.

435. See observation 2 and 30 .

436. Joseph Ben-David (1971), Scientist's Role in Sociery, pp. 15 and 186.

437. A.W. Coats (1987), The Instifutionalizarion of Political Economy in European, American and Japanese Universities, Paper Fifth HESA (History of Economics Society of Australia) Conference, p. 21.

438. David C. Mowery (1990), "The Development of Industrial Research in U.S. Manufacturing", American Economic Review, Papers \& Proceedings, p. 347. 
"It was this double allegiance to higher learning - generation of new knowledge as well as dissemination of received knowledge - that in the late nineteenth century attracted the attention and admiration on the part of American academics. [..] German universities were the model for the 'research universities' in the United States.

German science and scholarship were internationally respected. The German universities had a great appeal to large numbers of foreign students. In the first decade of the twentieth century, foreigners represented. $7.5 \%$ of the male student population in Germany, ${ }^{400}$ which made it the nation with the largest share of foreign students. ${ }^{41}$ To inform all these students about the possibilities of higher education in Prussia, the Ministry of Culture set up an Academic Information Bureau in Berlin. ${ }^{42}$ International recognition also came from the research front. A large number of Nobel Prize winners worked at German academic institutes. ${ }^{\text {*3 }}$ International recognition also resulted in official exchange professorships. American academics knew the value of the German university system, because many of them had been educated there. ${ }^{44}$ At the turn of the century, German scholarship could claim international recognition, which had been a primary goal of the Althoff system. ${ }^{\text {as }}$ The Althoff system achieved this international recognition by means of an exemplary scientific performance.

Scholars working at Prussian institutes made some pathbreaking scientific discoveries. The Prussian administration fostered the development of medical science. In the Althoff era, it opened eight hospitals for ophtalmology " nine institutes for dentistry, seven psychiatric clinics and sixty-two new clinical buildings connected to universities. Several pediatric clinics and academic institutes for hygiene were built in order to battle tuberculosis and infant mortality. ${ }^{46}$. The reorganization of the Charite-Hospital meant a major step forward in the public health situation of the

439. Fritz. Machlup (1982), Knowledge: Its Creation, Distribution and Economic Significance (vol. 2: The Branches of Learning), Princeton University Press, Princeton, p. 141.

440. Bernhard yom Brocke (1981a), Preupische Bildungspolitik, p. 743.

441. Wendel reports that in 1904 there were more Russian than German students, who studied mediçine in Berlin. See: Günther Wendel (1991), Aktivitären Althoffs, p. 126.

442. The Academic Information Bureau was directed by Wilhelm Paszkowski (1867-1918), who had been a librarian and lecturer of German for foreigners at the University of Berlin. To emphasize the importance of the position, Althoff awarded Paszkowski a professorial title.

443. Nineteen of the fifty-five Nobel Prize winners in the natural sciences before 1918 worked in Germany. Thirteen were active in Prussia. Most famous are Emil Behring (Medicine, 1901), Jacobus van 't Hoff (Chemistry, 1901), Emil Fischer (Chemistry, 1902), Robert Koch (Medicine, 1905), Philipp Lenard (Physics, 1905), Paul Ehrlich (Medecine, 1908) and Albrecht Kossel (Medicine, 1910). For many of them, Althoff created career opportunities and research facilities.

444. Three of the finest American universities (Harvard, Columbia and Chicago) set up exchange programs of professors. Their presidents (Charles W. Eliot (1834-1926) of Harvard (18691909), Nicholas M. Butler (1862-1947) of Columbia (1902-1945) and William R. Harper (1856-1906) of Chicago (1891-1906) had all studied in Germany.

445. See observation 4.

446. Althoff presided over the International Tuberculosis Society, which he had founded in 1902. 
Berlin region. ${ }^{47}$ To update the knowledge of practicing physicians, local academies for practical medicine were created. Three German Nobel Prize winners for Medicine personally acknowledged Althoff's support in providing them with the means to pursue their revolutionary research. ${ }^{406}$

Chemistry was a booming industry and scientific discipline. A lot of research was carried out in the research and development centers of chemical corporations, while the state laboratories specialized in qualitative fundamental research. Famous scholars worked at the state institutes, among whom Adolf von Baeyer, Emil Fischer, Jacobus van't Hoff, August Hofmann, Victor Meyer and Walther Nernst. Since most university chairs in chemistry had been occupied by scholars in the organic tradition, organic chemistry had developed rapidly. However, new disciplines such as inorganic chemistry, physical chemistry and electro-chemistry were also emerging. Althoff created a suitable infrastructure for these disciplines as well. ${ }^{499} \mathrm{He}$ was also personally interested in issues of biology. ${ }^{450}$ His appointment of professor Adolf Engler added to traditional taxonomy the study of biotopes. ${ }^{45 t}$ Biochemistry and evolutionary physiology were also new and promising fields in which German scholars made considerable progress. ${ }^{452}$ Technological progress made possible the

447. The project was financed by selling the Botanic Garden in Schöneberg and moving it also to Dahlem.

448. Emil Behring, who had been considered somewhat as an academic outsider, received the Nobel Prize in 1901 for the development of a diphteria serum. Althoff had appointed Behring at the University of Marburg in 1895 in spite of a threefold refusal by the medical faculty. Behring was given an extraordinary professorship without teaching duties to pursue research in his laboratory, that was financed largely by the Hoechst corporation. Althoff also supported Robert Koch, who became full professor in Berlin, member of the Academy of Science and director of the Institute for Infectious Diseases. Koch, who received the Nobel Prize in 1905, gratefully acknowledged Althoff's role for his career. Paul Ehrlich, who discovered the salvarsan cure for human syphilis and got the Nobel Prize in 1908, was liberated by Althoff from his oppressive superiors, professors Rudolf Virchow (1821-1902) and Ernst von Bergmann (18361907). Ehrlich was given the opportunity to have his own research institute in Frankfurt.

449. In Gơttingen, the chair for physical chemistry was offered to the brilliant scholar, Walther Nernst (1864-1941). Nernst became full professor in 1894. In 1899, Althoff created a chair for inorganic chemistry, which was filled by Gustav Tamman (1861-1938). With the help of the German Electro-Chemical Society. Althoff also financed an ordinary professorship of electrochemistry at the University of Göttingen.

450. Althoff was one of the first to promote the protection of the environment. At the request of the Prussian. Ministry of Culture, Hugo Conwentz (1855-1922), the director of the Westprussian Province Museum in Danzig, wrote a pathbreaking document (Die Gefahrdung der Narurdenkmaler und Vorschlage zu ihrer Erhalrung). On December 12, 1898, the Prussian Ministry of Culture even organized a conference about environmental protection. Representatives of other ministeries attended.

451. Engler received the chair of systematic botanics and became director of the Botanic Garden in 1889.

452. In spite of the criticism from Wilhelm Waldeyer (1836-1921) and Oscar Hertwig. Althoff supported the development of evolutionary physiology by scholars like Eduard Pflügler (18291910). Wilhelm Roux (1850-1924), the pioneer in evolutionary physiology, was appointed as extraordinary professor in 1884. Four years later, Roux became director of the Institute for Evolutionary History and Mechanics at the University of Breslau. In a letter of August 2, 
emancipation of the technical sciences and colleges. While the Göttingen. Association set up institutes to do research on technical problems like aviation, hydrodynamics, aerodynamics and theoretical physics became the cornerstone of the Berlin university with distinguished scholars like Max Planck, and later Albert Einstein.

The only discipline in which the Althoff system was less successful, was philosophy. The reason was that the characteristic Althoff network was not so well-balanced in this field. ${ }^{45}$ The large majority of informants were scholars of the New Kantian doctrine, which had risen to a kind of Prussian state philosophy. Althoff's confidential agents promoted, of course, this line of thought, which came at the disadvantage to Hegelianism and Herbertianism. It led to the dominance of the Marburger school of Kantianism, leaving little room for alternative views. Nevertheless, Althoff supported the emancipation of new disciplines emerging from the traditional field of philosophy such as pedagogics, psychology and sociology. He promoted their scientific development by setting up psychological institutes and pedagogical seminars.

Although some academic problems, like the legal and financial position of the private lecturers, were not resolved, most of the grievances of professors revolved around lost appointments and salary questions and did not address the innovations that comprised the Althoff system. Criticism was often directed at the fact that Althoff was not in the formal position to shape Prussian science policy. ${ }^{454}$

Since it takes an Althoff to run an Althoff system, Naumann wrote:

"Solange ein Mann wie Althoff an der Spitze steht, laßt sich ein 'System Althoff' entragen, so wie ja auch der aufgeklärte Absolutismus' seine guten Seiten hatte. Gerät aber große Macht in kleine Hānde, so wird kleinlicher Mißbrauch der Gewalt die bedauerliche Folgeerscheinung sein. "nss

The Weber-Althoff controversy, which was also mentioned earlier, is probably the best-known criticism of the Althoff system. ${ }^{450}$ In 1911, Max Weber (1864-1920) delivered a speech in Dresden in which he admitted that Althoff had taken a much broader point-of-view than the faculties to promote scientific development. He added that Althoff's structural measures and strong administration had pushed Prussian

452....

1907, Roux thanked Althoff for his support and the advancement of the discipline, which, after years of ignorance and struggle, was finally recognized by the scientific community. Althoff had also set up a research institute for his opponent, Oskar Hertwig.

453. Ulrich Sieg (1991), "Im Zeichen der Beharrung. Althoffs Wissenschaftspolitik und die deutsche Universitătsphilosophie", in: Bernhard vom Brocke, Hrsg., Wissenschaftsgeschichte und Wissenschaftpolitik im Industriezeiralter, Verlag August Lax, Hildesheim, pp. 287-306.

454. See observation 7.

455. Quoted in: Bernhard vom Brocke (1980), Hochschul- und Wissenschaftspolitik, p. 109.

456. Max Weber (1973), translated by Edward Shils, "The Power of the State and the Dignity of the Academic Calling in Imperial Germany: The Writings of Max Weber on University Problems", Minerva 11, no. 4, pp. 571-632. See also: Peter Senn (1989), Where is Althoff?. 66 pp., and Helmut Spinner (1991), "Das 'System Althoff' und Max Webers Kritik", in: Bernhard vom Brocke, (Hrsg.), Wissenschaftsgeschichte und' Wissenschaftspolitik im. Industriezeitalter, Verlag August Lax, Hildesheim, pp. 503-563. 
universities forward and that nepotism had not existed in the Althoff era. However, Weber was very critical about the confidential consultation of academic agents and the process of bureaucratization. Ironically, bureaucratization was understood by Althoff in the Weberian sense of rationalization. Weber became more and more critical, however, about the prolonged existence of a system that no longer demonstrated the exceptional performance of the time when it was run by its founder. Senn has argued that

"even if Weber was right, it would be only a footnote about Althoff's methods. For the historian of science what will count are the results. The product, not the process, is the important thing, unless it can be shown that somehow the process did influence the product - which Weber did not do. ${ }^{\text {w157 }}$

Moreover, in spite of the authority which he had earned, Althoff always had to seriously take into account the reasoned demands from the universities. After Althoff's death, the system could no longer uphold its performance because the informal scientific-administrative network became more and more truncated.

Conclusion 2: The Althoff system improved the performance of the German academic system.

The Althoff system is the German term to describe the reform and expansion of the Prussian academic system, which, at the turn of the century, spanned a period of twenty-five years and pushed the development of science and scholarship. Althoughi Althoff did not produce a single plan to show a system, ${ }^{458}$ he took a number of coherent measures, which enhanced the productivity of the academic system. This study has tried to show how changes in the academic organization affected the performance of German scholars in the Althoff era. ${ }^{439}$ From the economic analysis in this study, it follows that the Althoff reforms were very helpful in upgrading scholarly performance. The gradual reform of the academic system by Althoff had the following characteristics.

Since the scientific community constantly evaluates academic output and gives credit to productive scholars, it was rational to take the reputation of German science and scholarship as decided by the world community of scholars as a criterion of academic performance. ${ }^{400}$ Althoff stimulated academic productivity by taking measures that kept the scientific community open and improved the dissemination of knowledge.

"Die Akten/Berufungsangelegenheiten zeigen, welchen Wert auf das Nebeneinanderbestehen vieler verschiedener wissenschafilicher Richtungen [..] gelegt wurde. ${ }^{\text {*to }}$

457. Peter Senn (1989), Where is Althoff?, p. 21.

458. Unlike other prominent German administrators of science like Wilhelm von Humboldt (17671835) and Carl Heinrich Becker (1876-1933).

459. Atthough it is hard to value the importance of those who facilitate or make possible the work of others, the efficient organization and administration of institutions to produce knowledge enhanced scholarly performance. From this, it follows that Althoff deserves some of the credit for e.g. Ehrlich's or Schmoller's work.

460. See observation 4 .

461. Renata Tobies (1991), Wissenschaftliche Schwerpunktbildung, p. 97. 
The bundle of measures enhanced the workings of the scientific community, hence better guaranteed the quality and accuracy of academic output. Althoff processed information about scholarly performance, generated by a network in the scientific community, to select and attract the most suitable scholars to Prussian universities. He could assume the appointment responsibility because he had established a comparative information advantage over the university community, that remained rationally ignorant. Althoff was better informed about scholarly performance via his contacts in the scientific community of a certain discipline. In turn, it allowed the scientific community to play a more formal auditing and disciplinary role. ${ }^{\text {to }}$. Althoff not only used it as a monitoring technique, but also as an incentive instrument to overcome the principal-agent. problems in the academic system. ${ }^{\text {ay }}$ Indeed, the Althoff system enhanced academic performance, not only by appointing the most productive scholars, but also by the incentive value of the screening method.

Faculty management is often associated with reduced academic output, because control is less concentrated. ${ }^{4 / 4}$ Transaction cost analysis demonstrated that centralization of decision rights can be efficient. The Prussian bureaucratic academic organization lowered the monitoring costs of academic production, and at the same time internalized some of the external benefits. ${ }^{\text {as }}$. Althoff saved on monitoring costs by using the free auditing results of the scientific community. To process this type of information and to capture the academic externalities required some degree of centralization. The transaction cost rationale holds for the independent research. institutes as well. Because the monitoring costs of true talents are low, they could operate outside the hierarchical organization in independent research institutes.

The property rights theory of the firm affirms that centralization of rights improves the quality of decision-making. The Prussian bureaucracy or the institute directors took over managerial responsibilities of faculty in matters like appointments, promotion, tenure, etc. The Prussian state and the institute directors had an incentive to be good managers, because they were the central monitoring party that could capture the reputational or financial residual. Finally, Althoff introduced a motivating and performance-based compensation system. Since the residual claimants determined. compensation, they had a clear incentive to be as accurate as posșible in the assessment of scholarly productivity. In accordance with human capital and implicit contract theory, the Althoff system paid low starting salaries for junior scientists, but huge wages for top scholars.

However, hierarchical organizations suffer from control losses that are created by information distortions and lead to inefficient results. The principal-agent problem that arose from the attenuation of control was solved by the comparative information

462. Due to the use of scientific community, the Althoff system could reduce the disadvantages associated with academic tenure. See hypothesis 10 .

463. Following the exchange theory of bureaucracy, the informal networks determine the efficiency of bureaucratic organizations. See also hypothesis 14 .

464. Robert E. McCormick and Roger E. Meiners (1988), Universiry Governance, pp. 423-442.

465. See hypotheses 2 and 3. 
advantage and the authority of Althoff. In a relatively small bureaucracy, Althoff maintained a manageable span of control. Although he was never in the formal position to shape Prussian science policy, Althoff became known

"not only as the most enlightened, but also the most dictatorial Minister of

Education (sic), Prissia had ever had. "sob

The public choice approach to bureaucratic behavior revealed the basis for Althoff's authority , which allowed him to operate beyond the limits of his formal responsibilities:467 lifting of some of the bureaucratic constraints such as sponsor reviewing, professionalism and continuity. Along with a manageable span of control, Althoff's entrepreneurship is likely to have improved the efficiency of the academic system as well.

The institutional innovations introduced an element of competition in the Prussian academic system. New chairs, new institutes and new universities undermined the monopoly position of the traditional universities. This created new opportunities for individual scholars to leave the university, which exerted pressure on the academic authorities to reward them according to performance. The Prussian academic administration also worked efficiently, because it had reliable information sources and a correct evaluation method. However, this does not imply that different organizational answers may not reduce transaction costs, capture external benefits and encourage competition in the academic production process as well.

From an economic point of view, the Althoff system can be defined as a systematic policy to institutionalize the incentives and monitoring procedures of the scientific community, which involve the careful evaluation of scholarly output, and to enhance academic decision-making methods by distributing decision rights to the residual claimants of academic production. Althoff's science policy was so entrepreneurial that it created room for competition in the academic system. It has also been desribed as

"a concerted policy to stimulate work in academic institutions. By building on the existing institutional structures, new organizational designs were established along with a common infrastructure for academic research and instruction. ${ }^{4688}$

The Althoff system was a balanced combination of central administration and individual freedom.

"Grob könnte man die von [..] Friedrich Althoff praktizierte Ansicht so formulieren, daß $\mathrm{\beta}$ es in der Wissenschaft weniger darauf ankomme, Personen unter institutionell vorgegebene Rollen zu subsumieren, und mehr darauf, für Persönlichkeiten möglichst weitreichende Freiräume $z u$ aktiven Selbstgestaltung günstiger institutioneller Bedingungen zu ermöglichen, "469

By taking the view of a wider academic system, Althoff was in a position to interject competition from other scholars when the vested interests of one particular academic institution tended to promote scholarly qualities other than academic proficiency.

466. William H. Dawson (1919), The German Empire 1867-1914 and the Unity Movement, Macmillan, New York, vol 2, p. 411.

467. See observation 7.

468. Jürgen G. Backhaus (1990), Regulation, p. 30.

469. Hubert Laitko (1989), Humboldt und Althoff, p. 5 


\subsection{Economics of Science and Scholarship}

In this study, an attempt has been made to find out how the institutional environment affects scholarly behavior and to determine, if possible, the conditions for productive academic activity. The study of the Althoff system has made it clear that institutional changes can drastically improve academic productivity. The economic theory, developed in this book, which draws on the new institutional economics, claims to add more to the theory and practice of science policy than repeating the rules of good management. It is capable of assessing the effect of institutional changes on academic performance.

Since it is hard to assess: the value of academic production and measure the advancement of science by means, of quantitative indicators alone, efficiency standards are hard to establish. ${ }^{40}$ There is simply no way of determining whether any given amount of resources is the correct amount to invest in the academic system, nor is there a set. of administrative rules that would be capable of assuring efficient outcomes. Nevertheless, economic analysis can be helpful in finding ways to stimulate academic performance. In that case, there is also room for an active science policy, that takes measures to improve the performance of the academic system. Nevertheless, science policy should never try to plan research too precisely, because research is, by definition, a creative search for the unknown.

\subsubsection{Science Policy}

The auditing and disciplinary procedures of the scientific community exert such pressure on academic scholars that they bring about a high level of quality and accuracy in academic output. These procedures are based on the continuing verification and dissemination of academic output. Improving these functions, which require an open community, is likely to enhance the quality of the academic output as well.

Conclusion 3: Policy measures that aim at keeping the scientific community open are likely to improve academic performance.

The scientific community functions well only if newcomers and new ideas are allowed to challenge the existing body of knowledge. Measures can be taken that increase the heterogeneity of the academic population, for example, by allowing academic newcomers with alternative views. However, the entry to the academic profession is sometimes refused for reasons irrelevant to the quality of production. There often exists discrimination on the ground of criteria irrelevant for academic performance (religion, race, political conviction, sex). The academic system should be kept open to outsiders, who may follow unconventional research procedures that may revolutionize science. 
Although there is a role for amateurism in science, science administration can actively improve the alertness of the scientific community to new and promising discoveries by planting these scholars with alternative ideas in the academic system. Outsiders not only bring new human capital to the scientific community, they often open new financial sources for the development of knowledge as well. ${ }^{471}$ Academic inbreeding can have stifling effects on scientific progress. Faculty homogeneity can be easily prevented e.g. by facilitating academic mobility or by insisting on open vacancies. When scholars refuse to accept new methods or theorems, competitive pressures can. create the opportunities for alternative views, that are vital for scientific progress.

Academic expansion with the creation of new chairs in new and existing disciplines, institutional reform and international cultural exchanges are three effective means to stimulate competition among scholars and to open the scientific community. While growth and reform of the university system create more breathing room for new scholars, exchange programs are favorable for an open climate. The principle of academic freedom has its greatest merit as a guarantee for a diversity of views. Since the marginal return on increasing faculty is likely to decline, it is wise to keep scholars somewhat dispersed in their interests. Concentration is likely to lead to a. marginal increase in the rate of discoveries in some fields, but may greatly reduce the rate in the fields from which scholars have been drawn. ${ }^{472}$

Conclusion 4: Policy measures that aim at enhancing the dissemination and verification of academic output are likely to improve academic performance.

The dissemination of scientific knowledge is essential for the verification process. Well-organized libraries may, therefore, improve academic performance by lowering the search costs of scholars and by facilitating the dissemination of scientific knowledge. Search costs can decline further by establishing good cataloguing systems. A system of public lectures and printed papers and dissertations is likely to restrict the possibility that knowledge is kept inside an academic group so that no further use can be made of it, or that it is not produced at all. ${ }^{473}$

Another method is to stimulate applied research, because when research is tied to its applications, it creates incentives for accuracy. ${ }^{474}$ Applied researchers tend to be less interested in the intellectual elegance of various theories, but do want their applications to work. Since it is impossible to predict which use they make of any given theory, these scholars are the strongest possible check on the accuracy of the

471. While the appointment of Catholics and Jews to academic positions opened up a new labor market and created the possibility of making outstanding appointments, it also opened additional financial resources, which facilitated the expansion and reform of the academic system.

472. Gordon Tullock (1966), Organization of Inquiry, p. 129.

473. The requirement to print dissertations, urged by Althoff, was also meant to protect the brand name of the German doctor's title.

474. In this respect, Althoff upgraded the technical colleges, promoted the foundation of business schools, set up numerous research. centers and stimulated the applied fields in the medical sciences (e.g. hygiene). 
work of the pure scientists. The absence of a community of such critics may greatly retard the development of a discipline. The scientific community itself is also subject to social pressure, which can create an unfavorable atmosphere for research. There lies a task for the science administrators to help and create a more favorable environment for research. ${ }^{475}$

The quality of the review and editorial activity has an impact on both the dissemination and verification of academic work. Improvements in these areas can be made as well. The problem is largely one of incentives. A higher pay and improved prestige for these strategic members of the scientific community is likely to attract into editing scholars, who may have lost some of their creativity, but who are still able to recognize good new research.

The decoupling of research and teaching can relieve leading scholars of repetitive duties and allows them to use their resources most effectively. It can be done by means of research directorships or professorships with primary teaching responsibilities in order to support selected chairholders. However, the separation can lead to a slow-down in the dissemination of new knowledge as well, which, in accordance with conclusion 4 , is likely to lead to less scientific progress. ${ }^{476}$ To satisfy the need for teachers who are involved in research at the leading edge, students could participate in the research program of a top scholar, who could still carry out his research program, while students would learn to do research without formal instruction. Teaching at the advanced and doctoral level mostly requires the same ability as research.

Conclusion 5: Policy measures can improve the quality of academic decisions, hence academic performance.

A science administration can reduce the burden of leading scholars, whose time and energy are taken up otherwise with administrative activities and management tasks. Moreover, by taking over management tasks of the faculty, opportunities for rentseeking are reduced. To maintain a high quality of decision-making, it makes sense to attribute academic decision rights to the residual claimants, who have a clear incentive to run their institutes efficiently. ${ }^{477}$ Appointment decisions can be left to the party who can claim the residual and has the best access to the scientific community to assess the scholarly productivity of a candidate. This can be the central administration - as it was in Althoff's case - or the director of a research institute. The residual provides an incentive to make sure that appointment and promotion procedures involve more than counting the number of articles without making any serious effort to determine how important they are. To attract real scholars.

475. In Prussia, there was a huge demand for trained economists and lawyers to work in the public administration. Social scientists were involved in experimental legislation and in the creation of the social welfare state.

476. See also proposition 24 .

477. In the Althoff system, the academic residual took the form of increased professional recognition or increased revenues from an increasing tax base. 
compensation can be offered in terms of research facilities, which emphasize the scholar's direct interest in research. ${ }^{478}$

Academic administrators have to allocate resources over various scientific projects. Not every administration possesses the academic network of the quality and extent as Althoff's to evaluate a project or the productivity of a scholar. When it has to allocate research grants, it should pay less attention to the nature of the specific project and more to the results achieved by the scholar. If the scientific community functions well, the performance of scholars is reflected by their professional recognition. The administrator should, therefore, make an effort to get an idea about the position of a scholar in the scientific community. Productive researchers should then be given the means to carry out the research program of their own design, under the condition that further funds depend on the results they obtain. In addition to being given research facilities and grants, these scholars could be asked to recommend newcomers for initial positions. Although the evaluation of academic output should be the rule, it makes sense to evaluate input behavior in the case of team production and junior scientists. If the new scholars produced good work, the senior scholars could be asked to suggest some more.

While it can take a decade or more to establish a research program or to build an academic tradition and institutions, they can be destroyed rapidly. An essential part of academic management is therefore to provide a sound and stable financial basis. Althoff's multi-source financing system spread the risks and, at the same time, guaranteed academic independence from specific money providers. Financing of research by private foundations, that are set up by prominent leaders from industry and trade, has the advantage of breathing an entrepreneurial spirit into the academic institutions.

Conclusion 6: Academic statistics have incentive value for scholarly performance, but should not be used as policy targets.

Administrations have to be aware of the problems associated with quantitative indicators to evaluate academic performance. For example, graduation rates do not reflect teaching performance, because examination standards can be relaxed easily to improve these rates. Therefore, academic statistics should not be used as allocation devices for grants. However, when the reputation of a professor is not affected by the number and quality of his students, he has an incentive to take few students with easy subjects, in which he has to invest little time and effort. It takes formal reports with the history of rejection policies and public examinations to assess and improve teaching performance per faculty or per chair. As a method of adjusting the

478. Economic theory suggests that academic compensation is not likely to reflect the marginal revenue product of a scholar. It operates as an incentive for the employed scholar and his colleagues. Whereas patent monopolies and certain tax privileges provide good incentives for applied research, non-specified awards are well-suited for basic research. Compensation should be determined by realized output, with the exception of the junior scholar, whose compensation can only be determined by expected output based on input measures. 
motivation of professors, a system could be set up that makes promotion policies public. A more formal approach to assess academic performance would be to trace the graduation of productive as well as the rejection of unproductive students in the interest of scientific development. Administrations should be aware that their helpful planning instruments have great incentive value for scholars and build signaling pressures. Therefore, they should be performance oriented.

A more general danger of statistics lies in the fact that academic performance is more likely to be lower when some aspects are measured while important aspects are not. Formal auditing upon observable variables with formal policy implications with regard to the availability of funds may cause a misdirecting of efforts toward measured from unmeasured activities. Moreover, the reliance on statistics alone tends to undermine the authority of the monitor. Although the qualitative and public nature of academic output limits the effectiveness of such techniques in the academic system, the formal auditing procedures exert a certain pressure upon the individual scholar to perform. The practices of citation and publication counts for example are means to control and ensure some minimum level of activity, but do not measure the quality and value of academic output. Using them as the sole determinants of decisionmaking would lead to serious misallocations.

\subsubsection{Economic Theory}

Conclusion 7: The economic. theory of science and scholarship demonstrates that institutional conditions are an important determinant of academic performance.

Transaction cost analysis pointed out that academic knowledge production can be organized only under a specific governance structure to protect the scholars and the employing authorities and to save on transaction costs. Especially, the monitoring of academic production can be very costly. However, academic monitoring cosis can be kept quite low if the monitor succeeds in obtaining the free results of the voluntary auditing of scholarly output, that takes place among the members of the scientific community. Monitoring costs can also be reduced by hiring workers that need not be watched so closely (like pure curiosity scholars). Transaction costs can be further reduced by a standardisation of some procedures, for example by setting up coherent university regulations, and examination requirements. Loyalty and discipline reduce the monitoring costs of production as well. Indeed, shirking problems can be solved by a positive work ethic or social pressure to abstain from shirking. ${ }^{479}$ The problem is also dealt, with by an open scientific community. The community is an informal social organization that coordinates the activities of scholars and allocates scholarly efforts efficiently. While reciprocal monitoring of scholars is a rational and costsaving solution, it implies that there is no immediate role for a central monitor. Yet, a science administrator can make substantial improvements to the academic system and, to a large degree, he can correct scientific community failures. Important is that he

479. Estelle James and Egon Neuberger (1981), " The University Department as a Non-Profit Labor Cooperative", Public Choice 36, pp. 585-312. 
can create an institutional environment which is favorable for productive and creative academic activity.

Conclusion 8: The economic theory of science and scholarship points out how the institutional conditions in the academic system affect scholarly performance.

Professorial and academic appointments are an area which is susceptible for science policy. The quality of the appointment procedures determines academic performance in a sense that incentives are created for scholars to pursue a certain research. strategy. ${ }^{450}$ Accurate assessments of scholarly productivity are needed not only to appoint productive scholars, but also for the incentive such procedures create for the scholars seeking appointment. These assessments are best left to the open scientific community, not to faculty, ${ }^{481}$ nor to an administration.

Property rights analysis indicates that the residual claimant, who has a good incentive to evaluate candidates, is most likely to look for the opinions of experts in the profession. Therefore, institutions should be devised, in which the right to appoint is attributed to the residual claimant. Because academic output is a public good, loaded with externalities, the acadernic residual is difficult to capture and normally takes the form of increased academic reputation or increased revenues from a growing tax base. Tie-ins can also be used to stimulate academic production or to raise private funds.

Academic compensation takes many forms. Research facilities and prestigious prizes are more likely to attract the pure curiosity scholars, while salaries and non-specified monetary prizes are more likely to stimulate the induced curiosity scholars. Professarial top salaries induce scholars down the hierarchy to be productive when in more junior positions. The salary system or a mixed salary-fee system is better attuned to the dual academic production of teaching and research, compared with the strict lecture fee system which would slow down research activities. ${ }^{452}$ Tenure, which is a typical characteristic of the açademic labor market, is important to protect. the specific investments of scholars. However, it is likely to lower academic performance and may entail rent-seeking costs, unless the academic administration continues to audit and discipline academic performance of the tenured academics. The non-specified awards provide a stimulus for basic research, much as the patent system works for applied research.

While transaction cost and property rights analysis point out that a hierarchical organization is a suitable form for academic production, public choice theory shows that bureaucratic inefficiency can be substantial. It is the result of information distortions, associated with the organizational structure of bureaucracy. Normally, the

480. Cfr. proposition 13

481. See proposition 12 .

482. See proposition 23 and recently: Bengt Holmstrom and Paul Milgrom (1991), "Multitask Principal-Agent Analysis: Incentive Contracts, Asset Ownership, and Job Design", Journal of Law, Economics \& Organizarion 7, special edition, pp. 24-52. 
information distortion results in a hierarchical loss of control which deteriorates when the span of control and the number of hierarchical levels increase. But the need for effective communication, economies in informal information processing and monitoring of strategic tasks can partly offset the structural information distortions, so typical for a bureaucracy. The scientific community is precisely the type of organization that can provide high-quality information to academic administrators. A vital task for an academic administration is the control over the quality of appointments. As in other lines of production, organizational planning is essential, but administrative planning of the scientific activity itself would be a complete waste of resources.

Academic performance in the public sector is not necessarily lower than in the private sector as long as the scientific community continues to perform its auditing and disciplinary role. But the public entrepreneur, who normally is a bureaucrat, has to put more energy in acquiring a sufficient degree of autonomy than his private sounterpart, who gets his autonomy through the market by being successful. The authority of the public bureaucrat depends on the size of the budget he administers, the strength of the financial, review and hierarchical constraints, and the opportunity cost of alternative employment, which is determined by his professional ability and the deference of politicians and other bureaucrats. Entrepreneurial capacity and bureaucratic performance are determined by the extent and intensity of the informal networks, in which the members render services to each other. Continuity enhances the development of networks, hence bureaucratic efficiency. While common education, goal congruence and brokerage can overcome network truncation, competition for membership can resolve network failures. 


\section{References}

ALCHIAN Armen A. [1958], "Private Property and the Relative Cost of Tenure", in: Economic Forces at Work [1970], Liberty Fund, Indianopolis, pp. 177-202.

ALCHIAN Armen and Harold DEMSETZ [1972], "Production, Information Costs, and Economic Organization", American Economic Review 62, no. 5, pp. 777-795.

ALCHIAN Armen A. and Susan WOODWARD [1987], "Reflections on the Theory of the Firm", Journal of Institutional and Theoretical Economics 143, pp. 110-137.

ANDERSON Gary M., David M. LEVY and Robert B. TOLLISON [1989], "The Half-Life of Dead Economists", Canadian Journal of Economics 22, no. 1, pp. 174 183.

AOKI Mashiko [1984], The Co-operative Game Theory of the Firm, Clarendon Press, New York/Oxford.

BACKHAUS Jürgen G. [1983], "Competition, Innovation and Regulation in the Pharmaceutical Industry", Managerial' and'Decision Economics 4, no, 2, pp. 107. 121.

BACKHAUS Jürgen G. [1989a], "Gustav Schmoller and the Problems of Today", Working Paper 89.009, University of Limburg, Maastricht, 24 pp.

BACKHAUS J.G. [1989b], "A Transaction Cost Approach to Explaining Historical Contract Structures", International Review of Law and Economics 9, pp. 223-226.

BACKIHAUS Jürgen G. [1989c], "The: University as an Economic Institution", Working Paper 89.017, University of Limburg, Maastricht, 29 pp.

BACKIHAUS Jürgen G. [1989d], "Workers' Participation Stimulated by the Economic Failure of Traditional Organization", Research Memorandum 89.11, University of Limburg, Maastricht, 39 pp.

BACKIHAUS, Jürgen G. [1990], Regulation and Selfregulation in the Knowledge Industry, Paper Symposium on Law and Economics, Lugano, 35 pp.

BALA,BKINS Nicholas W. [1989], From Schmoller to Althoff: Creating of a New Environment for Teaching and Research in Strassburg, 1872 - 1882, Paper Althoff Conference, Heilbronn, 16 pp. 
BAUMOL W.J. [1968], "Entrepreneurship in Economic Theory", American Economic Review 58, pp. 64-71.

BECKER Gary S. [1964], Human Capital, National Bureau of Economic Research, New York.

BECKER William E. Jr. [1975], "The University Professor as a Utility Maximizer and Producer of Learning, Research and Income", Journal of Human Resources 10, pp. 107-115.

BEN-DAVID Joseph [1971], The Scientist's Role in Society, University of Chicago Press, Chicago.

BLAUG Mark [1970], An Introduction to the Economics of Education, Penguin Books, Middlesex.

BOSCHAN Bärbel [1989], "Die Entwicklung der Philosophischen Fakultät der Berliner Universităt im Zeitraum 1870-1900", in: I.T.W., Friedrich Althoff 18391908, Akademie der Wissenschaften der DDR, Berlin, pp. 71-85.

BRENNAN H. Geoffrey and Robert D. TOLLISON [1980], "Rent Seeking in Academia", in: James M. BUCHANAN, Robert D. TOLLISON and Gordon TULLOCK (eds.), Toward a. Theory of the Rent-Seeking, Sociery, Texas A \& M Univerșity Press, pp. 345-356.

BRENTANO Lujo [1917], Elsässer Erinnerungen, Erich Reiss Verlag, Berlin.

BRETON Alber and Ronald WINTROBE, [1982], The Logic of Bureaucratic Conduct. An Economic Analysis of Competition, Exchange, and Efficiency in Private and Public Organizations, Cambridge Univ. Press, Cambridge.

Vom BROCKE Bernhard [1980], "Hochschul- und Wissenschaftspolitik in Preußen und im Deutschen Kaiserreich 1882-1907: das 'System Aithoff", in: BAUMGART Peter (Hrsg.), Bildungspolitik in Preußen zur Zeit des Kaiserreichs, Arbeitsgemeinschaft zur Preußischen Geschichte e.V., Band 1, Klett-Gotta, Stuttgart, pp. 7-119.

Yom BROCKE Bernhard [1981a], "Preußische Bildungspolitik 1700-1930", Abhandlungen, 1./15., pp. 727-746.

Vom BROCKE Bernhard [1981b], "Preußische Bildungspolitik von Gottfried Wilhelm Leibniz und Wilhelm von Humboldt bis Friedrich Althoff und Carl Heinrich Becker (1700-1930)", in: BÖHME W. (Hrsg.), Preußen - eine Herausforderung, Karlsruhe (Herrenalber Texte, 32), pp. 54-99. 
Vom BROCKE B. [1981c], "Der deutsch-amerikanische Professorenaustausch. Preußische Wissenschaftspolitik, internationale Wissenschaftsbeziehungen und die Anfänge einer deutschen auswărtigen Kulturpolitik vor dem Ersten Weltkrieg", Zeitschrift für Kulturaustausch, Institut für Auslandsbezichungen, Stuttgart, no. 31, pp. 128-182.

Vom BROCKE Bernhard [1985], "'Die Gelehrten'. Auf dem Weg zu einer vergleichenden Sozialgeschichte europäischer Bild̦ungssysteme und Bildungseliten im Industriezeitalter", Jahrbuch des italienisch-deutschen historischen Instituts in Trient, Società editrice il Mulino, Bologna, pp. 389-401.

Vom BROCKE Bernhard [1987], "Friedrich Althoff", in: TREUE Wolfgang und Karlfried GRÜNDER (Hrsg.), Berlinische Lebensbilder Wissenschaftspolitik in Berlin. Minister, Beamte, Ratgeber, Colloquium Verlag, Berlin, pp. 195-214.

Vom BROCKE Bernhard [1988], "Von der Wissenschaftsverwaltung zur Wissenschaftspolitik: Friedrich Althoff (19.2.1839-20.10.1908)" Beriche zur Wissenschaftsgeschichte, VCB Verlagsgesellschaft, Weinheim, no. 11, pp. 1-26.

Vom BROCKE Bernhard [1989a], "Vorgeschichte, Gründung und Entwicklung der Kaiser-Wilhelm-Gesellschaft zur Förderung der Wissenschaften - Der Anteil Friedrich Althoffs", in: I.T.W., Friedrich Althoff 1839-1908, Akademie der Wissenschaften der DDR, Berlin, pp. 129-163.

Vom BROCKE Bernhard [1989b], From Science Administration to a Policy of Science: An Appraisal of Friedrich Althoff (2/19/1839-10/20/1908), Paper Althoff Conference, Heilbronn, Germany, 43 pp.

Vom BROCKE Bernhard and Rudolf VIERHAUS [1990], Forschung im Spannungsfeld von Politik und Gesellschaft, Deutsche Verlagsanstalt, Stuttgart.

Vom BROCKE Bernhard [199la], "Friedrich Althoff: A Great Figure in Higher Education Policy in Germany", Minerva 29, no. 3, pp. 269-293.

Vom BROCKE Bernhard (Hrsg.) [1991b], Wissenschaftsgeschichte und Wissenschafispolitik im Industriezeitalter, Verlag August Lax, Hildesheim.

BUCHANAN James [1969], Cost and choice, Markham, Chicago.

BUCHANAN James M. and Viktor VANBERG [1989], "A Theory of Leadership and, Deference in Constitutional Construction", Public Choice 61, pp. 15-27.

BUCHANAN James M., Robert D. TOLLISON and Gordon TULLOCK (eds.) [1980], Toward a Theory of the Rent-Seeking Sociery, Texas A \& M University Press. 
BUTLER Nicholas Murray [1940], Across The Busy Years: Recollections and Reflections, Charles Scribner's Sons, New York, 2 vol.

CALDER William M. [1991], "Die Rolle Friedrich Althoffs bei den Berufungen von Ulrich von Wilamowitz-Moellendorf", in: Bernhard vom Brocke (Hrsg.), Wissenschaftsgeschichte und Wissenschaftspolitik im Industriezeitalter, Verlag August Lax, Hildesheim, pp. 251-266.

CARMICHAEL H. Lorne [1988], "Incentives in Academics: Why is There Tenure?", Journal of Political Economy 96, no. 3, pp. 453-472.

CASSON Mark [1982], The Entrepreneur, Martin Robertson, Oxford.

COASE R.H. [1937], "The Nature of the Firm", in: The Firm, the Market and the Law [1988], University of Chicago Press, Chicago, pp. 33-56.

COASE Ronald H. [1960], "The Problem of Social Cost", Journal of Law and Economics 3, pp. 1-44.

COASE Ronald H. [1988], The Firm, the Market and the Law, University of Chicago Press, Chicago.

COATS A.W. [1987], The Institutionalization of Political Economy in European, American and Japanese Universities, Paper Fifth HESA Conference, 45 pp.

COLANDER David [1989], "Research on the Economics Profession", Journal of Economic Perspectives 3, no، 4. pp. 137-148.

CRAIG John E. [1984], Scholarship and Nation Building. The Universities of Strasbourg and Alsatian Society, 1870-1939, University of Chicago Press, Chicago and London.

CROCKER Thomas D. [1971], "Externalities, Property rights and Transaction Costs: An Empirical Study", Journal of Law and Economics 14, pp. 445-463.

DAVIS Paul and Gustav F. PAPANEK [1984], "Faculty Ratings of Major Economics Departments by Citations", American Economic Review 74, no. 1, pp. 225-230.

DAWSON W.H. [1919], The German Empire 1867-1914 and the Unity Movement, Macmillan, New York, 2 vol.

DE ALESSI Loius [1969], "Implications of Property Rights for Government Investment Choices", American Economic Review, 59, pp. 13-24.

DEMSETZ [1967], "Toward a Theory of Property Rights", American Economic Review 57, pp. 347-359. 
DEMSETZ Harold [1970], "The Private Production of Public Goods", Journal of Law and Economics 13, no. 2, pp. 293-306.

DIAMOND Arthur M. Jr. [1988], "The Empirical Progressiveness of the General Equilibrium Research Program", History of Political Economy 20, no. 1, 119-135.

DIAMOND Arthur M. Jr. [1989a], Economic Explanations of the Behavior of Universities and Scholars, Paper Annual Meeting of the North American Economics and Finance Association, Atlanta, Georgia, 45 pp.

DIAMOND Arthur M. Jr. [1989b], "Most-Cited Papers and Current Rescarch Fronts", Current Contents 21, no. 2, pp. 3-8.

DILORENZO Thomas J. [1988], "Property Rights, Information. Costs and the Economics of Rent-Seeking", Journal of Theoretical and Institutional Economics 144, no. 2, pp. 318-332.

DOWNS Anthony [1967], Inside Bureaucracy, Little Brown, Boston.

FAMA Eugene F. [1980], "Agency Problems and the Theory of the Firm", Journal of Political Economy 88, no. 2, pp. 288-307.

FRANK Robert H. [1984], "Are Workers Paid Their Marginal Products ?"', American Economic Review 74, no. 4, pp. 549-57.1.

FREEMAN Smith [1977], "Wage Trends as Performance Displays Productive Potential: A. Model and Application of Academic Early Retirement, Bell Journal of Economics 8, pp. 419-443.

FREY' Bruno S. [1986], "Human Behavior: Possibilities Explain Action", Journal of Economic Psychology 7, pp. 138-160.

FURUBOTN Eirik G. and Svetozar PEJOVICH [1974], The Economics of Property Rights, Ballinger, Cambridge, Mass..

FURUBOTN Eirik G. and Svetozar PEJOVICH [1972], "Property Rights and Economic Theory", Journal' of Economic Literature 10, no. 4, pp: 1137-1162.

FURUBOTN Eirik G. [1989], An Economic Analysis of the Althoff System: Comments, Discussion Paper Althoff Conference, Heilbronn, 15 pp.

GARVIN David A. [1980], The Economics of University Behavior, Academic Press, New York.

GERRITY Dennis M. and Richard B. McKENZIE [1978], "The Ranking of Southern Economics Departments: New Criterion and Further Evidence", Southern Economic Journal 45, pp. 608-614. 
GOFF Brian L., William F. SHUGHART II, Robert D. TOLLISON and Stephen B. POCIASK [1987], "The Incentive to Cite", Journal of Institutional and Theoretical Economics 143, pp. 467-476.

GROOT T.L.C.M. [1988], Management van Universiteiten, Wolters-Noordhoff, Groningen.

GRUBEL Herbert G. and Lawrence A. BOLAND [1986], "On the Efficient Use of Mathematics in Economics: Some Theory, Facts and Results of an Opinion Survey", Kyklos 39, pp. 419-442.

HAMERMESH Daniel S., George E. JOHNSON and Burton A. WEISBROD [1982], "Scholarship, Citations and Salaries: Economic Rewards in Economics", Southern Economic Journal 49, no. 2, pp. 472-481.

HANUSHEK Eric A. [1986], "The Economics of Schooling", Journal of Economic Literature 24, no. 3, pp. 1141-1177.

HA.RT Oliver and John MOORE [1990], "Property Rights and the Nature of the Firm", Journal of Political Economy 98, no, 6, pp. 1119-1158.

HÖFLECHNER Walter [1989], The Impact of the Prussian and German University Administrations on the Austrian University System between 1875 and 1914, Paper Althoff Conference, Heilbronn, $19 \mathrm{pp}$.

HÖFLECHNER Walter [1991], "Zum Einfluß der deutschen Hochschulwesens auf Österreich in den Jahren 1875-1914", in: Bernhard vom Brocke (Hrsg.), Wissenschaftsgeschichte und Wissenschaftspolitik im Industriezeitalter, Verlag August Lax, Hildesheim, pp. 155-185.

HOGAN Timothy D. [1973], "Rankings of Ph.D. Programs in Economics and the Relative Publishing Performance of Their Ph.D.'s", Western Economic Journal II, pp. 10-25.

HOLMSTROM Bengt and Paul MILGROM [1991], "Multitask Principal Agent Analysis: Incentive Contracts, Asset Ownership, and Job Design", Journal of Law, Economics \& Organization 7, special edition, pp. 24-52.

HOLTMANN A.G. and Allan E. BAYER [1970], "Determinants of Professional Income Among Recent Recipients of Natural Science Doctorates", Journal of Business 43, no. 4, pp. 410-418.

HOLTMANN A.G. [1988], "Theories of Non-Profit Institutions", Journal of Economic Surveys 2, no. 1, pp. 29-45.

JAMES Estelle and Egon NEUBERGER [1981], "The University Department as a Non-Profit Labor Cooperative", Public Choice 36, pp. 585-312. 
JENSEN M.C. and W.H. MECKLING [1976]. "Theory of the Firm: Managerial Behavior, Agency Costs and Ownership Structure", Journal of Financial Economics 3. pp. $305-360$.

JOHNSON Harry G. [1973], "The University and Social Welfare", Minerva 11. no. 1 , pp. $30-52$.

JOHNSON George E. and Frank P. STAFFORD [1974], "Lifetime Earnings in a Professional Labor Market: Academic Economists", Journal of Political Economy 82, no. 3, pp. 549-569.

KAHLOW Andreas [1989], "Der Technikerstreit im letzten Drittel des 19. Jahrhunderts", in: I.T.W., Friedrich Althoff 1839-1908, Akademic der Wissenschaften der DDR, Berlin, pp. 115-128.

KATZ David A. [1973], "Faculty Salaries, Promotions and Productivity at a Large University", American Economic Review 63, no. 3, pp. 469-477.

KIRZNER Israel M. [1973], Competition and Entrepreneurship, Univ. of Chicago Press, Chicago.

KNIGHT Frank [1921], repr. [1971], Risk, Uncertainty and Profit, Univ. of Chicago Press, Chicago.

KRUEGER Anne O. [1974], "The Political Economy of the Rent-Seeking Society", American Economic Review 64, pp. 291-303.

KUHN Thomas S. [1970], The Structure of Scientific Revolutions, University of Chicago Press, Chicago.

LABAND David N. [1986], "Article Popularity", Economic Inquiry 24, pp. 173-180.

LAITKO Hubert [1989], "Alexander von Humboldt und Friedrich Althoff: Zur Tradition selektiver Wissenschaftssteuerung durch Förderung von Hochbegabungen", in: I.T.W., Friedrich Althoff 1839-1908, Akademie der Wissenschaften der DDR, Berlin, pp. 1-15.

LAKATOS I. and A. MUSGRAVE (eds.) [1970], Criticism and the Growth of Knowledge, Cambridge University Press, Cambridge.

LAZEAR Edward P. and Sherwin ROSEN [1981], "Rank-Order Tournaments as Optimum Labor Contracts", Journal of Political Economy 89, no. 5, pp. 841-846.

LEIBENSTEIN Harvey [1968], "Entrepreneurship and Development", American Economic Review 58, pp. 72-83. 
LISCHKE Ralph-Jürgen [1989], "Friedrich Althoff und die preußisch-deutsche Wissenschaftspolitik", in: I.T.W., Friedrich Althoff 1839-1908', Akademie der Wissenschaften der DDR, Berlin, pp. 16-34.

LOVELL Michael C. [1973], "The Production of Economic Literature: An Interpretation", Journal of Economic Literature II, no. I, pp. 27-55.

MACHLUP Fritz [1982], Knowledge: Its Creation, Distribution and Economic Significance (vol. 2: The Branches of Learning), Princeton University Press, Princeton.

McCORMICK Robert E. and MEINERS Roger E. [1988], "University Governance: A Property Rights Perspective", Journal of Law and Economics 31, no. 2, pp. 423442.

McKENZIE Richard B. [1979], "The Economic Basis of Departmental Discord in Academe", Social Science Quarterly 59, no. 4, pp. 653-664.

MERTON Robert: K. [1973], The Sociology of Science: Theoretical and Empirical Investigations, University of Chicago Press, Chicago.

MIGUE J. and G. BELANGER [1974], "Toward a General Theory of Managerial Discretion", Public Choice 17, pp. 27-43.

MINCER Jacob [1974], Schooling, Experience and Earnings, National Bureau for Economic Research, New York.

Von MiSES Ludwig [1949], Human Action, Yale Univ. Press, New Haven.

MOWERY David C. [1990], "The Development of Industrial Research in U.S. Manufacturing", American Economic Review 80, no. 2, Papers. \& Proceedings, pp. 345-349.

MUSGRAVE Richard Abel [1938], "The Voluntary Exchange Theory of Public Economy", Quarterly Journal of Economics 53, no., 2, pp. 213-237.

NEBELIN Manfred [1990], "Friedrich Althoff", in: Kurt G.A. JESERICH and Helmut NEUHAUS (Hrsg.), Persônlichkeiten der deutschen Verwaltung. Biographien zur. Verwaltungsgeschichte 1648-1945, Kohlhammer-Verlag, Stuttgart, pp. 426-429.

NELSON Richard R. [1986], Institutions Supporting Technical Change in: Industry, Research Paper, Yale University, 54 pp.

NISKANEN W.A. [1971], Bureaucracy and Representative Government, AldineAtherton, Chicago. 
NORTH Douglass C. [1990], Institutions, Instinutional Change and Economic Performance, Cambridge Univ. Press, Cambridge.

OLSON Mancur [1973], "Evaluating Performance in the Public Sector" "in: Milton MOSS (ed.), The Measurement of Economic and Social Performance, Studies in Income and Wealth 38, NBER, Columbia Univ. Press, New York, pp. 355 - 384.

PARSONS Donald O. [1986], "The Employment Relationship: Job Attachment, Work Effort and the Nature of Contracts", in: O. ASCHENFELTER and R. LAYARD (eds.). Handbook of Labor Economics, vol. 2, Elsevier, Amsterdam. pp. 789-848.

PEIRCE William S. [1981a], Bureaucratic Failure and Public Expenditure, Ácademic Press, New York.

PEIRCE William S. [1981b], "Bureaucratic Politics and the Labor Market", Public Choice 37, pp. 307-320.

PEIRCE William S. [1983]" "Repealing Parkinson's Law: Incentives to Encourage Bureaucrats to Save the Taxpayers' Money". Research Paper, Case Western Reserve University, $51 \mathrm{pp}$.

PEIRCE William S. and Peter KRUEGER [1989], Entrepreneurship in a Bureaucracy, Paper Althoff Conference, Heilbronn, 45 pp.

PFETSCH Frank [1974], Zur Entwicklung! der Wissenschaftspolitik in Deutschland 1850-1914, Duncker \&. Humblot, Berlin.

POPPER Karl R. [1934], repr. [1976], Logik der Forschung, Mohr, Tübingen.

POPPER Karl R. [1963], Conjectures and Refutations: The Growth of Scientific Knowledge, Routledge and Kegan Paul, London.

PSACHAROPOULOS George (ed.) [1987], Economics of Education: Research and Studies, Pergamon Press, Oxford.

RASCH Manfred [1990], "Thesen zur Preußischen Wissenschaftspolitik gegen Ende des Wilhelminischen Zeitalters", Berichte zur Wissenschaftsgeschichte, VCB Verlagsgesellschaft, Weinheim, nr. 12, pp. 240-252.

ROSEN Sherwin [1985], "Implicit Contracts: A Survey", Journal of Economic Literature 23, no. 3, pp. 1144-1175.

ROSEN Sherwin [1986], "Prizes and Incentives in Elimination Tournaments.", American Economic Review 76, pp. 701-715.

ROSEN Sherwin [1987], "Some Economics of Teaching", Journal of Labor Economics 5, no. 4, pp. 561-575. 
ROTHMAN Bernhard and Charles STREIN [1982], "The University Administrator as a Utility Maximizer", Rivista Internazionale di Scienze Economiche e Commerciali 29, no. 5, pp. $451-464$.

SAMUELSON P.A. [1954], "The Pure Theory of Public Expenditures", Review of Economics and Statistics 36, pp. 387-389.

SCHILFERT Sabine [1989], "Friedrich Althoff und die wissenschaftlich-technischen Hochschulbibliotheken - Eine Studie zum Arbeitsstil Althoffs", in: I.T.W., Friedrich Althoff 1839-1908, Akademie der Wissenschaften der DDR, Berlin, pp. 101-114.

SCHOLZ Hartmut [1989], "Friedrich Althoffs Einfluß auf die Entwicklung der Chemie in Deutschland Ende des 19. Jahrhunderts", in: I.T.W., Friedrich Althoff 1839-1908, Akademie der Wissenschaften der DDR, Berlin, pp. 86-100.

SCHUMPETER Joseph A. [1934], The Theory of Economic Development, Harvard Univ. Press, Cambridge Mass.

SCHWARZ Otto [1911], "Stiftungen", in: Handwörterbuch der Staatswissenschaften (3rd ed.), vol. 7., Jena, p. 1017.

SEINN Peter R. [1989], Where is Althoff? Friedrich Althoff in English: How has he fared?, Paper Althoff Conference, Heilbronn, $66 \mathrm{pp}$.

SHILS Edward [1973], "The Power of the State and the Dignity of the Academic Calling in Imperial Germany: The Writings of Max Weber on University Problems", Minerva 11, no. 4, pp. 571-632.

SIEG Ulrich [1991], "Im Zeichen der Beharrung. Althoffs Wissenschaftspolitik und die deutsche Universitätsphilosophie", in: Bernhard vom Brocke (Hrsg.), Wissenschafisgeschichte und Wissenschaftspolitik im Industriezeitalter, Verlag August Lax, Hildesheim, pp. 287-306.

SMITH Adam [1776], repr. [1976], An Inquiry Into the Nature and Causes of the Wealth of Nations, Clarendon Press, Oxford, 2 vol.

SPENCE Michael [1973], "Job Market Signaling", Quarterly Journal of Economics 87. pp. 355-374.

SPINNER Helmut [1991], "Das 'System' Althoff und Max Webers Kritik", in: Bernhard vom Brocke (Hrsg.), Wissenschaftsgeschichte und Wissenschaftspolitik im Industriezeitalter, Verlag August Lax, Hildesheim, pp. 503-563.

STIGLER George J. and Claire FRIEDLAND [1975], "The Citation Practices of Doctorates in Economics", Journal of Political Economy 83, no. 3, pp. 477-507. 
STIGLER George J, and Claire FRIEDLAND [1979], "The Pattern of Citation Practices in Economics", History of Political Economy 11, no. 1, pp. 1-20.

TIEMANN Klaus-Harro [1989], "Das Zusammenwirken von W.J. Foerster und F.T. Althoff auf dem Gebiet der Geo- und Kosmoswissenschaften", in: I.T.W., Friedrich Althoff 1839-1908, Akademie der Wissenschaften der DDR, Berlin, pp. 57-70.

TOBIES Renata [1989], "Zum Verhãltnis von Felix Klein und Friedrich Althoff", in: I.T.W., Friedrich Althoff 1839-1908, Akademie der Wissenschaften der DDR, Berlin, pp. 35-56.

TOBIES Renata [1991], "Wissenschaftliche Schwerpunktbildung: der Ausbau Göttingens zum Zentrum der Mathematik und Naturwissenschaften", in: Bernhard vom Brocke (Hrsg.), Wissenschaftsgeschichte und Wissenschaftspolitik im Industriezeitalter, Verlag August Lax, Hildesheim, pp. 87-108.

TUCKMAN Howard P., J. GAPINSKI and Robert P. HAGEMANN [1977], "Faculty Skills and the Salary Structure in Academe: A. Market Perspective", American Economic Review 67, pp. 692-702.

TULLOCK Gordon [1965], The Politics of Bureaucracy, Public Affairs Press, Washington.

TULLOCK Gordon [1966], The Organization of Inquiry, Duke Univ. Press, Durham. N.C..

TULLOCK Gordon [1967], "Welfare Costs of Tariffs, Monopolies and Theft", Western Economic Journal 5, pp. 224-232.

VEREECK Lode [1991], "Das System Althoff: Eine ökonomische Verhaltensanalyse", in: Bernhard vom Brocke (Hrsg.), Wissenschaftsgeschichte und Wissenschafispolitik im Industriezeitalter. Das "System Althoff" in historischer Perspektive, Verlag Lax, Hildesheim, pp. 485-502.

WENDEL Günther [1991], "Aktivitātẹn Althoffs zum Wegennnetz europãischen Geistes. Die Einbeziehung ost- und sudeuropäischer Universitäten in das System Althoffs", in: Bernhard vom Brocke (Hrsg.), Wissenschaftsgeschichte und Wissenschaftspolitik im Industriezeitalter, Verlag August. Lax, Hildesheim, pp. 123154.

WEST E.G. [1970], Education and the State, Institute of Economic Affairs, London.

WILLIAMSON Oliver E. [1967], "Hierarchical Control and Optimum Firm Size", Journal of Political Economy 75, no. 2, pp. 123-138.

WILLIAMṢON, Oliver E. [1979], "Transaction-Cost Economics: The Governance of Contractual Relations, Journal of Law and Economics 22, no. 1, pp. 233-261. 
WILLIAMSON Oliver E. [1985], The Economic Institutions of Capitalism, Free Press, New York.

WILSON R. [1975], "Informational Economies of Scale", Bell Journal of Economics 6, no. 1, pp. 184-195.

WOLPIN Kenneth 1. [1977], "Education and Screening", American Economic Review 67 , no. 5, pp. 949-958.

ZIRNSTEIN Gottfried [1991], "Friedrichs Althoffs Wirken für die Biologie in der Zeit des Umbruchs der biologischen Disziplinen in Deutschland, der Erneuerung ihrer Forschung und Lehre an dẹ Universitäten und des Rufes nach außeruniversităren Forschungsstătten, 1882 bis 1908", in: Bernhard vom Brocke (Hrsg.), Wissenschaftsgeschichte und Wissenschaftspolitik im Industriezeitalter, Verlag August Lax, Hildesheim, pp. 355-374. 


\section{Appendix}

\section{A.1. List of Assumptions}

1. Academic output is a public good, loaded with externalities.

2. The economic properties of academic output make it very difficult to assess its value by means of quantitative indicators alone.

3. The scientific community is an informal social organization that coordinates the activities of scholars.

4. The auditing procedures of the scientific community consist of the continuing and alternating process of verification and dissemination of academic output.

5. Transaction costs consist of the costs of information gathering, contracting and monitoring. 


\section{A.2. List of Observations}

1. Althoff was the leading public administrator of science in Germany for a quarter of a century.

2. Althoff's "personal regime" is characterized by an autonomous and autocratic working style, a strong personal administration and independent professionalism.

3. Althoff had excellent contacts with the Imperial Court and obtained the exceptional right of direct address to the Emperor.

4. The international recognition of German science and scholarship was a major objective of the Althoff system.

5. The Prussian Ministry of Culture was organized as a typical hierarchical bureaucracy.

6. Althoff could rely on a professional staff of experts in his department.

7. Althoff operated beyond the formal limits of the authority invested in him.

8. The Ministry of Culture coordinated the initiatives in the field of science and education in Prussia.

9. Prussia determined the science policy of Germany.

10. The Austrian university system had the special mission to integrate the different peoples of the Austrian-Hungarian Empire.

11. Althoff used many media to promote the policy and the achievements of his department.

12. The traditional university system was no longer able to cope with the growing demand for its services.

13. Althoff was an experienced manager of science when he assumed a position in the Prussian Ministry of Culture.

14. The academic system, taking the form of a large bureaucracy, expanded rapidly in the Althoff era.

15. Althoff bureaucratized the academic system, which he ran as an integrated system of all academic institutes.

16. Research institutes were created that were independent of the traditional universities, in order to allow scholars to devote their efforts solely to research.

17. The seminar method was a new form of interactive education and research. 
18. The reform of the German scientific library system was twofold. expansion and structural reorganization.

19. Althoff made the university regulations and degree requirements more consistent and less discriminating.

20. The academic staff earned a basic salary according to a wage scale system for the Prussian bureaucracy, that was supplemented by lecture fees.

21. Top scholars earned top wages and researchers of genius obtained their own research institute.

22. Marks of honor were an important compensation instrument in the Althoff system.

23. The Ministry of Culture conducted an active international science policy in order to obtain international recognition of German science and scholarship.

24. The Althoff system marks the start of statistical studies, that would underlie the modern administration of science in Germany.

25. An extensive, informal network of confidential agents provided Althoff with qualitative academic information as well as additional financial resources.

26. When Althoff appointed a member of the academic staff, he combined expert knowledge on the scientific situation of a discipline with accurate scholarly appraisals of the academic performance of the candidate.

27. Althoff respected the traditional academic rights as long as they were not used for the protection of vested interests.

28. The autocratic "personal regime" of Althoff was not absolute.

29. Althoff not only appointed suitable candidates to existing chairs, he also created new positions with excellent research facilities in order to attract top scholars.

30. Althoff gave scholars who belonged to a minority group equal opportunities to an academic career.

31. The Ministry of Culture protected academic freedom as guaranteed by the constitution.

32. Althoff built a multi-source financing system for the academic system.

33. Orders, ennoblement and licences were specific incentives to attract private money for academic research. 


\section{A.3. List of Propositions}

1. The auditing and disciplinary procedures of the scientific community exert such pressure on the scholars that it brings about a high level of quality and accuracy in academic output.

2. The scientific community generates and stores information about the value of academic output.

3. Dissemination of scientific knowledge is a necessary condition for the audit of academic output by the scientific community.

4. Well-organized libraries may improve academic performance by lowering the search costs of scholars and by facilitating the dissemination of scientific knowledge.

5. The transactional characteristics of academic production reveal a need for a specific academic governance structure.

6. Monitoring academic production by using the market entails substantial transaction costs.

7. The voluntary auditing procedures of the scientific community may lower the monitoring costs of academic production.

8. The faculty system is patterned after the needs of the educational system and of individual research activity.

9. Research institutes are patterned after the needs of academic team production.

10. The ultimate control of the academic output of an institute remains with the scientific community although team production clearly offers internal monitoring advantages.

11. The evaluation of academic output as an instrument of controll should be the rule, evaluation of input behavior the exception.

12. It is rational for faculty to be ignorant about the research performance of present and potential faculty members.

13. The quality of the screening and subsequent signaling variables in selection procedures, determines academic performance.

14. The right to claim the residual gives an important incentive to the holder of the right to carefully monitor academic scholars and evaluate candidates.

15. The academic residual can take the form of increased academic reputation or of increased revenues from an increased tax base. 
16. Academic compensation, which is not likely to reflect the marginal productivity of a scholar, functions as an incentive for academic performance.

17. Research facilities and scientific prizes are likely to stimulate the performance of the pure curiosity scholars.

18. Salaries and non-specified monetary prizes are likely to stimulate the performance of the induced curiosity scholars.

19. Non-specified awards may provide a stimulus for basic research, much as the patent system works for applied research.

20. Tenure is likely to lower academic performance, unless the scientific community continues to perform its auditing and disciplinary role.

21. Academic tenure may entail substantial rent-seeking costs as well as benefits.

22. Tenure protects the idiosyncratic investments of the tenured scholar.

23. The salary system is better attuned to the dual academic productioni of teaching and research than is the (strict) fee system.

24. Teaching and research can be separated as long as academic output is freely disseminated.

25. Loyalty and discipline reduce the monitoring costs of production.

26. Structural bureaucratic inefficiency results from information distortions.

27. Hierarchical loss of control is likely to occur' when the span of control and the number of hierarchical levels increase.

28. Economies of scale in information gathering can offset managerial overload.

29. The need for effective communication may offset information distortions.

30. Academic performance is likely to be lower in the public sector unless the scientific community performs its auditing and disciplinary role.

31. The authority of a bureaucrat depends on the ability to maximize the budget of the department in which he is working.

32. If monitoring by the sponsor takes place in order to modify bureaucratic overexpansion, the authority of the bureaucrat depends on the ability to reduce the financial and review constraints.

33. Bureaucrats who forgo the standard forms of compensation, create an opportunity for independent behavior.

34. Professional ability and behavior strengthen the authority of a bureaucrat. 
35. Rational deference strengthens the authority of the informed bureaucrat.

36. Bureaucratic performance is dependent on the informal services rendered to the bureau.

37. Bureaucratic performance is dependent on the intensity and the extent of internal networks.

38. Continuity is likely to improve selective bureaucratic behavior.

39. A public entrepreneur has to acquire a sufficient degree of autonomy.

40. Entrepreneurial capacity is determined by the extent and the intensity of the networks that are set up by the entrepreneur. 


\section{A.4. List of Hypotheses}

1. The Althoff system stimulated academic performance by keeping the scientific community open and by improving the dissemination of knowledge.

2. The Althoff system created a transaction-specific governance structure for academic production.

3. The hierarchical Althoff system captured more free externalities of academic production than the decentralized academic system.

4. Althoff's independent research institutes and seminars stimulated formal academic team production.

5. Althoff improved the selection of academic scholars in Prussia by processing information generated by a network in the scientific community.

6. The Althoff system stimulated academic performance not only by appointing productive scholars, but also by the incentive value of its screening method.

7. The Althoff system improved the quality of academic appointments by having the residual claimant make the final decision.

8. The Althoff system is likely to have set an efficient level of compensation, since the residual claimant determined academic rewards.

9. In accordance with human capital and implicit contract theory, the Althoff system paid low starting salaries for young scholars and huge wages for top scholars.

10. The Althoff system reduced the disadvantages of academic tenure.

11. A manageable span of control and a comparative information advantage contained the bureaucratic costs of the: Althoff system.

12. The multi-source financing system strengthened Althoff s authority.

13. Althoff's authority was based on professionalism.

14. Althoff's network improved the performance of the bureaucratic and academic system.

15. Althoff was a public entrepreneur. 


\section{A.5. List of Conclusions}

1. The international recognition of German science and scholarship in the Althoff era reflected its academic performance.

2. The Althoff system improved the performance of the German academic system.

3. Policy measures that aim at keeping the scientific community open are likely to improve academic performance.

4. Policy measures that aim at enhancing the dissemination and verification of academic output are likely to improve academic performance.

5. Policy measures can improve the quality of academic decisions, hence academic performance.

6. Academic statistics have incentive value for scholarly performance, but should not be used as policy targets.

7. The economic theory of science and scholarship demonstrates that institutional conditions are an important determinant of academic performance.

8. The economic theory of science and scholarship points out how the institutional conditions in the academic system affect scholarly performance. 


\section{Summary}

In comparison with the literature in sociology and philosophy, the economic analysis of science and scholarship is a relatively infant line of research. The purpose of this study is to make a theoretical and empirical contribution to this field in order to improve our knowledge about the institutional requirements for academic production and productivity.

The analysis starts by investigating Prussian science policy at the turn of this century, often referred to as the "Althoff system". The system was named after the Prussian administrator of science Friedrich Althoff (1839-1908). He introduced many institutional innovations which were implemented in the academic system. Among his reforms were the creation of independent research institutes, seminars and a professional national library system, the uniformization of university regulations, the creation of a performance-based compensation scheme for scholars and a multi-source financing system. Being the leading bureaucrat at the Prussian Ministry of Culture in Berlin, Althoff was mainly in charge of professorial appointments and academic compensation. Well informed by a whole network of scholars, he was often in a better position than the faculties to assess the qualities and productivity of candidates. He was particularly successful in identifying and helping researchers of true genius and scholars belonging to minorities.

Using a micro-economic model that describes the economic behavior of scholars and their interaction in the scientific community, an attempt is made to explain the effects of the Althoff system on scholarly performance and to spell out the institutional requirenments for productive academic activity. Building on the new institutional economics, the basic model is further developed by taking into account the transaction costs of scholarly production and the effect of the distribution of academic property rights, in particular the right to appoint and to determine compensation, on academic performance. The role of science administrators, in general, and Althoff, in particular, is analysed with the help of the public choice theories; of bureaucratic behavior and public entrepreneurship.

The economic analysis draws to the conclusion that the Althoff reforms significantly upgraded the academic productivity of German scholars, who were internationally recognized. Finally, the study lays down some guidelines for an active science policy. 


\section{Samenvatting}

In vergelijking met de wetenschapsfilosofie en de wetenschapssociologie is de economische analyse van de wetenschap een jonge discipline. Deze studie tracht een theoretische en empirische bijdrage te leveren tot dit domein.

Meer bepaald wordt getracht een (economische) verklaring te vinden voor de uitzonderlijke wetenschappelijke produktiviteit van het Pruisisch academisch systeem. Daarbij gaat bijzondere aandacht uit naar het wetenschapsbeleid van Friedrich Althoff (1839-1908), wiens politiek vaak aangeduid werd met het "Althoff systeem". Eerst wordt gewezen op de talrijke institutionele innovaties die Althoff invoerde, gaande van de oprichting van onafhankelijke onderzoeksinstituten en seminaries, de professionalisering van het bibliotheeksysteem, de gelijkschakeling van. universiteitsregels en de vernieuwing van het vergoedingsstelsel van wetenschappers en het financieringsstelsel van het academisch systeem tot en met de invoering van een daadwerkelijk "internationaal" wetenschapsbeleid. Opmerkelijk is echter vooral de wijze waarop Althoff als hoge ambtenaar te Berlijn direct ingreep op de academische arbeidsmarkt. Uitstekend geīnformeerd door een netwerk van wetenschappelijke informanten, benoemde hij de professoren vaak tegen de wil van de faculteiten in. Toptalenten en minderheden konden rekenen op zijn voortdurende steun en inzet.

Met behulp van een micro-economisch model, dat het gedrag van wetenschappers en de rol van de wetenschappelijke gemeenschap beschrijft, wordt geprobeerd de verwezenlijkingen van het Althoff systeem te verklaren en de institutionele voorwaarden voor academische productiviteit vast te stellen. De invalshoek die daarvoor gekozen is, is die van de neo-institutionele economie. Aandacht wordt dan ook besteed aan de transactiekosten van wetenschappelijke produktie en het effect van de verdeling van academische beslissingsrechten zoals het benoemings- en beloningsrecht, op de wetenschappelijke produktie. Ook het bureaucratisch gedrag of publiek ondernemerschap van hoge wetenschapsambtenaren in het algemeen en Althoff in het bijzonder wordt geanalyseerd.

Als besluit van de (neo-institutionele) economische analyse kan gesteld worden dat de maatregelen die in het Althoff systeem genomen werden, de wetenschappelijke productiviteit van de academische wetenschapper ten goede kwamen. Tot slot tracht de studie aan te geven waar de mogelijkheden en de beperkingen liggen voor een actief wetenschapsbeleid. 


\section{Zusammenfassung}

Im Vergleich mit der Wissenschaftsphilosophie und der Wissenssoziologie ist die ōkonomische Analyse der Wissenschaft und der Wissensordnung eine junge Disziplin. Diese Studie stellt einen. theoretischen und empirischen Beitrag zu dieser jungen Disziplin dar:

Der Versuch wird unternommen, die außerordentliche wissenschaftliche Produktivităt des historischen Preussischen akademischen Systems zu erklären und die wesentlichen Determinanten dieses Erfolges herauszuarbeiten. Die historisch abgeschlossene Periode fallt zusammen mit der Wissenschaftspolitik Friedrich Althoffs, die oft als "System Althoff" bezeichnet wird. Zunächst geht es um eine Zusammenstellung der vielfaltigen institutionellen Innovationen, die Althoff einführte, angefangen von der Errichtung unabhăngiger Forschungsinstitute und Seminare über die Professionalisierung der Bibliothekeni und der. Bibliothekare, die Gleichstellung der Universitătsprüfungen und diẹ Modernisierung des Entlohnungswesens für die Wissenschaftler und des Finanzierungsstatuts des akademischen Systems bis hin zur Einführung einer international abgestimmten Wissenschaftspolitik. Besonders ins Auge fallt die Tatsache, daß Althoff als hoher Beamter in Berlin direkt und indirekt in den akademischen Arbeitsmarkt eingriff. Hervorragend durch ein Netzwerk wissenschaftlicher Gutachter informiert, setzte er manchmal auch gegen den Willen der Fakultăten die Berufung von Professoren durch, so daß die hochqualifizierten Wissenschaftler auch dann auf seine Unterstũtzung rechnen konnten, wenn sie Minderheiten entstammten, gegen die die offizielle Politik. diskriminierend auftrat.

Mithilfe eines im Grunde mikroökonomischen Modells, das das Vẹrhalten dẹr Wissenschaftler und die Rolle der wissenschaftlichen Gemeinschaft beschreibt, wird versucht, die wesentlichen Kennzeichen und Funktionsweisen des Althoff Systems zu erklären und die institutionellen Determinanten produktiven akademischen Arbeitens herauszuarbeiten. Diese Analyse schließt bei den Entwicklungen auf dem Gebiete der neuen Institutionenökonomik an. Deshalb stehen die Transaktionskosten bei der wissenschaftlichen Produktion im Mittelpunkt der Analyse, ebenso die Folgen der Zuweisung akademischer Entscheidungsrechte, wie des. Berufungsrechtes und des Rechtes, die Entlohnung festzusetzen, auf die wissenschaftliche Produktion. Ebenfalls analysiert werden bürokratische Verhaltensweisen und politische Unternehmerschaft hoher Wissenschaftsbeamter im allgemeinen, und natürlich Althoffs im besonderen.

Als. Ergebnis dieser (neo-institutionellen) ökonomischen Analyse kŏnnen wir festhalten, daß die meisten Maßnahmen, die das Althoff System konstituieren, die Produktivităt des Wissenschaftssystems unter Althoff erhōhten. Aus, dieser Fallstudie lassen sich aber auch Möglichkeiten und vor allem die Grẹnzen bestimmen, die einer aktiven Wissenschaftspolitik gezogen sind. 


\section{Acknowledgements}

It is a pleasure to acknowledge my gratitude to those who have helped me in the course of this dissertation. I am mostly indebted to Jürgen G. Backhaus for creating the rare kind of intellectual environment which young scholars need. I am also grateful to Gerrit Meijer (co-promotor) and Thomas L.C.M. Groot (dissertation committee). Their suggestions were very helpful in improving the manuscript.

Most stimulating were the workshops on Public Policy by William S. Peirce (Case Western Reserve University, Cleveland, Ohio), visiting the University of Limburg during the first year of this research project (1988-1989). I have also benefitted a great deal from the discussions at the weekly Lunch Seminars on Public Economics in Maastricht. I am grateful to all participants.

Very important in the further development of the project were the two conferences on the Althoff system in Germany, where I was able to present my work for a critical audience of historians, economists and administrators of science. The first conference, organized by Jürgen Backhaus and Bernhard vom Brocke (University of Marburg), was held in the Schießhaus in Heilbronn in July 1989. The second took place at the Werner-Reimer-Stiftung in Bad Homburg in May 1990. It was organized by Bernhard vom. Brocke and Peter Krueger (University of Marburg). At the first conference, I received useful comments from Eirik G. Furubotn (University of Arlington-Texas) and Wolfgang Drechsler (University of Marburg). As most Althoff scholars, I am greatly indebted to Bernhard vom Brocke for his meticulous research on the history of the Althoff system.

I also wish to thank the following scholars who gave me their valuable comments on the final manuscript: Gordon Tullock (University of Arizona), Peter Senn (Evanston, Illinois) and William S. Peirce. Bruno S. Frey (University of Zurich) commented with great care on chapter 8 and Daniel S. Hamermesh (Michigan State University) on chapter 2.

A great deal of gratitude I owe to the University of Antwerp (UFSIA), Belgium. I wish to acknowledge the support of the Faculty of Applied Economics, in general, and professor Marcel Van Geel, in particular. 
I am very grateful to the Volkswagenstiftung' and the Werner-Reimer-Stiftung for their financial support, which enabled me to attend the Althoff conferences, and to Georges Span (University of Limburg) for his computer assistance.

Finally, I would like to thank my wife, Yolanda Vansina, for her practical and mental support.

Karl Popper once wrote:

"To avoid' error is a poor ideal. If we dare not to tackle problems which are so complex that error is almost unavoidable, then there will be no growth of knowledge. I.. I Nobody is exempt from making mistakes; the great thing is to learn from them.

I accept full responsibility for the errors that have survived.

Lode Vereeck, October 1992.

- Karl R. Popper (1972), Objective Knowledge: An Evolutionary Approach, Oxford University Press. Oxford, p. 186 . 


\section{Curriculum Vitae}

Lode Vereeck (1965) graduated in 1987 from the University of Antwerp (UFSIA), Belgium, as Licentiate in Applied Economics. While pursuing his doctoral research, he was assistant of Macro-Economics at the Faculty of Applied Economics of UFSIA . In September 1992, he became assistant professor of Law \& Economics at the Faculty of Law, University of Limburg, Maastricht, the Netherlands.

Lode Vereeck (1965) genoot middelbaar onderwijs aan het St.-Lievenscollege te Antwerpen en studeerde toegepaste economische wetenschappen (TEW) aan de Universiteit Antwerpen. (UFSIA). In 1987 studeerde hij af in de oriēntatie publieke economie. Gedurende vijf jaar is hij werkzaam geweest als assistent macro-economie in de faculteit TEW van de UFSIA. Momenteel is hij als universitair docent rechtseconomie verbonden aan de faculteit rechtsgeleerdheid (vakgroep metajuridica) van de Rijksuniversiteit Limburg te Maastricht.

Lode Vereeck (1965) wurde nach dem Studium der Volkswirtschaftslehre und Finanzwissenschaften 1987 Wissenschaftlicher Assistent Makroökonomik an der Fakultăt der Wirtschaftswissenschaften der Universităt Antwerpen (UFSIA), Belgien. Seit September 1992 ist er Universitātsdozent. Rechtsōkonomik an der Fakultăt der Rechtswissenschaften der Universităt Limburg in Maastricht (Niederlande). 
1

ISBN 90-9005735-8 